\title{
\#USES
}

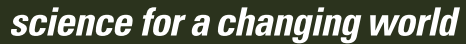

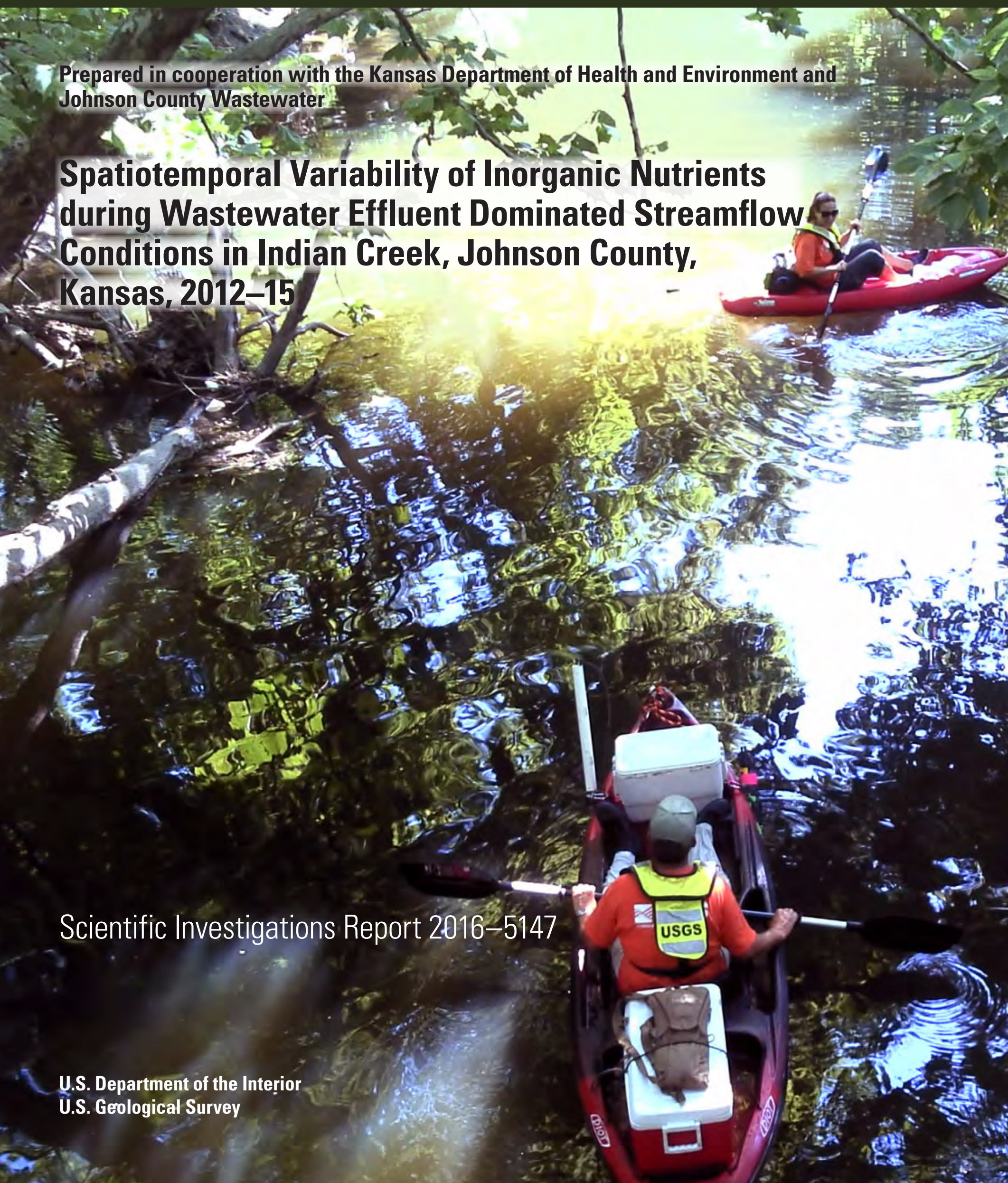


Cover photograph. U.S. Geological Survey hydrologists collecting spatial data on Indian Creek, July 23, 2014 (photograph by J. Gonzalez, U.S. Geological Survey). 


\section{Spatiotemporal Variability of Inorganic Nutrients during Wastewater Effluent Dominated Streamflow Conditions in Indian Creek, Johnson County, Kansas, 2012-15}

By Guy M. Foster, Jennifer L. Graham, Thomas J. Williams, and Lindsey R. King

Prepared in cooperation with the Kansas Department of Health and Environment and Johnson County Wastewater

Scientific Investigations Report 2016-5147 


\title{
U.S. Department of the Interior SALLY JEWELL, Secretary
}

\section{U.S. Geological Survey Suzette M. Kimball, Director}

\author{
U.S. Geological Survey, Reston, Virginia: 2016
}

For more information on the USGS - the Federal source for science about the Earth, its natural and living resources, natural hazards, and the environment—visit http://www.usgs.gov or call 1-888-ASK-USGS.

For an overview of USGS information products, including maps, imagery, and publications, visit http://store.usgs.gov/.

Any use of trade, firm, or product names is for descriptive purposes only and does not imply endorsement by the U.S. Government.

Although this information product, for the most part, is in the public domain, it also may contain copyrighted materials as noted in the text. Permission to reproduce copyrighted items must be secured from the copyright owner.

Suggested citation:

Foster, G.M, Graham, J.L., Williams, T.J., and King, L.R., 2016, Spatiotemporal variability of inorganic nutrients during wastewater effluent dominated streamflow conditions in Indian Creek, Johnson County, Kansas, 2012-15: U.S. Geological Survey Scientific Investigations Report 2016-5147, 37 p., http://dx.doi.org/10.3133/sir20165147.

ISSN 2328-0328 (online) 


\section{Contents}

Abstract
Introduction.
Purpose and Scope
Description of Study Area
Methodss
Spatially Dense Longitudinal Surveys
Sensor-Measured Water-Quality Data at Fixed Sites
$\quad$ Cumulative Difference Analysis
March 2012-June 2013 Sensor-Measured Nitrate Analyses
Nitrate Pulse Analysis

\section{Figures}

1. Map showing study area including wastewater treatment facilities, fixed water-quality monitor sites, and discrete water-quality sample collection sites, Johnson County, Kansas.

2. Photographs showing examples of floating-sensor arrays used for spatially dense data collection.

3. Graphs showing cyclical patterns observed in Indian Creek nitrate plus nitrite concentrations at the 119th, College, and Marty sampling sites, with discrete verification samples and directly in the Middle Basin effluent stream ............................10

4. Graphs showing an example of pulse alignment used for data analysis.........................11

5. Graph showing nitrate plus nitrite concentrations at the fixed College and Marty sites and along the reach between the two fixed sites during May 22 through May 23, 2013, Johnson County, Kansas . 
6. Map and graph showing collected or calculated nitrate plus nitrite data along the study reach on May 23, 2013, Johnson County, Kansas.

7. Graph showing nitrate plus nitrite concentrations at the fixed Middle Basin wastewater treatment facility and Marty sites and along the entire study reach on July 22-24, 2014, Johnson County, Kansas

8. Maps and graphs showing nitrate plus nitrite and orthophosphorus data along the study reach on July 23, 2014, Johnson County, Kansas

9. Map and graph showing nitrate plus nitrite data along the study reach on July 30 , 2015, Johnson County, Kansas....

10. Graph showing nitrate plus nitrite concentrations at the fixed Middle Basin and Marty sites and along the entire study reach from August 23 to 27, 2015, Johnson County, Kansas.

11. Maps and graphs showing nitrate plus nitrite and orthophosphorus data along the study reach on August 26, 2015, Johnson County, Kansas

12. Graphs showing average and standard deviation of nitrate plus nitrite concentration, instantaneous nitrate plus nitrite load, and streamflow at the Indian Creek study sites during March 2012 through June 2013, Johnson County, Kansas

13. Box plots and summary statistics of cyclical variability during a 24-hour period in nitrate plus nitrite concentrations at Indian Creek, Kansas, study sites from March 2012 through June 2013

14. Diagrams showing frequency distribution and differences in nitrate plus nitrite concentrations

15. Graphs showing seasonal average and standard deviation of nitrate plus nitrite data and nitrate plus nitrite concentration differences

\section{Tables}

1. Location and description of Indian Creek Basin study sites in Johnson County, Kansas, including drainage area of the 2011-2013 study sites, and distance from the Middle Basin and Tomahawk Creek wastewater treatment facility effluent discharges

2. Percentage contribution of particulate nitrogen and nitrate plus nitrite to total nitrogen concentrations and particulate phosphorus and orthophosphorus to total phosphorus concentrations during the July 23, 2014, and August 26, 2015, surveys on Indian Creek, Johnson County, Kansas

3. Summary statistics of decrease and percent decrease in maximum nitrate plus nitrite concentrations (as nitrogen) along the Indian Creek, Kansas, reach between College, Marty, and Mission Farms study sites during March 2012 through June 2013 


\section{Conversion Factors}

International System of Units to U.S. customary units

\begin{tabular}{lcl}
\hline \multicolumn{1}{c}{ Multiply } & By & \multicolumn{1}{c}{ To obtain } \\
\hline meter $(\mathrm{m})$ & Length & foot $(\mathrm{ft})$ \\
kilometer $(\mathrm{km})$ & 3.281 & mile $(\mathrm{mi})$ \\
kilometer $(\mathrm{km})$ & 0.6214 & mile, nautical $(\mathrm{nmi})$ \\
\hline & 0.5400 & \\
\hline hectare $(\mathrm{ha})$ & Area & square mile $\left(\mathrm{mi}^{2}\right)$ \\
square kilometer $\left(\mathrm{km}^{2}\right)$ & 0.003861 & square mile $\left(\mathrm{mi}^{2}\right)$ \\
\hline & 0.3861 & gallon $(\mathrm{gal})$ \\
\hline liter $(\mathrm{L})$ & Volume & gallon $(\mathrm{gal})$ \\
cubic meter $\left(\mathrm{m}^{3}\right)$ & 0.2642 & gallon $(\mathrm{gal})$ \\
cubic decimeter $\left(\mathrm{dm}^{3}\right)$ & 264.2 & million gallons $(\mathrm{Mgal})$ \\
cubic meter $\left(\mathrm{m}^{3}\right)$ & 0.2642 & cubic foot $\left(\mathrm{ft}^{3}\right)$ \\
cubic decimeter $\left(\mathrm{dm}^{3}\right)$ & 0.0002642 & cubic foot $\left(\mathrm{ft}^{3}\right)$ \\
cubic meter $\left(\mathrm{m}^{3}\right)$ & 0.03531 & \\
\hline
\end{tabular}

Temperature in degrees Fahrenheit $\left({ }^{\circ} \mathrm{F}\right)$ may be converted to degrees Celsius $\left({ }^{\circ} \mathrm{C}\right)$ as follows: ${ }^{\circ} \mathrm{C}=\left({ }^{\circ} \mathrm{F}-32\right) / 1.8$.

\section{Datum}

Horizontal coordinate information is referenced to the North American Datum of 1983 (NAD 83).

\section{Supplemental Information}

Specific conductance is given in microsiemens per centimeter at 25 degrees Celsius $(\mu \mathrm{S} / \mathrm{cm}$ at $\left.25^{\circ} \mathrm{C}\right)$.

Concentrations of chemical constituents in water are given in either milligrams per liter (mg/L) or micrograms per liter ( $\mu \mathrm{g} / \mathrm{L})$. 



\title{
Spatiotemporal Variability of Inorganic Nutrients During Wastewater Effluent Dominated Streamflow Conditions in Indian Creek, Johnson County, Kansas, 2012-15
}

\author{
By Guy M. Foster, Jennifer L. Graham, Thomas J. Williams, and Lindsey R. King
}

\section{Abstract}

Nutrients, particularly nitrogen and phosphorus, are a leading cause of water-quality impairment in Kansas and the Nation. Indian Creek is one of the most urban drainage basins in Johnson County, Kansas, and environmental and biological conditions are affected by contaminants from point and other urban sources. The Johnson County Douglas L. Smith Middle Basin (hereinafter Middle Basin) wastewater treatment facility (WWTF) is the largest point-source discharge on Indian Creek. A second facility, the Tomahawk Creek WWTF, discharges into Indian Creek approximately 11.6 kilometers downstream from the Middle Basin WWTF. To better characterize the spatiotemporal variability of nutrients in Indian Creek, the U.S. Geological Survey, in cooperation with the Kansas Department of Health and Environment and Johnson County Wastewater, collected high-resolution spatial and temporal (a large number of samples collected over the entire reach or at single locations over a long period of time) inorganic nutrient (nitrate plus nitrite and orthophosphorus) data using a combination of discrete samples and sensor-measured data during 2012 through 2015.

Nutrient patterns observed in Indian Creek along the upstream-downstream gradient during wastewater effluent dominated streamflow conditions were largely affected by the WWTFs and by travel time of the parcels of water. Nitrate plus nitrite concentrations in the Middle Basin WWTF effluent and at downstream sites varied by as much as 6 milligrams per liter over a 24-hour period. The cyclical variability in the Middle Basin WWTF effluent generated a nitrate plus nitrite pulse that could be tracked for approximately 11.5 kilometers downstream in Indian Creek, until the effect was masked by the Tomahawk Creek WWTF effluent discharge. All longitudinal surveys showed the same general patterns along the upstreamdownstream gradient, though streamflows, wastewater effluent contributions to streamflow, and nutrient concentrations spanned a wide range. Differences in orthophosphorus and nitrate plus nitrite patterns were clear along the upstream-downstream gradient in Indian Creek, and orthophosphorus concentrations were not as variable as nitrate plus nitrite concentrations. In general, nitrate plus nitrite concentrations decreased downstream from the Middle Basin WWTF to minima near the confluence with Tomahawk Creek, increased downstream from the Tomahawk Creek WWTF, and then varied little within the study reach. Orthophosphorus concentrations generally decreased downstream from the Middle Basin WWTF.

Despite the marked variability in nitrate plus nitrite concentrations caused by the Middle Basin WWTF effluent discharges, decreases in nitrate plus nitrite concentrations were discernable along the study reach between the two WWTFs. Decreases in nitrate plus nitrite concentrations along study reach were less variable than the cyclical variability typically measured, reiterating the effect of the Middle Basin WWTF effluent discharges on the spatiotemporal variability of nitrate plus nitrite in Indian Creek. Although decreases and rates of change in nitrate plus nitrite concentration were similar between the upper and lower reaches of Indian Creek, relations with initial nitrate plus nitrite concentrations and seasonal patterns were different between the upper (from College to the Marty study sites) and lower reaches (from Marty to the Mission Farms study sites) and did not reflect patterns observed for the overall reach. Quantifying the decreases in nitrate plus nitrite concentration caused by dilution and other in-stream processes were beyond the scope of this study, and were limited by available data. The data that are available suggest that dilution and other in-stream processes play a role in decreasing nitrate plus nitrite concentrations downstream from the Middle Basin WWTF in Indian Creek.

Analysis of the spatiotemporal variability of nutrients focused on below-normal and normal streamflow conditions, when streamflow and nutrient conditions in Indian Creek were largely controlled by WWTF effluent flows and nutrient removal processes. Spatial and temporal data indicate there are decreases in nutrient concentrations along the upstream-downstream gradient in Indian Creek, but quantifying decreases is complicated by the variability in nutrient concentrations caused by the WWTFs. During below-normal and normal streamflow conditions, Indian Creek nutrient concentrations downstream from the Middle Basin WWTF primarily reflect effluent concentrations in the hours or days before depending on relative distance downstream. 


\section{Introduction}

Nutrients, particularly nitrogen and phosphorus, are a leading cause of water-quality impairment in Kansas and the Nation (Kansas Department of Health and Environment, 2004; U.S. Environmental Protection Agency, 2009). The Kansas Surface Water Nutrient Reduction Plan set reduction targets for total nitrogen and phosphorus export from Kansas at 30 percent (Kansas Department of Health and Environment, 2004). Understanding the variability of nitrogen and phosphorus in Kansas streams will help develop effective nutrient reduction strategies, watershed management plans, and best management practices.

Indian Creek (fig. 1) is one of the most urban drainage basins in Johnson County, Kansas, and environmental and biological conditions are affected by contaminants from point and other urban sources (Rasmussen and others, 2009, 2012; Rasmussen and Gatotho, 2014; Graham and others, 2014). The Johnson County Douglas L. Smith Middle Basin (hereinafter Middle Basin) Wastewater Treatment Facility (WWTF) is the largest point-source effluent discharge on Indian Creek (Graham and others, 2014; fig. 1). A second facility, the Tomahawk Creek WWTF, discharges into Indian Creek approximately 11.6 kilometers (km) downstream from the Middle Basin WWTF (fig. 1).

During 2011-13, the U.S. Geological Survey (USGS), in cooperation with Johnson County Wastewater (JCWW), performed a study to assess the effects of wastewater effluent on the environmental and biological conditions of Indian Creek. Two upstream sites were compared to four sites located downstream from the WWTFs using data collected during June 2004 through June 2013 (Graham and others, 2014). Results from that study indicated that wastewater effluent has a substantial effect on nutrient concentrations in Indian Creek. Nitrogen and phosphorus concentrations downstream from the WWTFs were 10- to 100-times higher than at the upstream sites during below-normal and normal streamflow conditions. Along the upstream-downstream gradient, nitrogen and phosphorus concentrations were elevated immediately downstream from the Middle Basin WWTF, and decreased with increasing distance downstream until reaching the Tomahawk Creek WWTF (Graham and others, 2014). Although broad changes in nutrient concentrations along the upstream-downstream gradient were characterized by the Graham and others (2014) study, spatial data were limited to six sites. Optical sensors were used to measure nitrate plus nitrite every 15 minutes during March 2012 through June 2013; however, temporal variability was not evaluated by Graham and others (2014).

To better characterize the spatiotemporal variability of nutrients in Indian Creek, the USGS, in cooperation with the Kansas Department of Health and Environment (KDHE) and JCWW, collected high-resolution spatial data using a combination of discrete samples and sensor-measured data from 2013 through 2015. These spatial data provided insights into nutrient transport downstream from the Middle Basin WWTF, and allowed a more comprehensive analysis of the sensormeasured nitrate plus nitrite data collected from March 2012 through June 2013.

\section{Purpose and Scope}

The purpose of this report is to describe inorganic nutrient (nitrate plus nitrite and orthophosphorus) variability in Indian Creek, Johnson County, Kansas, using spatially and temporally dense data collected from March 2012 through August 2015. Two intensive spatial studies performed during summers 2014 and 2015 included sensor-measured nitrate plus nitrite and collection of discrete orthophosphorus samples. Two additional spatial studies in 2013 and 2015 collected sensor-measured nitrate plus nitrite data. Sensormeasured nitrate plus nitrite data collected every 15 minutes during March 2012 through June 2013 were used to describe spatial and temporal (cyclical and seasonal) variability in concentrations. The high-resolution spatial data provided insight about the effect of the Middle Basin WWTF on Indian Creek nitrate plus nitrite concentrations and informed the analysis of the high-resolution temporal data collected during March 2012 through June 2013. Study results provide insight into the variability of nitrate plus nitrite concentrations and orthophosphorus concentrations in an urban, wastewater effluent dominated stream, and study results improve understanding of the effect of point-source discharges on water quality in urban areas.

\section{Description of Study Area}

The Indian Creek drainage basin is 194 square kilometers $\left(\mathrm{km}^{2}\right)$ and includes parts of Johnson County, Kansas, and Jackson County, Missouri (not shown). About 86 percent of the Indian Creek drainage basin is located in Johnson County, Kansas. Indian Creek flows east from its headwaters in central Johnson County, Kansas, to the Blue River, approximately 3.5 river miles downstream of State Line. Overall, 93 percent of land use in the Indian Creek drainage basin is classified as urban and 47 percent is classified as impervious surface (Graham and others, 2014). Recreational areas, including golf courses and streamway parks, border much of Indian Creek (fig. 1).

Two WWTFs, Middle Basin and Tomahawk Creek, discharge into Indian Creek within Johnson County, Kansas (fig. 1). The Middle Basin WWTF originally was constructed in the 1950s as a facultative lagoon plant and has undergone numerous upgrades to increase capacity and improve technology. The most recent (2007-10) upgrades increased design capacity from 18.6 cubic feet per second $\left(\mathrm{ft}^{3} / \mathrm{s}\right)$ to $22.4 \mathrm{ft}^{3} / \mathrm{s}$ (12 to 14.5 million gallons per day) and added a biological nutrient removal activated sludge system. The Tomahawk Creek WWTF, originally constructed in 1955, is a trickling filter plant and has a design capacity of $15.5 \mathrm{ft}^{3} / \mathrm{s}$ (10 million gallons per day; Susan Pekarek, Johnson County Wastewater, written commun., 2013).

The spatiotemporal variability of nutrients in Indian Creek was characterized using a combination of 


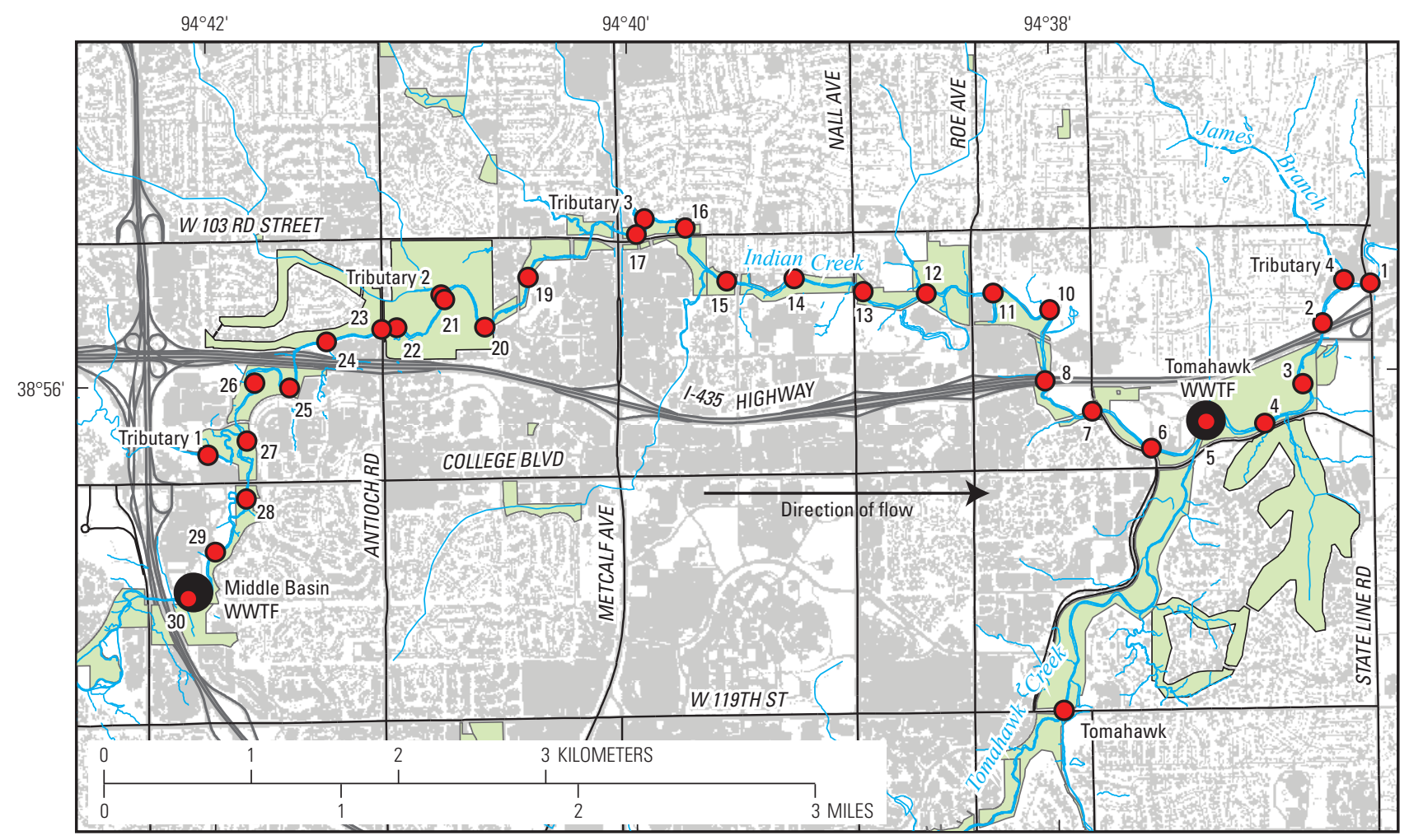

Base from Automated Information Mapping Systems, 2015
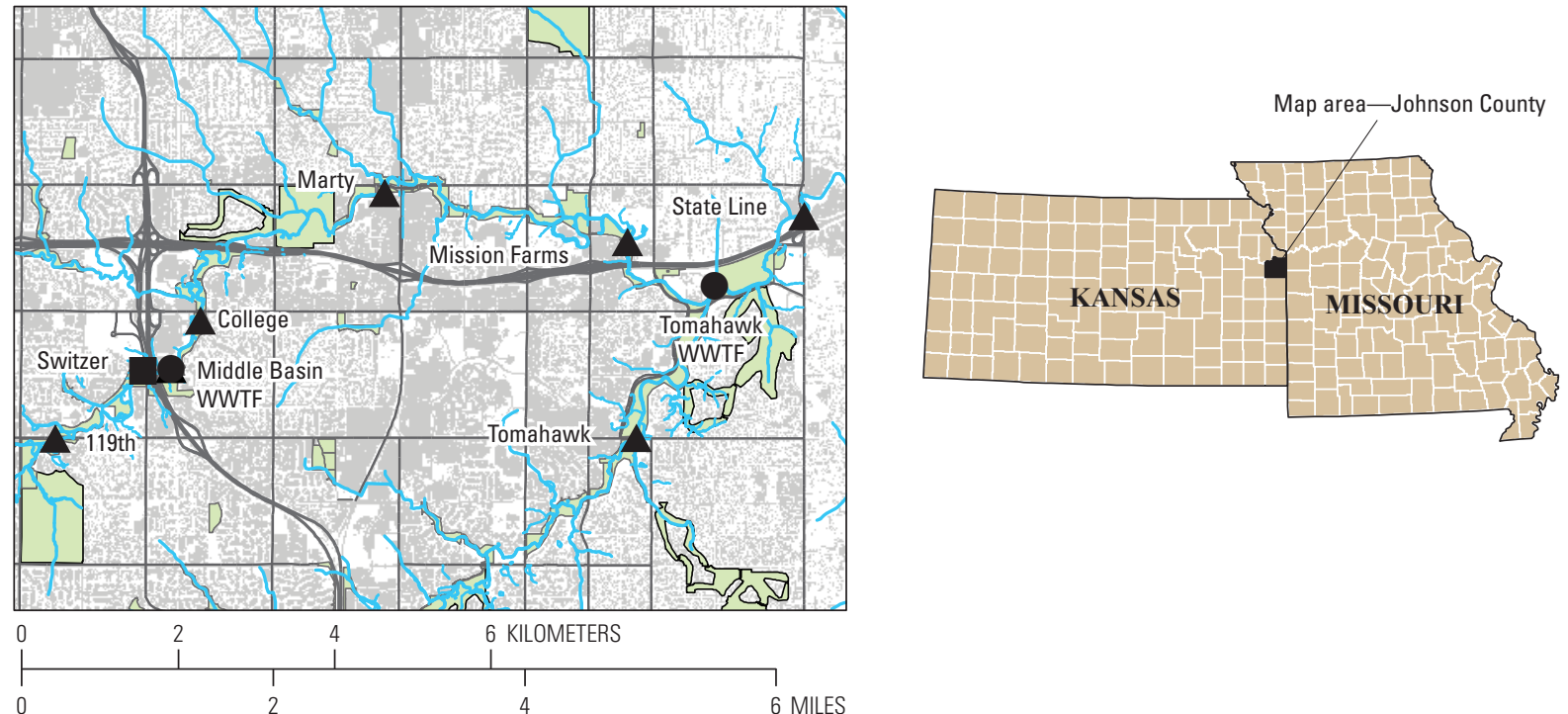

EXPLANATION

[Refer to table 1 for site descriptions]

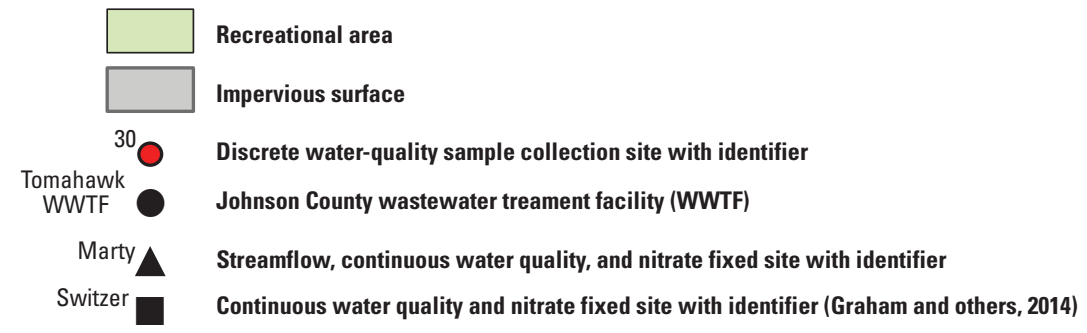

Figure 1. Study area including wastewater treatment facilities, fixed water-quality monitor sites, and discrete water-quality sample collection sites, Johnson County, Kansas. 
floating-sensor arrays, discrete samples, and fixed-site sensors along a 16-km reach of Indian Creek, at the two WWTFs, at Tomahawk Creek (a large tributary), and at four smaller tributary sites (fig. 1, table 1). Six of the study sites were included in the 2011-13 study performed by Graham and others (2014), and serve as a frame of reference for all other sites included in the current (2016) study. Five of the 2011-13 study sites were located on Indian Creek and one site was located on Tomahawk Creek, the largest tributary to Indian Creek. The 119th and Tomahawk Creek sites were located upstream from the Middle Basin and Tomahawk Creek WWTF effluent discharges; all other sites were affected by wastewater effluent. The College, Marty, and Mission Farms sites are located 1.1, 5.5 , and $9.8 \mathrm{~km}$, respectively, downstream from the Middle Basin WWTF effluent discharge. The State Line site is located $13.6 \mathrm{~km}$ downstream from the Middle Basin WWTF effluent discharge and $2.0 \mathrm{~km}$ downstream from the Tomahawk Creek WWTF effluent discharge (fig. 1, table 1).

\section{Methods}

Four spatially dense longitudinal surveys were performed on Indian Creek during 2013-15, and included a combination of floating-sensor arrays, discrete sample collection, and fixedsite sensors to describe spatial variability along the upstreamdownstream gradient. During July 23, 2014 and August 26, 2015 , nitrate plus nitrite and other water-quality parameters were measured at two or three fixed sites (Switzer, Middle Basin WWTF, and Marty; fig. 1, table 1) to provide insights into downstream nutrient transport and temporal analysis. Previously collected streamflow and nitrate plus nitrite data at six fixed sites (fig. 1) on Indian Creek and Tomahawk Creek (119th, College, Marty, Mission Farms, Tomahawk, and State Line) during March 2012 through June 2013 were used to describe spatial and temporal (cyclical and seasonal) variability in concentrations along the upstream-downstream gradient. Methods used to measure previously collected streamflow and nitrate plus nitrite data are described in Graham and others (2014). All data collected as part of this study and by Graham and others (2014) are available through the USGS National Water Information System (NWIS) at http://dx.doi. org/10.5066/F7P55KJN and in King and others (2016a, b).

\section{Spatially Dense Longitudinal Surveys}

Spatially dense longitudinal surveys collected sensormeasured water-quality data on May 23, 2013 and July 30,2015 at normal or slightly above-normal streamflow conditions using a floating-sensor array (fig. 2). Spatially dense longitudinal surveys performed on July 23, 2014, and August 26, 2015, collected sensor-measured water-quality data using a floating-sensor array at fixed sites, as well as discrete nutrient samples (every 0.5 or $1.0 \mathrm{~km}$; fig. 1) during belownormal streamflow conditions. Streamflow was measured and discrete water-quality samples were collected at five tributary sites during the 2014 and August 2015 surveys. Periphyton and streambed sediment data were collected every $1.0 \mathrm{~km}$ during the 2014 survey following the methods described in Graham and others (2014). The periphyton and streambed sediment data did not substantially add to this analysis or interpretation, but are available through NWIS at http://dx.doi. org/10.5066/F7P55KJN. The May 23, 2013, survey was a pilot performed on a 3.4-km reach starting at the College site and ending short of the Marty site. The other three surveys were performed on a 13.2-km reach of Indian Creek starting approximately $0.4 \mathrm{~km}$ upstream of the Middle Basin WWTF and ending at State Line site.

\section{Spatially Dense Water-Quality Data Collection}

Multiparameter water-quality monitors (YSI EXO2; Yellow Springs Instruments, 2014) measured temperature, specific conductance, turbidity, $\mathrm{pH}$, and dissolved oxygen at 30 -second intervals. These water-quality data did not substantially add to this analysis or interpretation, but are available in King and others (2016a, b). Optical nitrate sensors (Hach Nitratax plus sc, $5 \mathrm{~mm}$ ) measured at 30 -second intervals. The nitrate sensor does not differentiate between nitrate and nitrite; therefore, all reported concentrations include nitrate plus nitrite (Pellerin and others, 2013). For simplicity, nitrate is used throughout the report to refer to the sensor-measured data. All sensors were mounted to floating platforms, either a custom boogie board (2013 survey; fig. $2 A$ ) or kayaks (2014 and 2015 surveys; fig. $2 B$ ), at approximately 0.3 meters (m) below the water surface. Care was taken to minimize disturbance of bottom sediments during data collection when using the floating-sensor platforms. All sensors were calibrated before each deployment in accordance with USGS protocols (U.S. Geological Survey, variously dated; Pellerin and others, 2013) and manufacturer's guidelines (Yellow Springs Instruments, 2014). The locations of the floating platforms were recorded every 30 seconds using a global positioning system (GPS; Garmin Montana 650T). All data loggers had their time synchronized at the beginning of collection events. Sensormeasured data were reviewed and erroneous spikes were deleted before analysis and interpretation.

\section{Discrete Nutrient Samples}

Water samples for nutrient (nitrogen and phosphorus) analyses were collected at 0.5 or $1.0-\mathrm{km}$ intervals along Indian Creek from Switzer to State Line sampling sites, the Middle Basin and Tomahawk Creek WWTF effluent discharges, and five tributary streams (Tributaries 1-4 and Tomahawk Creek; fig. 1) during the July 23, 2014, and August 26, 2015 , surveys. In 2014, samples in shallow water (less than $0.5 \mathrm{~m}$ ) were collected by surface grab. Samples in water deeper than $0.5 \mathrm{~m}$ were collected using a depth integrated sampler (DH81). Samples either were collected directly into sample bottles 
Table 1. Location and description of Indian Creek Basin study sites in Johnson County, Kansas, including drainage area of the 2011-2013 study sites, and distance from the Middle Basin and Tomahawk Creek wastewater treatment facility effluent discharges.

[km², square kilometer; km, kilometer; *, fixed site; C, Creek; KS, Kansas; N, north; W, west; --, no data; nr, near; WWTP, wasterwater treatment plant; Co, county; Trib, tributary; mi, mile; E, east; Hwy, highway; Blvd, boulevard; St, street; Rd, road; Dr, drive; Ave, avenue; Pkwy, parkway]

\begin{tabular}{|c|c|c|c|c|c|c|c|c|}
\hline \multicolumn{5}{|c|}{ Site description } & \multirow{2}{*}{$\begin{array}{c}\text { Drainage } \\
\text { area } \\
\left(\mathbf{k m}^{2}\right)\end{array}$} & \multirow{2}{*}{$\begin{array}{l}\text { Distance from Middle } \\
\text { Basin wastewater treat- } \\
\text { ment facility discharge } \\
(\mathbf{k m})\end{array}$} & \multirow{2}{*}{$\begin{array}{c}\text { Distance from } \\
\text { Tomahawk Creek waste- } \\
\text { water treatment facility } \\
\text { discharge } \\
(\mathbf{k m})\end{array}$} & \multirow{2}{*}{$\begin{array}{c}\text { Timeframe of continuous } \\
\text { water-quality monitor } \\
\text { operation }\end{array}$} \\
\hline Site Identifier & Site name & $\begin{array}{l}\text { U.S. Geological Survey } \\
\text { station number }\end{array}$ & Latitude & Longtiude & & & & \\
\hline$* 119$ th & Indian C at 119th Street, Overland Park, KS & 385446094430700 & $38^{\circ} 54^{\prime} 46^{\prime \prime} \mathrm{N}$ & $94^{\circ} 43^{\prime} 07^{\prime \prime} \mathrm{W}$ & 36.9 & 2.4 upstream & 13.00 & June 8, 2011-July 9, 2013 \\
\hline *Switzer & Indian $\mathrm{C}$ at Hwy 69, Overland Park, KS & 06893270 & $38^{\circ} 55^{\prime} 14.07^{\prime} \mathrm{N}$ & $94^{\circ} 42^{\prime} 20.02^{\prime} \mathrm{W}$ & -- & 0.42 & 11.87 & $\begin{array}{l}\text { July } 22,2014-J u l y ~ 25 \text {, } \\
\quad 2014\end{array}$ \\
\hline 30 & Indian C nr Middle Basin WWTP, Johnson Co, KS & 385514094420800 & $38^{\circ} 55^{\prime} 13.56^{\prime \prime} \mathrm{N}$ & $94^{\circ} 42^{\prime} 6.65^{\prime \prime} \mathrm{W}$ & -- & 0.10 & 11.55 & -- \\
\hline *Middle Basin Effluent & $\begin{array}{l}\text { Indian C Trib nr Middle Basin WWTP, Overland } \\
\text { Park, KS }\end{array}$ & 385515094420500 & $38^{\circ} 55^{\prime} 15.09^{\prime} \mathrm{N}$ & $94^{\circ} 42^{\prime} 5.30^{\prime \prime} \mathrm{W}$ & -- & 0.00 & 11.57 & $\begin{array}{l}\text { July 22, 2014-July 25, } \\
\text { 2014; August 21-27, } \\
2015\end{array}$ \\
\hline 29 & Indian C $0.25 \mathrm{mi} \mathrm{E}$ of Hwy 69, Overland Park, KS & 385524094415900 & $38^{\circ} 55^{\prime} 23.63^{\prime \prime} \mathrm{N}$ & $94^{\circ} 41^{\prime} 58.90^{\prime \prime W}$ & -- & 0.53 & 11.04 & -- \\
\hline *College (28) & Indian $\mathrm{C}$ at College Blvd, Overland Park, KS & 385520094420000 & $38^{\circ} 55^{\prime} 35.23^{\prime \prime} \mathrm{N}$ & $94^{\circ} 41^{\prime} 49.69^{\prime \prime} \mathrm{W}$ & 40.9 & 1.06 & 10.51 & $\begin{array}{l}\text { May 17, 2011-July 9, } \\
2013\end{array}$ \\
\hline 27 & Indian C nr Mastin St, Overland Park, KS & 385548094414900 & $38^{\circ} 55^{\prime} 47.88^{\prime} \mathrm{N}$ & $94^{\circ} 41^{\prime} 49.40^{\prime} \mathrm{W}$ & -- & 1.47 & 10.10 & -- \\
\hline Tributary 1 & Indian C Trib nr W 109th St, Overland Park, KS & 385545094420100 & $38^{\circ} 55^{\prime} 44.82^{\prime} \mathrm{N}$ & $94^{\circ} 42^{\prime} 0.54^{\prime} \mathrm{W}$ & -- & -- & -- & -- \\
\hline 26 & Indian C nr Farley St, Overland Park, KS & 385600094414700 & $38^{\circ} 56^{\prime} 0.41^{\prime \prime} \mathrm{N}$ & $94^{\circ} 41^{\prime} 46.96^{\prime \prime} \mathrm{W}$ & -- & 1.97 & 9.60 & -- \\
\hline 25 & Indian C nr 109th St, Overland Park, KS & 385559094413700 & $38^{\circ} 55^{\prime} 59.28^{\prime} \mathrm{N}$ & $94^{\circ} 41^{\prime} 36.94^{\prime} \mathrm{W}$ & -- & 2.47 & 9.10 & -- \\
\hline 24 & Indian C nr 106th Terrace, Overland Park, KS & 385609094412600 & $38^{\circ} 56^{\prime} 9.21^{\prime \prime} \mathrm{N}$ & $94^{\circ} 41^{\prime} 26.29^{\prime \prime} \mathrm{W}$ & -- & 2.97 & 8.60 & -- \\
\hline 23 & Indian $\mathrm{C}$ at Antioch Rd, Overland Park, KS & 385613094411100 & $38^{\circ} 56^{\prime} 11.70^{\prime \prime} \mathrm{N}$ & $94^{\circ} 41^{\prime} 10.53^{\prime} \mathrm{W}$ & -- & 3.38 & 8.19 & -- \\
\hline 22 & Indian C nr Antioch Rd, Overland Park, KS & 385612094410600 & $38^{\circ} 56^{\prime} 12.04^{\prime \prime} \mathrm{N}$ & $94^{\circ} 41^{\prime} 6.32^{\prime \prime} \mathrm{W}$ & -- & 3.48 & 8.09 & -- \\
\hline 21 & Indian C $0.25 \mathrm{mi} \mathrm{N}$ of Hwy 50, Overland Park, KS & 385618094405300 & $38^{\circ} 56^{\prime} 18.10^{\prime \prime} \mathrm{N}$ & $94^{\circ} 40^{\prime} 52.70^{\prime} \mathrm{W}$ & -- & 3.97 & 7.60 & -- \\
\hline Tributary 2 & Indian C Trib nr Antioch Rd, Overland Park, KS & 385619094405400 & $38^{\circ} 56^{\prime} 19.09^{\prime} \mathrm{N}$ & $94^{\circ} 40^{\prime} 53.61^{\prime} \mathrm{W}$ & -- & -- & -- & -- \\
\hline 20 & Indian C nr Country Club Dr, Overland Park, KS & 385612094404100 & $38^{\circ} 56^{\prime} 11.96^{\prime \prime} \mathrm{N}$ & $94^{\circ} 40^{\prime} 41.26^{\prime} \mathrm{W}$ & -- & 4.48 & 7.09 & -- \\
\hline 19 & Indian C nr Conser St, Overland Park, KS & 385623094402900 & $38^{\circ} 56^{\prime} 22.72 ” \mathrm{~N}$ & $94^{\circ} 40^{\prime} 28.78^{\prime \prime} \mathrm{W}$ & -- & 5.00 & 6.57 & -- \\
\hline *Marty (18) & Indian $\mathrm{C}$ at Overland Park, $\mathrm{KS}$ & 06893300 & $38^{\circ} 56^{\prime} 28.23^{\prime} \mathrm{N}$ & $94^{\circ} 40^{\prime} 11.98^{\prime} \mathrm{W}$ & 68.9 & 5.51 & 6.06 & $\begin{array}{l}\text { May 18, 2011-July 9, } \\
\text { 2013; July 22-25, } \\
\text { 2014; August 23-27, } \\
2015\end{array}$ \\
\hline 17 & Indian C nr Metcalf Ave, Overland Park, KS & 385632094395800 & $38^{\circ} 56^{\prime} 31.644^{\prime \prime}$ & $94^{\circ} 39^{\prime} 57.73^{\prime \prime W}$ & -- & 6.03 & 5.54 & -- \\
\hline Tributary 3 & Indian C Trib nr Metcalf Ave, Overland Park, KS & 385635094395500 & $38^{\circ} 56^{\prime} 35.09^{\prime \prime} \mathrm{N}$ & $94^{\circ} 39^{\prime} 55.44^{\prime} \mathrm{W}$ & -- & -- & -- & -- \\
\hline 16 & Indian C nr 103rd St, Overland Park, KS & 385633094394400 & $38^{\circ} 56^{\prime} 32.94^{\prime \prime} \mathrm{N}$ & $94^{\circ} 39^{\prime} 43.74^{\prime \prime W}$ & -- & 6.53 & 5.04 & -- \\
\hline 15 & Indian C nr Lamar Ave, Overland Park, KS & 385621094393200 & $38^{\circ} 56^{\prime} 21.16^{\prime \prime N}$ & $94^{\circ} 39^{\prime} 32.10^{\prime \prime W}$ & -- & 7.03 & 4.54 & -- \\
\hline 14 & Indian C nr Indian C Dr, Overland Park, KS & 385622094391300 & $38^{\circ} 56^{\prime} 21.69^{\prime \prime} \mathrm{N}$ & $94^{\circ} 39^{\prime} 13.01^{\prime \prime W}$ & -- & 7.54 & 4.03 & -- \\
\hline 13 & Indian $\mathrm{C}$ at Nall Ave, Overland Park, KS & 385620094385700 & $38^{\circ} 56^{\prime} 18.58^{\prime \prime} \mathrm{N}$ & $94^{\circ} 38^{\prime} 53.47^{\prime \prime W}$ & -- & 8.04 & 3.53 & -- \\
\hline 12 & Indian C $0.02 \mathrm{mi} \mathrm{W}$ of Roe Ave, Overland Park, KS & 385618094383500 & $38^{\circ} 56^{\prime} 17.89^{\prime \prime} \mathrm{N}$ & $94^{\circ} 38^{\prime} 35.36^{\prime \prime W}$ & -- & 8.55 & 3.02 & -- \\
\hline 11 & Indian C nr Roe Ave, Overland Park, KS & 385618094381700 & $38^{\circ} 56^{\prime} 17.84^{\prime} \mathrm{N}$ & $94^{\circ} 38^{\prime} 16.50^{\prime} \mathrm{W}$ & -- & 9.04 & 2.53 & -- \\
\hline
\end{tabular}


Table 1. Location and description of Indian Creek Basin study sites in Johnson County, Kansas, including drainage area of the 2011-2013 study sites, and distance from the Middle Basin and Tomahawk Creek wastewater treatment facility effluent discharges.-Continued

$\left[\mathrm{km}^{2}\right.$, square kilometer; km, kilometer; *, fixed site; C, Creek; KS, Kansas; N, north; W, west; --, no data; nr, near; WWTP, wasterwater treatment plant; Co, county; Trib, tributary; mi, mile; E, east; Hwy, highway; Blvd, boulevard; St, street; Rd, road; Dr, drive; Ave, avenue; Pkwy, parkway]

\begin{tabular}{|c|c|c|c|c|c|c|c|c|}
\hline \multicolumn{5}{|c|}{ Site description } & \multirow[b]{2}{*}{$\begin{array}{c}\text { Drainage } \\
\text { area } \\
\left(\mathbf{k m}^{2}\right)\end{array}$} & \multirow{2}{*}{$\begin{array}{l}\text { Distance from Middle } \\
\text { Basin wastewater treat- } \\
\text { ment facility discharge } \\
(\mathbf{k m})\end{array}$} & \multirow{2}{*}{$\begin{array}{c}\text { Distance from } \\
\text { Tomahawk Creek waste- } \\
\text { water treatment facility } \\
\text { discharge } \\
(\mathbf{k m})\end{array}$} & \multirow{2}{*}{$\begin{array}{l}\text { Timeframe of continuous } \\
\text { water-quality monitor } \\
\text { operation }\end{array}$} \\
\hline Site Identifier & Site name & $\begin{array}{l}\text { U.S. Geological Survey } \\
\text { station number }\end{array}$ & Latitude & Longtiude & & & & \\
\hline 10 & Indian C nr 105th St, Overland Park, KS & 385614094380000 & $38^{\circ} 56^{\prime} 14.04^{\prime \prime} \mathrm{N}$ & $94^{\circ} 38^{\prime} 0.35^{\prime \prime} \mathrm{W}$ & -- & 9.55 & 2.02 & -- \\
\hline *Mission Farms (9) & Indian C at Indian C Pkwy, Overland Park, KS & 385608094380300 & $38^{\circ} 56^{\prime} 8.14^{\prime \prime} \mathrm{N}$ & $94^{\circ} 38^{\prime} 2.95^{\prime \prime} \mathrm{W}$ & 94.8 & 9.75 & 1.82 & $\begin{array}{l}\text { May 17, 2011-July 10, } \\
\text { 2013; August 24-27, } \\
2015\end{array}$ \\
\hline 8 & Indian $\mathrm{C}$ at Hwy 50, Overland Park, KS & 385559094380200 & $38^{\circ} 55^{\prime} 58.56^{\prime \prime} \mathrm{N}$ & $94^{\circ} 38^{\prime} 1.94^{\prime \prime} \mathrm{W}$ & -- & 10.05 & 1.52 & -- \\
\hline 7 & Indian C nr 110th St, Leawood, KS & 385552094374900 & $38^{\circ} 55^{\prime} 51.72^{\prime} \mathrm{N}$ & $94^{\circ} 37^{\prime} 48.66^{\prime} \mathrm{W}$ & -- & 10.55 & 1.02 & -- \\
\hline 6 & Indian C nr Mission Rd, Leawood, KS & 385544094373200 & $38^{\circ} 55^{\prime} 43.50^{\prime} \mathrm{N}$ & $94^{\circ} 37^{\prime} 32.07^{\prime \prime} \mathrm{W}$ & -- & 11.06 & 0.51 & -- \\
\hline Tomahawk Effluent & Indian C nr Tomahawk Effluent, Leawood, KS & 385550094371700 & $38^{\circ} 55^{\prime} 49.51^{\prime \prime} \mathrm{N}$ & $94^{\circ} 37^{\prime} 16.51^{\prime \prime} \mathrm{W}$ & -- & 11.57 & 0.00 & -- \\
\hline *Tomahawk & Tomahawk C nr Overland Park, KS & 06893350 & $38^{\circ} 54^{\prime} 46.62^{\prime} \mathrm{N}$ & $94^{\circ} 37^{\prime} 57.96^{\prime \prime} \mathrm{W}$ & 61.9 & -- & -- & $\begin{array}{l}\text { May 17, 2011-August } \\
\quad 4,2013\end{array}$ \\
\hline 5 & Indian C $0.05 \mathrm{mi} \mathrm{N}$ of College Blvd, Leawood, KS & 385549094371600 & $38^{\circ} 55^{\prime} 49.07^{\prime \prime} \mathrm{N}$ & $94^{\circ} 37^{\prime} 16.30^{\prime \prime} \mathrm{W}$ & -- & 11.57 & 0.00 & -- \\
\hline 4 & Indian C nr Brookwood Ave, Leawood, KS & 385549094364900 & $38^{\circ} 55^{\prime} 48.52^{\prime} \mathrm{N}$ & $94^{\circ} 36^{\prime} 59.65^{\prime \prime} \mathrm{W}$ & -- & 12.08 & 0.51 & -- \\
\hline 3 & Indian C nr Lee Blvd, Leawood, KS & 385557094364900 & $38^{\circ} 55^{\prime} 57.05^{\prime} \mathrm{N}$ & $94^{\circ} 36^{\prime} 48.69^{\prime \prime} \mathrm{W}$ & -- & 12.59 & 1.02 & -- \\
\hline 2 & Indian C nr Hwy 50, Leawood, KS & 385610094364300 & $38^{\circ} 56^{\prime} 10.25^{\prime} \mathrm{N}$ & $94^{\circ} 36^{\prime} 42.82^{\prime \prime} \mathrm{W}$ & -- & 13.10 & 1.53 & -- \\
\hline Tributary 4 & Indian C Trib nr W 104 St, Leawood, KS & 385620094363700 & $38^{\circ} 56^{\prime} 19.68^{\prime \prime} \mathrm{N}$ & $94^{\circ} 36^{\prime} 36.60^{\prime \prime} \mathrm{W}$ & -- & -- & -- & -- \\
\hline *State Line (1) & Indian $\mathrm{C}$ at State Line Rd, Leawood, KS & 06893390 & $38^{\circ} 56^{\prime} 18.87^{\prime} \mathrm{N}$ & $94^{\circ} 36^{\prime} 29.12^{\prime \prime} \mathrm{W}$ & 166 & 13.60 & 2.03 & $\begin{array}{l}\text { October 1, 2007-July } 15 \text {, } \\
\quad 2015\end{array}$ \\
\hline
\end{tabular}



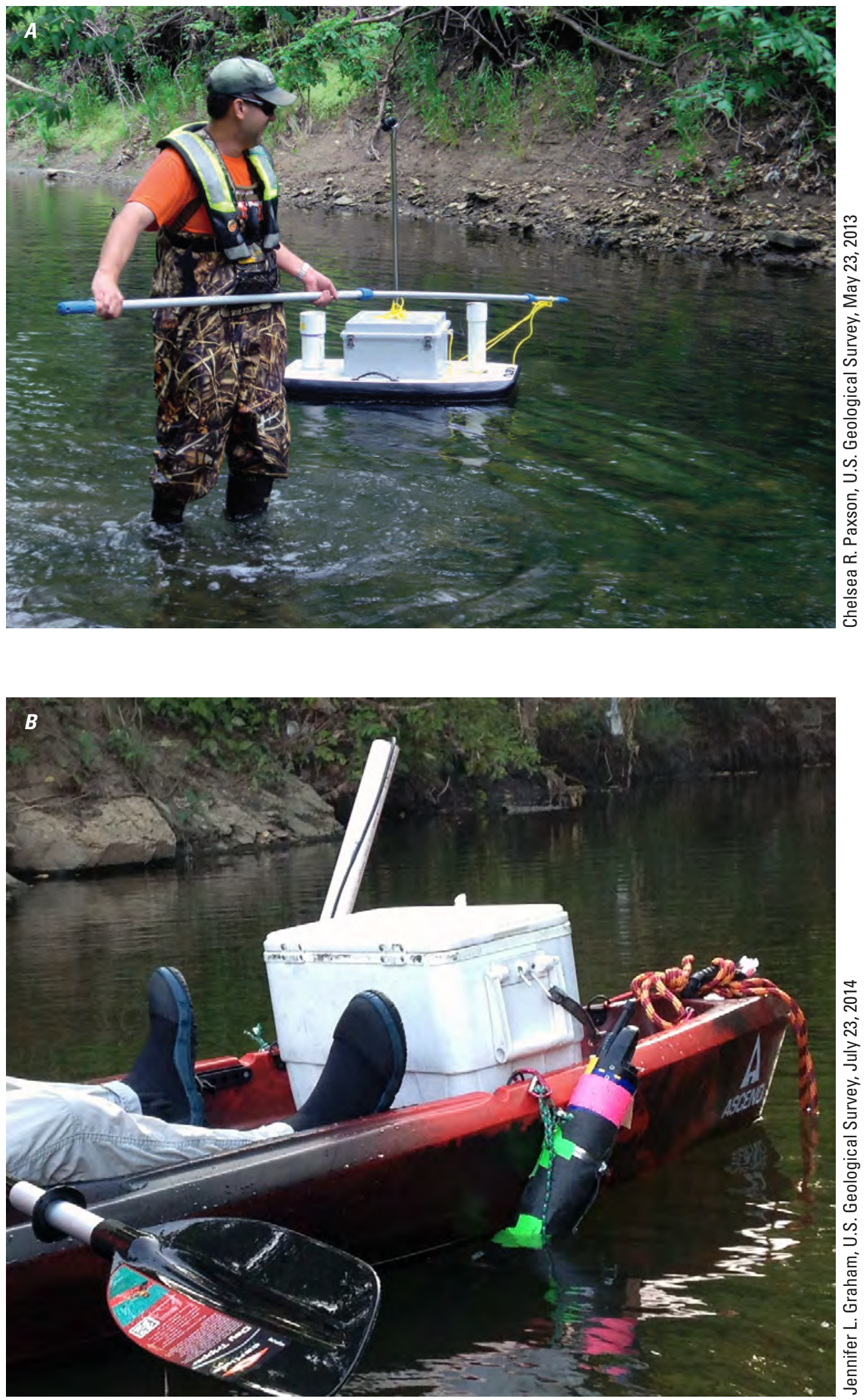

Figure 2. Examples of floating-sensor arrays used for spatially dense data collection $A$, experimental "boogie board" used on May 23, 2013, and B, kayak-mounted sensors. 
(surface grabs) or into 1-liter Teflon sample bottles (depth integrated) at the centroid of flow. In 2015, all samples were collected by surface grab at the centroid of flow. Nutrient samples were processed and analyzed by the Johnson County Wastewater Water-Quality Laboratory according to Standard Methods (American Public Health Association and others, 2005).

The Johnson County Wastewater Water-Quality Laboratory is National Environmental Laboratory Accreditation Conference (NELAC) accredited and routinely participates in standard references sample evaluations. Analysis and interpretation for this report focuses on nitrate plus nitrite and orthophosphorus data; however, all nutrient data are available through NWIS at http://dx.doi.org/10.5066/F7P55KJN.

Quality-assurance and quality-control (QA/QC) samples were collected to evaluate variability in sample collection and processing techniques. About 13 percent of discrete water-quality samples were QA/QC samples during each spatial survey. Five concurrent replicate pairs were collected during the July 23, 2014, survey, and six pairs were collected during the August 26, 2015, survey. Relative percentage difference (RPD) was used to evaluate differences in analyte concentrations detected in replicate water samples. The RPD was calculated by dividing the difference between replicate pairs by the mean and multiplying that value by 100 , thereby creating a value that represents the percent difference between replicate samples (Zar, 1999). Most replicate pairs of nitrate plus nitrite had RPDs that were less than or equal to 5 percent. One replicate pair had an RPD of 11 percent; however, concentrations in these samples were low ( 0.33 and 0.37 milligrams per liter $[\mathrm{mg} / \mathrm{L}]$ as nitrogen). All replicate pairs of orthophosphorus had RPDs that were less than or equal to 2 percent.

\section{Sensor-Measured Water-Quality Data at Fixed Sites}

Nitrate sensors and other water-quality instrumentation deployed during the 2011-13 study were removed at the end of June 2013. Temporary fixed sites were installed at Switzer (2014 only), Middle Basin, and Marty during the July 2014 and August 2015 surveys (fig. 1). Optical nitrate sensors (Hach Nitratax plus sc, 5 millimeters) measured nitrate concentrations at 15-minute intervals. Multiparameter water-quality monitors (YSI EXO2; Yellow Springs Instruments, 2014) measured temperature, specific conductance, turbidity, $\mathrm{pH}$, and dissolved oxygen at 15-minute intervals. All sensors were calibrated before each deployment in accordance with USGS protocols (U.S. Geological Survey, variously dated; Pellerin and others, 2013) and manufacturer's guidelines (Yellow Springs Instruments, 2014). Data were quality assured using guidelines detailed in Wagner and others (2006). The temperature, specific conductance, turbidity, $\mathrm{pH}$, dissolved oxygen data did not substantially add to this analysis or interpretation, but are available in King and others (2016a, b).

\section{Streamflow}

Streamflow has been measured at the Marty site since 1963 and the State Line site since 2003 using standard USGS methods (Sauer and Turnipseed, 2010; Turnipseed and Sauer, 2010). Data from these sites were used to describe Indian Creek streamflow conditions during the four longitudinal surveys. The Middle Basin and Tomahawk Creek WWTFs keep a daily record of wastewater effluent discharge volume and were obtained from JCWW for the time period surrounding each of the longitudinal surveys (Doug Nolkemper, Johnson County Wastewater, written commun., 2013, 2014, and 2015). Wastewater effluent contributions to streamflow were estimated using daily effluent discharge volume and daily mean streamflows.

Several tributary streams contribute to Indian Creek (fig. 1). For measuring tributary contributions to streamflow in Indian Creek, discharge was measured at five tributary streams (tributaries 1-4 and Tomahawk Creek; table 1; fig. 1) during the July 23, 2014, and August 26, 2015, surveys. Tributary discharge was measured using a Flowtracker acoustic velocity meter (AVM) as described in Turnipseed and Sauer (2010). Tributary streamflow measurements were rated from "fair" ( 5 to 8 percent uncertainty) to "poor" (greater than 8 percent) based on USGS measurement standards (Turnipseed and Sauer, 2010). When analyzing the maximum contribution of tributary streamflow to Indian Creek, the maximum uncertainty error value was used for fair measurements (8 percent), and an error value of 15 percent was selected for poor measurements. The selection of 15 percent seemed a reasonable value for the "greater than 8 percent" standard, however this value was arbitrary. Tributaries with no streamflow were not assigned an uncertainty rating. All streamflow data are available through NWIS at http://dx.doi.org/10.5066/F7P55KJN.

\section{Data Analysis}

Most of the analyses include only data collected at below-normal and normal streamflow conditions, when wastewater effluent dominated streamflows. Below-normal, normal, and above-normal streamflow conditions were defined in Graham and others (2014) using the USGS WaterWatch Website percentile class breaks (U.S. Geological Survey, 2014). Below-normal (less than 25th percentile) and normal (25th to 75th percentile) streamflow conditions were chosen for this study because they best represent WWTF effluent-dominated conditions (Graham and others, 2014) when the effect of tributaries is minimal.

Nutrient analysis focuses on nitrate plus nitrite (as nitrogen) and orthophosphorus (as phosphorus), because those nutrients constitute most of the total nutrient concentrations at below-normal and normal streamflow conditions at sites located downstream from the WWTFs on Indian Creek (Graham and others, 2014). During the 2014 and 2015 surveys, nitrate plus nitrite and orthophosphorus constituted most of the 
total nitrogen and total phosphorus concentrations, respectively. The median nitrate plus nitrite contribution to total nitrogen concentrations was 87 and 84 percent during the 2014 and 2015 sampling events, respectively; median orthophosphorus contributions to total phosphorus were 85 and 94 percent during 2014 and 2015, respectively (table 2). Nitrate plus nitrite and orthophosphorus had the lowest contribution to total concentrations, and particulate nutrients had the highest contributions, at sites located upstream from the WWTFs during the 2014 and 2015 sampling events (sites 119th, Switzer, and 30).

\section{Geographic Information Systems (GIS) Data Interpolation}

The spatially dense, sensor-measured nitrate data were entered into ArcGIS (ver. 10.3.1), and processed using the "Topo to Raster" tool in the "3-D Analyst Toolbox" to interpolate between data points and create maps that visually represent nitrate concentrations (Esri, 2016). Streamlines were buffered to 75 meters for data interpolation between points. Both the buffer data and data points used the projected coordinate system Universal Transverse Mercator (UTM) Zone 15 North with North American Datum (NAD) 1983.

\section{Cumulative Difference Analysis}

In order to quantitatively assess the longitudinal differences in spatially dense sensor-measured nitrate concentrations, the cumulative difference between data points was used.

Table 2. Percentage contribution of particulate nitrogen and nitrate plus nitrite to total nitrogen concentrations and particulate phosphorus and orthophosphorus to total phosphorus concentrations during the July 23, 2014, and August 26, 2015, surveys on Indian Creek, Johnson County, Kansas.

\begin{tabular}{lcccc}
\hline & $\begin{array}{c}\text { Percent } \\
\text { particulate } \\
\text { nitrogen }\end{array}$ & $\begin{array}{c}\text { Percent } \\
\text { nitrate plus } \\
\text { nitrite }\end{array}$ & $\begin{array}{c}\text { Percent } \\
\text { particulate } \\
\text { phospho- } \\
\text { rous }\end{array}$ & $\begin{array}{c}\text { Percent } \\
\text { orthophos- } \\
\text { phate }\end{array}$ \\
\hline \multicolumn{5}{c}{ July 23, 2014 } \\
\hline $\begin{array}{c}\text { Number of } \\
\text { samples }\end{array}$ & 37 & 37 & 33 & 32 \\
Minimum & 0.0 & 6.5 & 0.0 & 35.7 \\
Maximum & 20.8 & 90.8 & 25.0 & 95.0 \\
Median & 1.6 & 86.7 & 5.9 & 85.0 \\
\hline Number of & 55 & 56 & 50 & 50 \\
samples & & August 26, 2015 & & \\
Minimum & 0.0 & 5.9 & 0.0 & 50.6 \\
Maximum & 34.7 & 91.7 & 97.2 & 98.9 \\
Median & 1.8 & 84.4 & 3.2 & 93.6 \\
\hline
\end{tabular}

Cumulative difference was calculated as the sum of the differences between consecutive data points. Calculations were started immediately downstream from the Middle Basin effluent discharge, which was the point of maximum nitrate concentration, and calculations ended at the State Line site. Negative cumulative difference values indicate increases in nitrate concentration and positive values indicate decreases in concentration. To graphically represent changes in nitrate concentration along the upstream-downstream gradient, the distance of each data point downstream from the Middle Basin WWTF was calculated by measuring the distance between consecutive data points in GIS. This approach assumes that the distance between two points is defined by a straight line, which is not necessarily representative of the exact path traveled, leading to inaccuracies in estimated distance downstream from the WWTF.

\section{March 2012-June 2013 Sensor-Measured Nitrate Analyses}

Sensor-measured nitrate data collected from the six fixed sites on Indian Creek and Tomahawk Creek during March 2012-June 2013 (fig. 1, table 1) were analyzed to determine the broad spatial and temporal differences in concentration among sites. Nitrate concentrations were used to compute instantaneous loads (milligrams per second, $\mathrm{mg} / \mathrm{s}$ ) by multiplying concentration by discharge and by a conversion factor. Cyclical variability was quantified during below-normal and normal streamflow conditions by calculating the differences between the daily minimum and maximum concentrations.

\section{Nitrate Pulse Analysis}

Sensor-measured nitrate data at the College, Marty, and Mission Farms sites during March 2012-June 2013 indicated a cyclical pattern of increasing and decreasing nitrate concentrations. The cyclical pattern was verified as real, and not a sensor artifact, through the collection of discrete samples every hour over a 24-hour period at one site upstream from the Middle Basin WWTF (119th) and two downstream sites (College and Marty) (fig. 3A). During the 24-hour sampling, the cyclical pattern was most evident at the College site, located approximately $1.0 \mathrm{~km}$ downstream from the WWTF. Later data collected directly at the Middle Basin WWTF effluent discharge indicated that the cyclical patterns likely were caused by the WWTF, rather than in-stream processes (fig. 3B).

The cyclical nitrate pattern caused by the Middle Basin WWTF allowed maximum concentrations (hereinafter referred to as "pulses") to be tracked downstream from the WWTF between the College and Mission Farms sites. At the State Line site, the effect of the Middle Basin WWTF was masked by the Tomahawk Creek WWTF effluent discharge. Pulse maxima were selected for analysis because they provided the clearest signature to track pulse movement downstream (fig. 4A). The signatures of 146 pulses could be tracked 

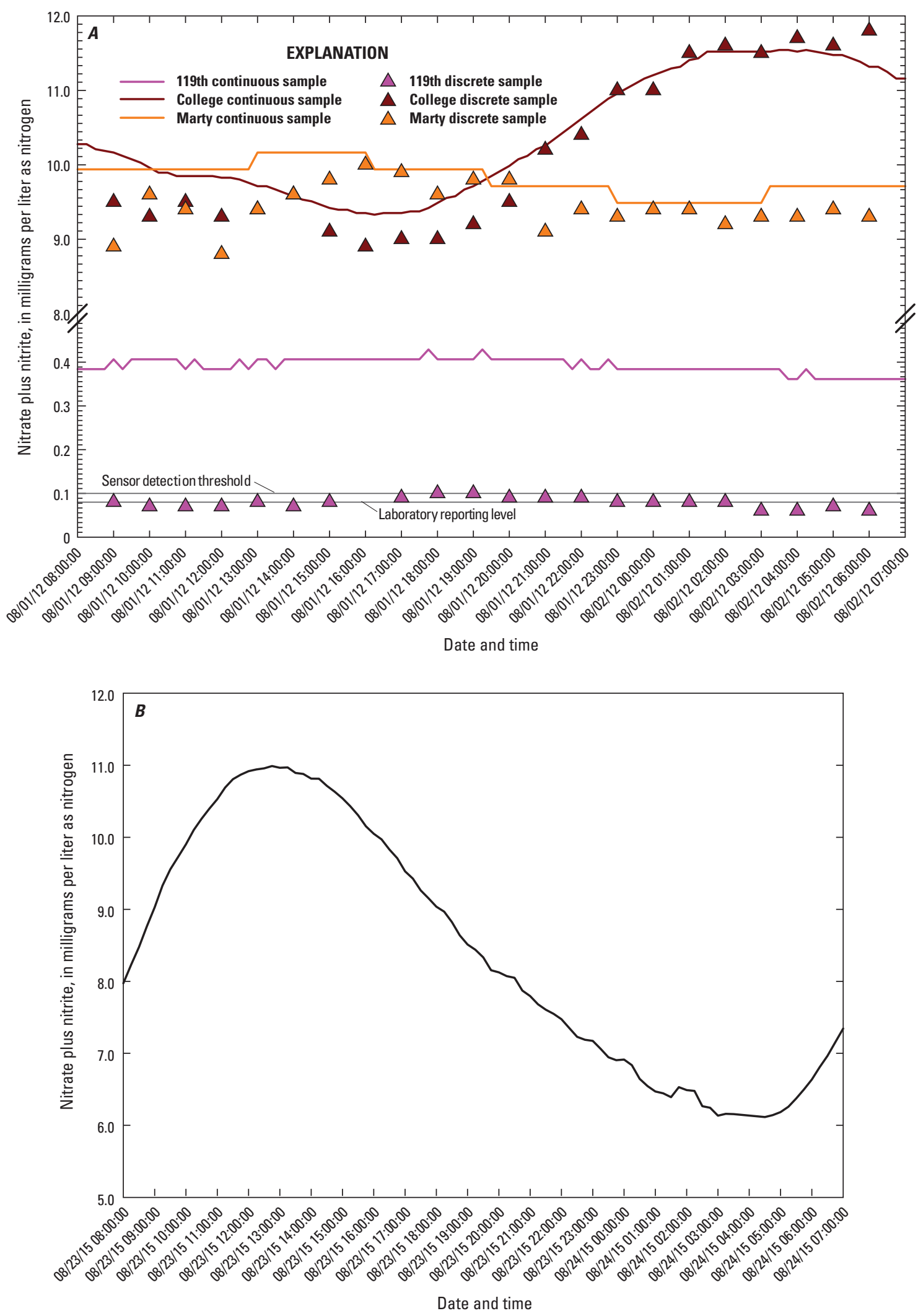

Figure 3. Cyclical patterns observed in Indian Creek nitrate plus nitrite concentrations (as nitrogen) at the $A, 119$ th, College, and Marty sampling sites, with discrete verification samples and $B$, directly in the Middle Basin effluent stream. 

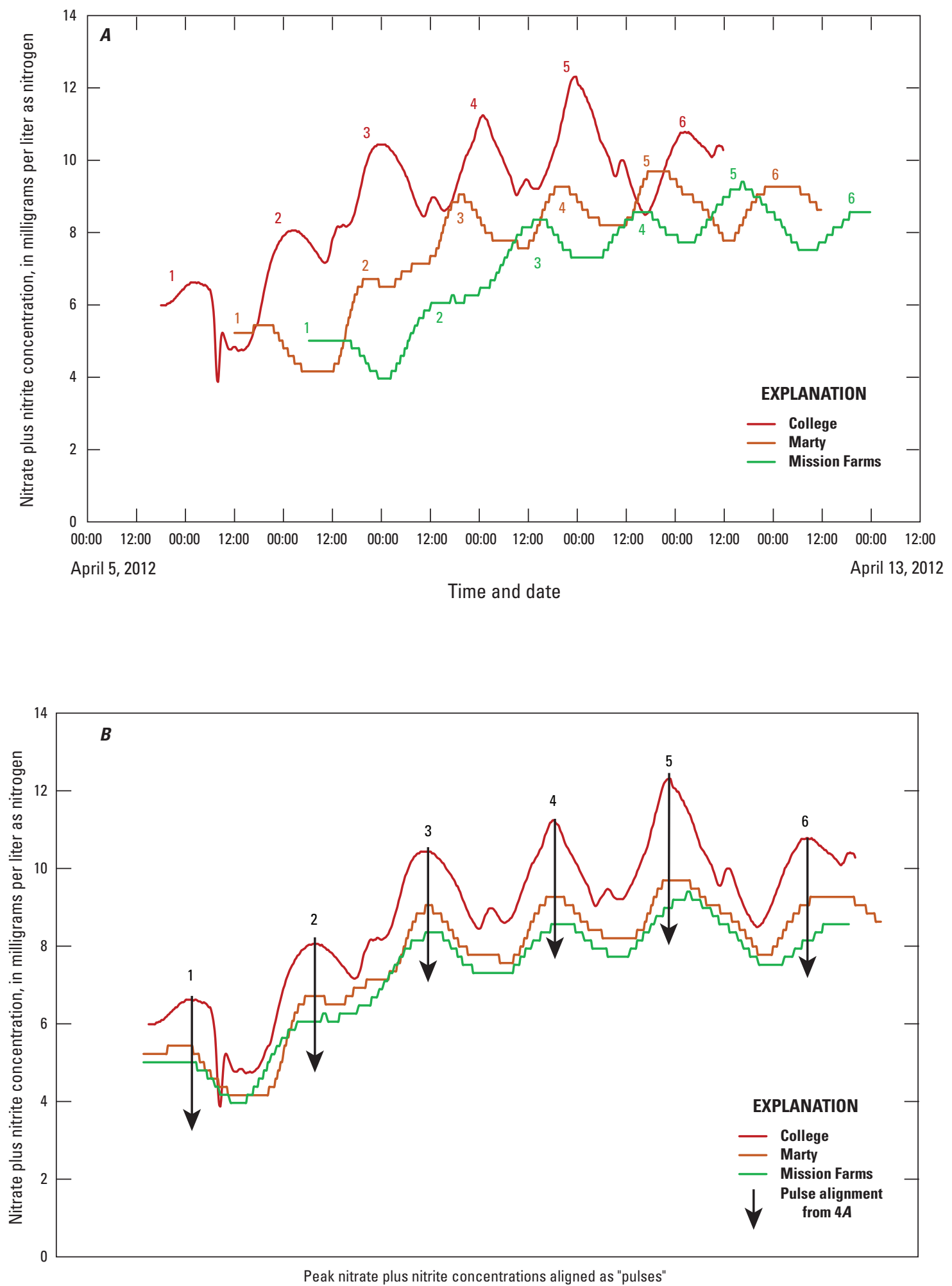

Figure 4. Example of pulse alignment used for data analysis. 
through all three downstream sites, and maxima from these pulses were aligned (fig. 4B). Aligning nitrate maxima generally allowed the same parcel of water to be tracked downstream and the change in nitrate concentration between sites was quantified on a pulse-by pulse basis.

Sensor-measured nitrate data from the College, Marty, and Mission Farms sites (2012-13) were analyzed for among-site and among-reach differences in pulse maximum nitrate concentrations. Data at each site were segregated into discrete ranges (bins) at specific concentrations. For amongsite comparisons, a bin size of $1 \mathrm{mg} / \mathrm{L}$ was used. For amongreach analysis, a bin size of $0.25 \mathrm{mg} / \mathrm{L}$ was used. Bin size was determined to allow a clear visualization of the overall pattern based on observed concentrations. Data were plotted based on the number of occurrences (frequency) of pulse maximum concentrations (for among-site comparisons) or pulse maximum concentration differences (for among-reach comparisons) within each bin. This allowed a visual representation of the distribution of peak nitrate concentrations at each site and the differences in peak nitrate concentrations between reaches.

\section{Spatially Dense Longitudinal Survey Results}

Four spatially dense longitudinal surveys were performed on Indian Creek during 2013-15, and included a combination of fixed-site sensors, floating-sensor arrays, and discrete sample collection. Surveys were performed over a range of below normal to slightly above-normal streamflow conditions, with wastewater effluent contributing from 38 to 100 percent of total streamflow. For simplicity, hereinafter all nitrate plus nitrite (as nitrogen) concentrations are referred to as "nitrate" and all orthophosphorus (as phosphorus) concentrations are referred to as "orthophosphorus."

\section{May 23, 2013}

A locally designed floating-sensor platform (fig. $2 A$ ) was tested from 10:45 to 18:00 on May 23, 2013. The primary purpose of the test was to assess if the platform could be used to conduct a Lagrangian (that is, follow a parcel of water downstream) water-quality survey in Indian Creek. The test was performed along an approximately $3.4-\mathrm{km}$ reach of Indian Creek between the College and Marty sites (fig. 1). On May 23, 2013, streamflow conditions were normal at the College $\left(16 \mathrm{ft}^{3} / \mathrm{s}\right)$ and Marty $\left(21 \mathrm{ft}^{3} / \mathrm{s}\right)$ sites, and wastewater effluent contributed about 100 percent and 80 percent to streamflow at each site, respectively. During normal conditions, differences in streamflow mostly are caused by differences in wastewater effluent contributions rather than additional sources of streamflow along the reach. Nitrate concentrations averaged 4.7 and $3.8 \mathrm{mg} / \mathrm{L}$ at the fixed College and Marty sites, respectively, on
May 23, 2013. Streamflow and nitrate conditions at both sites were similar in the 24 to 40 hours before the floating-sensor platform test on May 23, 2013.

The floating-sensor platform test indicated that greater stream depths were needed to effectively use the platform, because natural flow velocities were not adequate in shallow water to effectively move the free-floating platform downstream and follow the parcel of water. A different approach (kayaks) suitable for shallower depths and self-propulsion through pools was used in future surveys (fig. $2 B$ ). The test also indicated that true Lagrangian surveys of Indian Creek were impractical using this method, given the number of long, slow pools in the tested reach. Discrete nitrate samples for comparison with sensor-measured nitrate concentrations were not collected during this test since the primary objective was platform performance. However, sensor-measured nitrate concentrations during the test ( 4.2 to $4.9 \mathrm{mg} / \mathrm{L}$ ) were similar to sensor-measured nitrate concentrations at the fixed College (4.1 to $4.7 \mathrm{mg} / \mathrm{L}$ ) and Marty (3.5 to $4.2 \mathrm{mg} / \mathrm{L}$ ) sites during the same time period, and measurements reflect spatial patterns in nitrate concentration along the upstream-downstream gradient between the two sites (fig. 5).

Sensor-measured nitrate concentrations ranged from $4.2 \mathrm{mg} / \mathrm{L}$ to $4.9 \mathrm{mg} / \mathrm{L}$, but did not decrease linearly in the downstream direction (fig. 6). Nitrate concentrations changed by about $0.7 \mathrm{mg} / \mathrm{L}$ within the study reach, but the overall difference between the starting and ending locations was only about $0.3 \mathrm{mg} / \mathrm{L}$ (fig. $6 B$ ). Overall, nitrate concentrations were highest near the fixed College (sensor measured) site, located approximately $1.0 \mathrm{~km}$ downstream from the Middle Basin WWTF, and decreased by about $0.7 \mathrm{mg} / \mathrm{L}$ within $1.0 \mathrm{~km}$ downstream from the site (a rate of change of $0.7 \mathrm{mg} / \mathrm{L} / \mathrm{km}$ ). Nitrate concentrations varied little between 2.0 and $3.4 \mathrm{~km}$ downstream from the WWTF, and then increased by $0.3 \mathrm{mg} / \mathrm{L}$ over the last $1.0 \mathrm{~km}$ of the reach (fig. 6). Patterns in nitrate concentration along the upstream-downstream gradient reflect the cyclical pulse in nitrate from the Middle Basin WWTF (figs. 5 and 6). Nitrate concentrations at the fixed College (sensor measured) site decreased by about $1 \mathrm{mg} / \mathrm{L}$ between midnight and 07:00 on May 23, 2013 (fig. 5), and are likely reflected in the $0.7 \mathrm{mg} / \mathrm{L}$ decrease in nitrate concentrations within the first $1.0 \mathrm{~km}$ downstream from the fixed College (sensor measured) site (fig. 6B). Increased nitrate concentrations around $3.2 \mathrm{~km}$ downstream from the Middle Basin WWTF likely reflect the peak in nitrate concentrations that occurred at the fixed College (sensor measured) site shortly after midnight on May 23, 2013 (figs. 5 and 6).

\section{July 23, 2014}

The July 23, 2014, survey was performed from 07:00 to 21:00 along the 13.2-km reach of Indian Creek, from the Switzer to State Line sites (fig. 1). Fixed-site nitrate and other water-quality parameters were operated at the Switzer, Middle Basin WWTF, and Marty sites for 48 hours, from the 


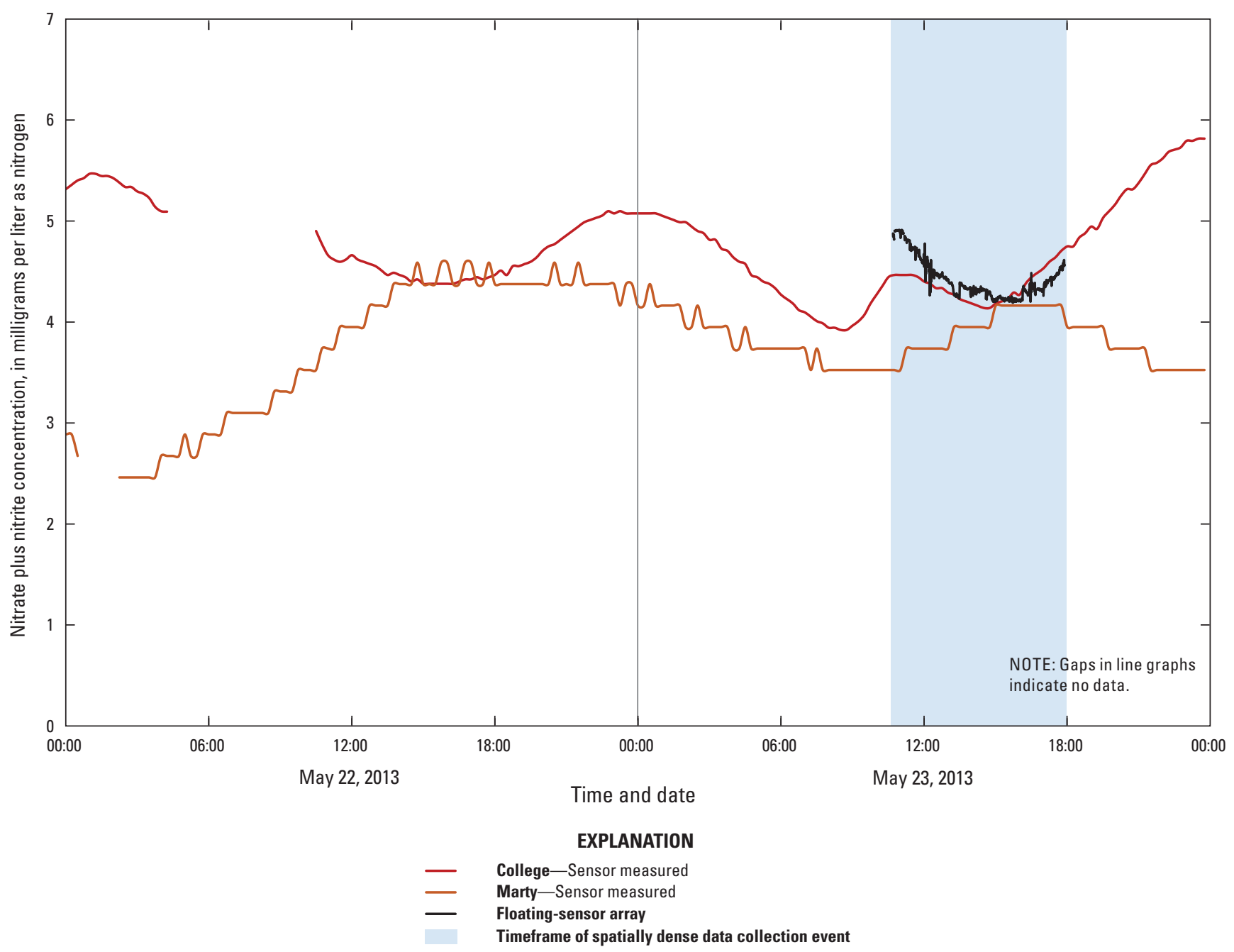

Figure 5. Nitrate plus nitrite concentrations (as nitrogen) at the fixed College and Marty sites and along the reach between the two fixed sites during May 22 through May 23, 2013, Johnson County, Kansas.

afternoon of July 22 through the afternoon of July 25 . The nitrate sensor at the Switzer site stopped recording data after 4 hours of operation and data for this site are not included in the report. Discrete water-quality samples for nutrient analysis were collected approximately every $0.5 \mathrm{~km}$ from the Switzer to State Line sites, from the Middle Basin and Tomahawk Creek WWTF effluent, and from five tributary streams (Tributaries 1-4 and Tomahawk Creek; fig. 1). Streamflow conditions along the study reach were evaluated using data from the long-term gaging stations (operated for the Graham and others, 2014 study) located at Marty and State Line sites. In addition, streamflow was measured at the five tributary stream sites (fig. 1).

Streamflow conditions on July 23, 2014, were dominated by wastewater effluent, with very little flow contribution from tributary streams. Streamflow conditions were below normal at the Marty $\left(10 \mathrm{ft}^{3} / \mathrm{s}\right)$ and State Line $\left(19 \mathrm{ft}^{3} / \mathrm{s}\right)$ sites on July 23,2014 , and wastewater effluent contributed about 100 percent to streamflow at both sites. Streamflow conditions and wastewater effluent contributions at the Marty and State Line sites during the week before the survey were similar to those observed on July 23, 2014. The greatest tributary streamflows were measured at the Tributary 3 site $\left(0.49 \mathrm{ft}^{3} / \mathrm{s}\right)$ and Tomahawk Creek site $\left(0.99 \mathrm{ft}^{3} / \mathrm{s}\right)$; all other tributaries had streamflows less than $0.2 \mathrm{ft}^{3} / \mathrm{s}$.

The WWTFs were the main source of nutrients to Indian Creek on July 23, 2014. Nitrate and orthophosphorus concentrations in the Middle Basin effluent were 11.7 and $2.6 \mathrm{mg} / \mathrm{L}$, respectively. In the Tomahawk Creek WWTF effluent, nitrate and orthophosphorus concentrations were 7.9 and $1.5 \mathrm{mg} / \mathrm{L}$, respectively. Nitrate concentrations in all of the tributary streams except for Tributary 2 were less than $0.2 \mathrm{mg} / \mathrm{L}$. Similarly, orthophosphorus concentrations in all tributary streams except Tributary 2 were at or below the laboratory reporting level of $0.05 \mathrm{mg} / \mathrm{L}$ (Michele Anderson, Johnson County Water Quality Laboratory, written commun., 2014 and 2015). Tributary 2 had nitrate and orthophosphorus concentrations of 10.4 and $1.4 \mathrm{mg} / \mathrm{L}$, respectively. The Tributary 2 sample location likely was directly affected by backwater from Indian Creek, rather than reflecting another nutrient source. 

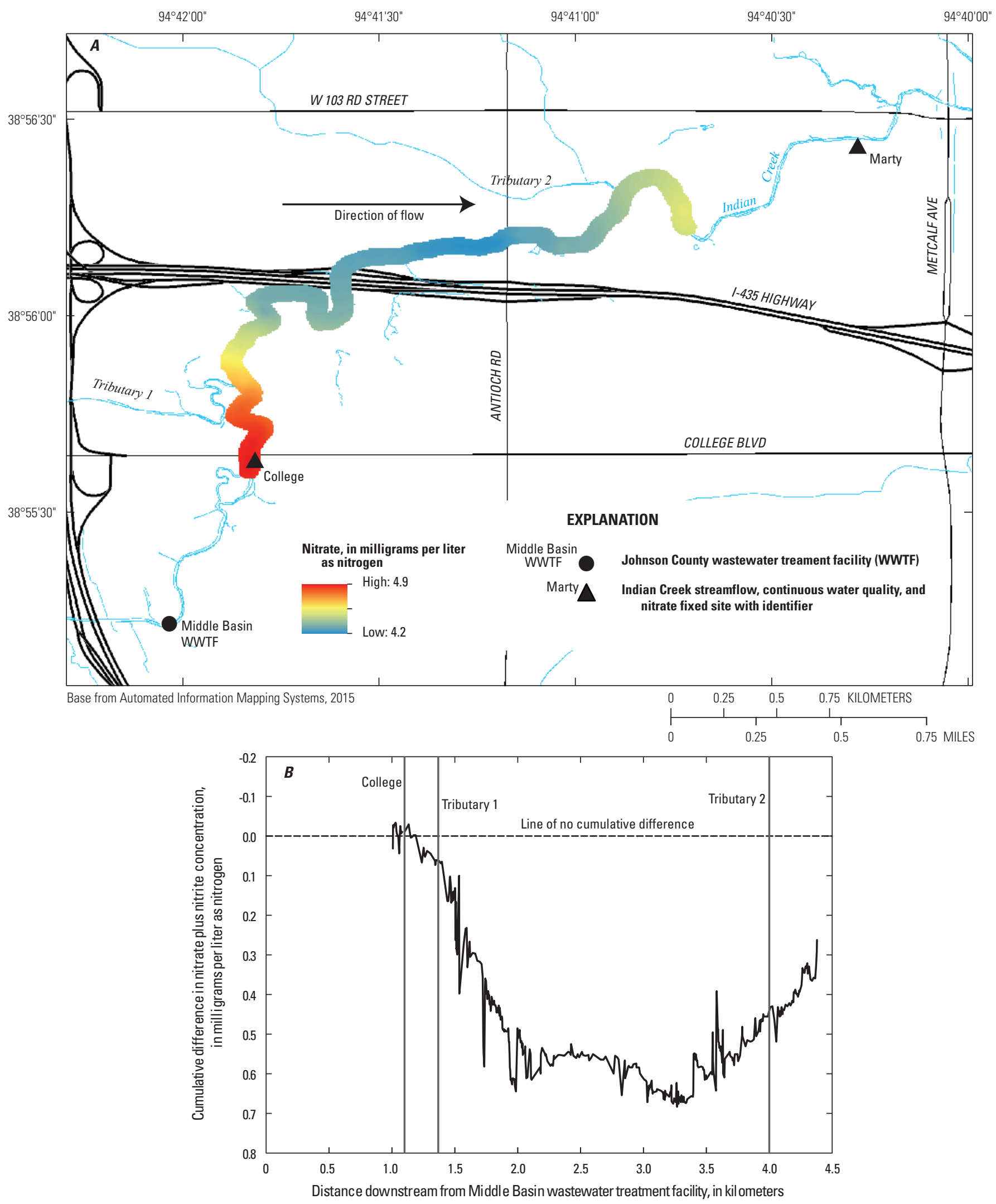

EXPLANATION

Figure 6. Collected or calculated nitrate plus nitrite (as nitrogen) data along the study reach on May 23, 2013, Johnson County, Kansas. $A$, sensor-measured nitrate plus nitrite concentrations (as nitrogen) and $B$, cumulative difference in nitrate plus nitrite concentrations (as nitrogen). 
The fixed-site nitrate sensor data were not corrected to laboratory samples because only one discrete sample was collected at each site. The available data indicate that sensormeasured nitrate concentrations were similar (within 4 percent at Middle Basin WWTF and 15 percent at Marty; fig. 7) to the laboratory-measured concentrations and likely reflect temporal and spatial patterns, but not necessarily actual concentrations. The fixed-site nitrate (sensor measured) at the Middle Basin WWTF and Marty sites indicated a clear cyclical pattern in nitrate concentrations. Nitrate concentrations at the Middle Basin WWTF decreased from a high of $14.9 \mathrm{mg} / \mathrm{L}$ at $17: 15$ on July 22, 2014, to $11.1 \mathrm{mg} / \mathrm{L}$ at $13: 30$ on July 23, 2014. A second, smaller peak in nitrate concentration $(12.5 \mathrm{mg} / \mathrm{L})$ occurred at $22: 15$ on July 23,2014 , followed by another minimum (10.4 mg/L) at 12:15 on July 24, 2014 (fig. 7). At the Marty site, nitrate concentrations ranged from a minimum of $9.7 \mathrm{mg} / \mathrm{L}$ at $17: 15$ on July 22,2014 , to a maximum of $11.2 \mathrm{mg} / \mathrm{L}$ at $19: 45$ on July 23, 2015. The peak nitrate concentrations observed at the Marty site on July 23, 2014, likely reflect the peak that occurred at the Middle Basin WWTF on July 22, 2014.

The spatial nitrate sensor data were corrected to laboratory samples following Graham and others (2014) using the discrete samples collected approximately every $0.5 \mathrm{~km}$ along the study reach. The regression models to correct nitrate sensor data are in appendixes 1 and 2. The nitrate sensor malfunctioned approximately $3.2 \mathrm{~km}$ downstream from the Middle Basin WWTF and was replaced with another sensor approximately $5.3 \mathrm{~km}$ downstream, resulting in an approximately $2.1 \mathrm{~km}$ data gap. The second sensor malfunctioned approximately $8.5 \mathrm{~km}$ downstream and the issue was resolved approximately $9.3 \mathrm{~km}$ downstream, resulting in an approximately $0.8 \mathrm{~km}$ data gap. Discrete-sample data fill in those gaps and the overall pattern along the reach is evident (fig. 8A). Sensor-measured nitrate concentrations ranged from

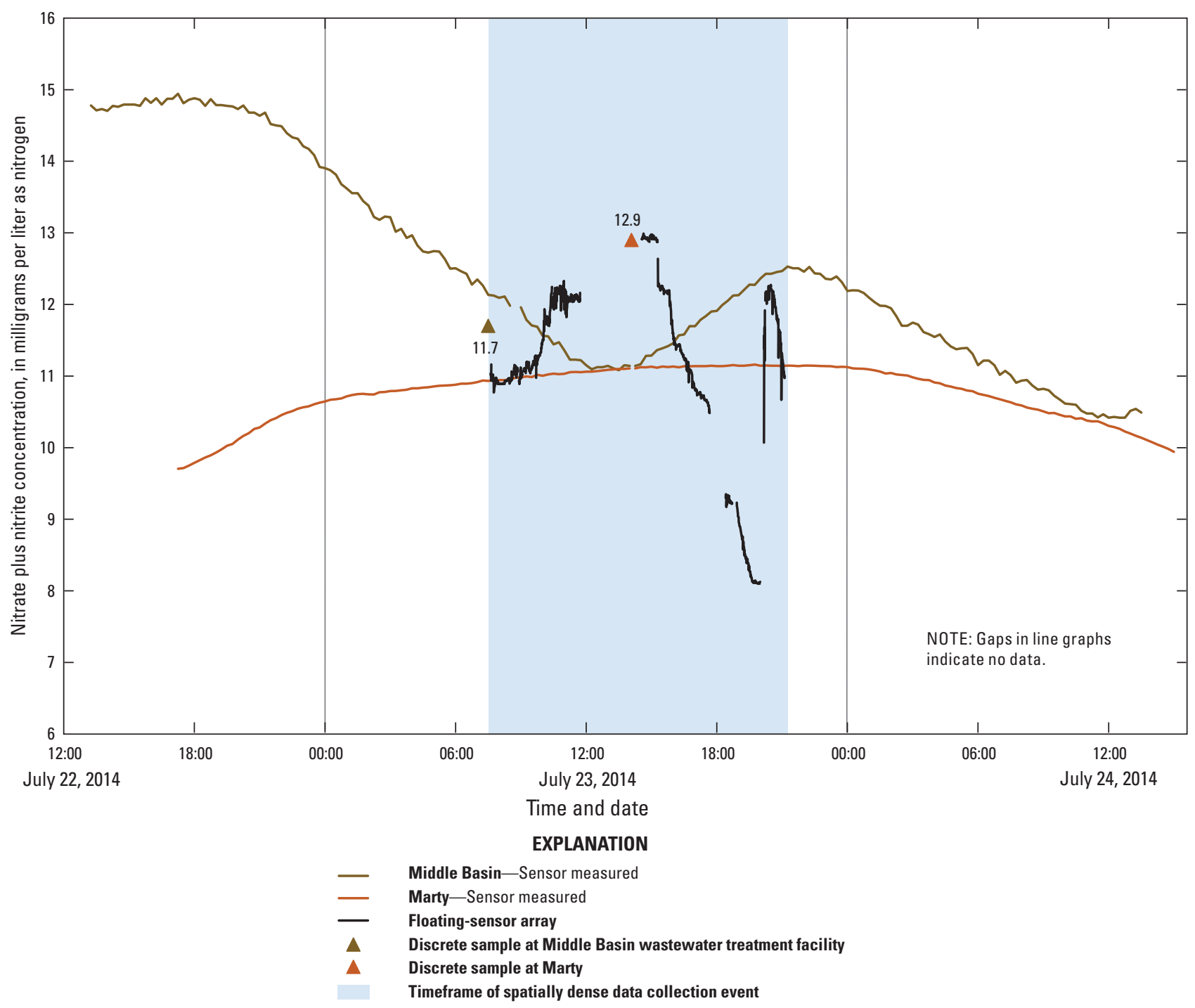

Figure 7. Nitrate plus nitrite concentrations (as nitrogen) at the fixed Middle Basin wastewater treatment facility and Marty sites and along the entire study reach on July 22-24, 2014, Johnson County, Kansas. 

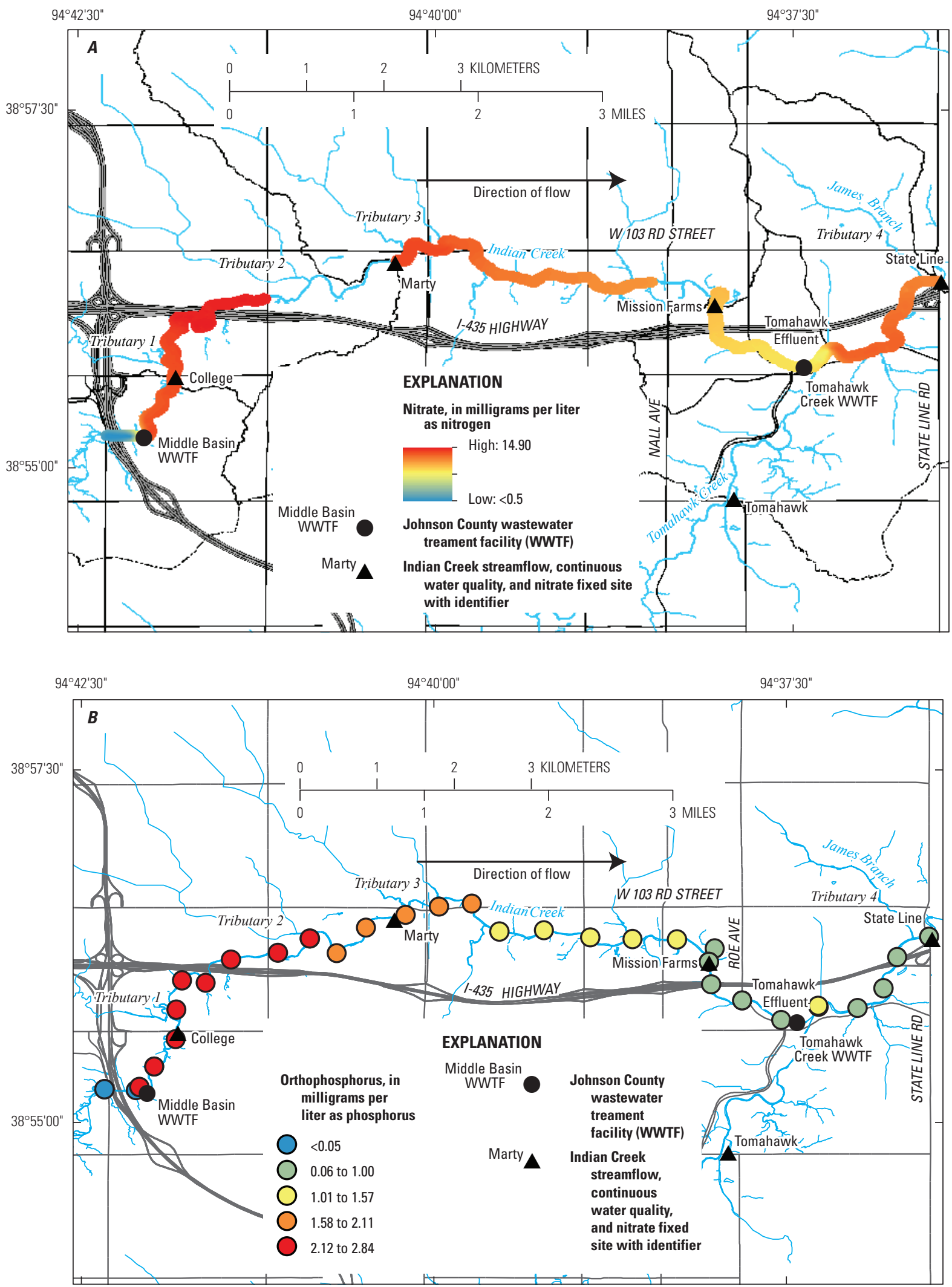

Base from Automated Information Mapping Systems, 2015

Figure 8. Nitrate plus nitrite (as nitrogen)and orthophosphorus (as phosphorus) data along the study reach on July 23, 2014, Johnson County, Kansas. A, sensor-measured nitrate plus nitrite concentrations (as nitrogen). $B$, discrete sample orthophosphorus concentrations (as phosphorus), $C$, cumulative difference in nitrate plus nitrite concentration (as nitrogen), and $D$, cumulative difference in orthophosphorus concentration (as phosphorus). 


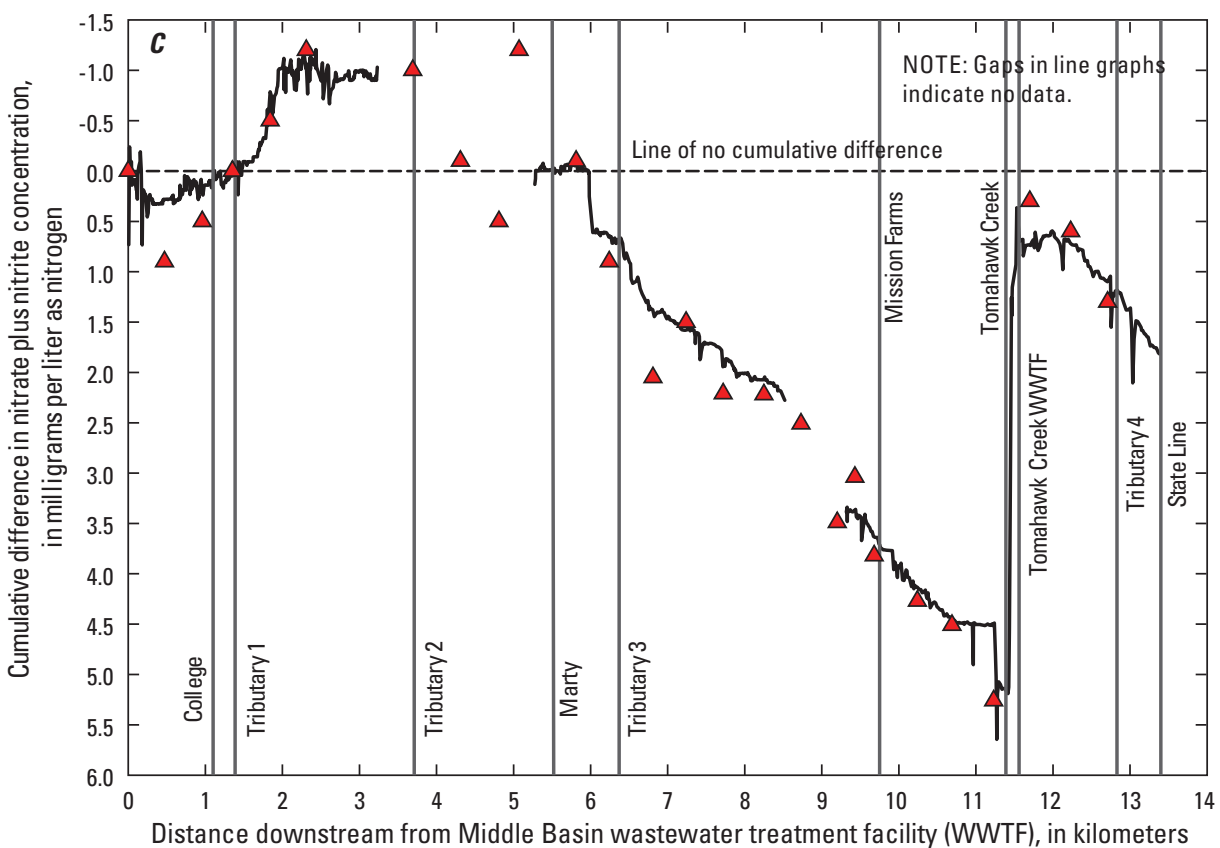

EXPLANATION

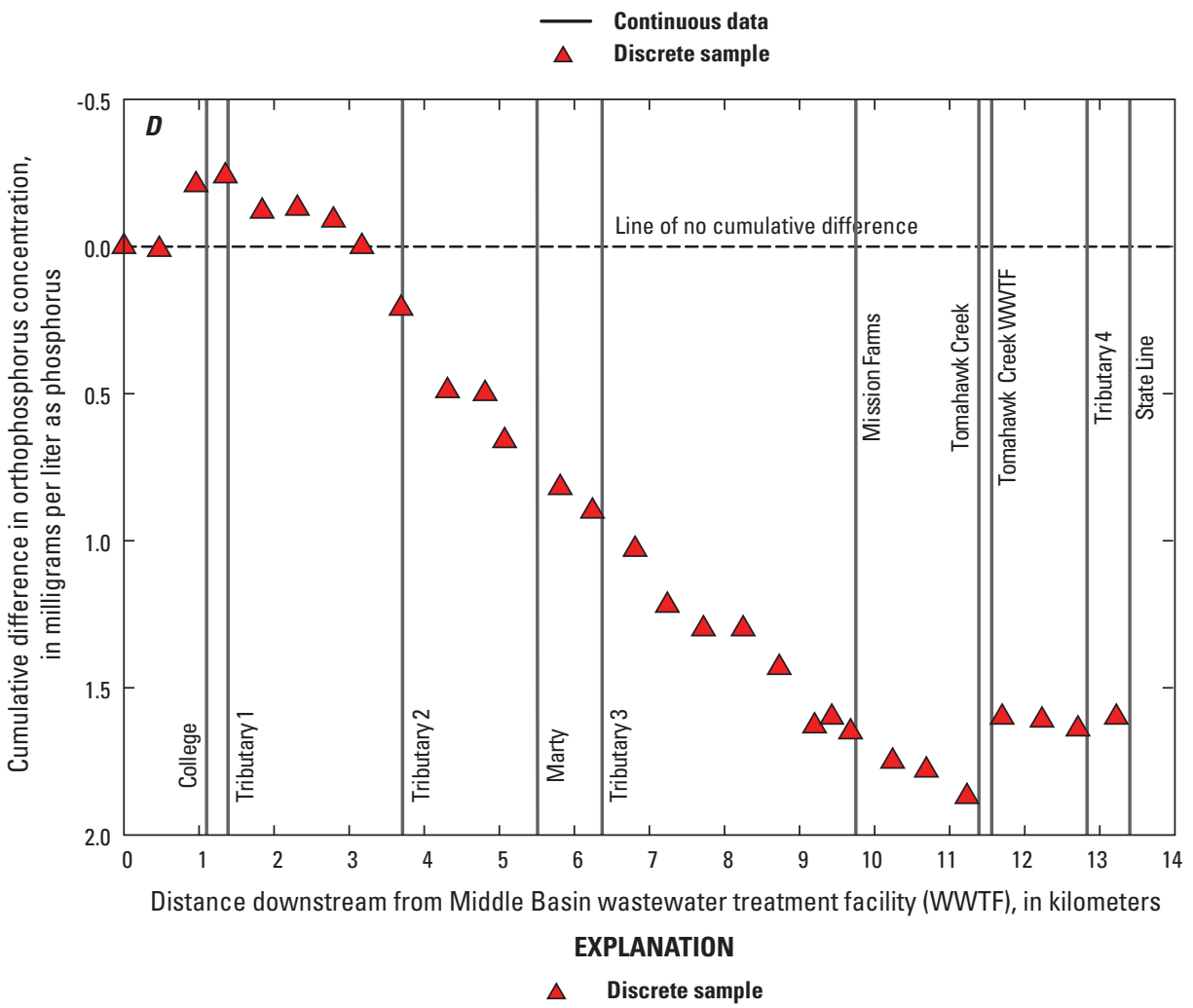

Figure 8. Nitrate plus nitrite (as nitrogen) and orthophosphorus (as phosphorus) data along the study reach on July 23, 2014, Johnson County, Kansas. $A$, sensor-measured nitrate plus nitrite concentrations (as nitrogen). $B$, discrete sample orthophosphorus concentrations (as phosphorus), $C$, cumulative difference in nitrate plus nitrite concentration (as nitrogen), and $D$, cumulative difference in orthophosphorus concentration (as phosphorus).-Continued 
below the minimum detection threshold $(0.1 \mathrm{mg} / \mathrm{L})$ upstream from the Middle Basin WWTF to a maximum of $12.8 \mathrm{mg} / \mathrm{L}$ approximately $2.5 \mathrm{~km}$ downstream from the Middle Basin WWTF (fig. 8A, C). Nitrate concentrations decreased by about $0.5 \mathrm{mg} / \mathrm{L}$ between the Middle Basin WWTF and approximately $0.5 \mathrm{~km}$ downstream (a rate of change of about $1 \mathrm{mg} / \mathrm{L} / \mathrm{km}$ ), then increased to the observed maximum of $12.8 \mathrm{mg} / \mathrm{L}$ over the next $2.0 \mathrm{~km}$ (fig. $8 \mathrm{C}$ ). This increase likely reflects the most recent (day before) peak in nitrate concentrations from the Middle Basin WWTF. Nitrate concentrations decreased steadily at a rate of change of about $0.3 \mathrm{mg} / \mathrm{L} / \mathrm{km}$ from approximately $6.0 \mathrm{~km}$ downstream from the Middle Basin WWTF to the confluence with Tomahawk Creek, where concentrations dropped rapidly (about $20 \mathrm{mg} / \mathrm{L} / \mathrm{km}$ ) to a downstream minimum of $6.0 \mathrm{mg} / \mathrm{L}$. Nitrate concentrations rapidly increased by $5.3 \mathrm{mg} / \mathrm{L}$ (from 6.0 to $11.3 \mathrm{mg} / \mathrm{L}$ ) immediately downstream from the Tomahawk Creek WWTF (fig. 8C). Downstream from the Tomahawk Creek WWTF, nitrate concentrations decreased at a slower rate of change (about $0.79 \mathrm{mg} / \mathrm{L} / \mathrm{km}$ ) than observed immediately downstream from the Middle Basin WWTF, but at a faster rate than observed over most of the study reach, to a concentration of $9.8 \mathrm{mg} / \mathrm{L}$ at State Line.

Changes in discrete orthophosphorus concentrations along the study reach were not as pronounced as nitrate concentrations (fig. 8). Orthophosphorus concentrations ranged from less than the laboratory reporting level $(0.05 \mathrm{mg} / \mathrm{L})$ upstream from the Middle Basin WWTF to a maximum of $2.8 \mathrm{mg} / \mathrm{L}$ approximately $1 \mathrm{~km}$ downstream from the Middle Basin WWTF (fig. 8B). Orthophosphorus concentrations decreased steadily at a rate of change of about $0.2 \mathrm{mg} / \mathrm{L} / \mathrm{km}$ from approximately $3.0 \mathrm{~km}$ downstream from the Middle Basin WWTF to the confluence with Tomahawk Creek, where the downstream minimum of $0.7 \mathrm{mg} / \mathrm{L}$ was observed (fig. $8 B$, $D)$. Unlike nitrate concentrations, orthophosphorus concentrations did not decrease rapidly at the confluence with Tomahawk Creek (fig. 8). Orthophosphorus concentration increased by $0.3 \mathrm{mg} / \mathrm{L}$ (from 0.7 to $1.0 \mathrm{mg} / \mathrm{L}$ ) immediately downstream from the Tomahawk Creek WWTF. Orthophosphorus concentrations did not change between the Tomahawk Creek WWTF and State Line (fig. $8 B, D$ ).

\section{July 30, 2015}

The July 30, 2015, survey was performed from 07:00 to $15: 00$ along the $13.2-\mathrm{km}$ reach of Indian Creek, from the Switzer to State Line sites (fig. 1). Fixed-site nitrate and other water-quality sensors were not operated and discrete waterquality samples were not collected as part of this survey; therefore, laboratory sample data were not available to correct nitrate sensor data. Therefore, sensor data likely reflect spatial patterns in nitrate, but not necessarily actual nitrate concentrations. Streamflow conditions along the study reach were evaluated using data from the long-term gaging stations (operated for the Graham and others, 2014 study) located at Marty and
State Line. On July 30, 2015, streamflow conditions were normal at the Marty $\left(24 \mathrm{ft}^{3} / \mathrm{s}\right)$ site and slightly above-normal at the State Line $\left(69 \mathrm{ft}^{3} / \mathrm{s}\right)$ site, and wastewater effluent contributed about 68 percent and 38 percent to streamflow at each site, respectively. A small runoff event occurred within 24 hours of the July 30, 2015, survey, but streamflows at the Marty and State Line sites had returned to conditions similar to those before the event before the survey was performed, and nitrate concentrations were likely approaching background, pre-event conditions.

Sensor-measured nitrate concentrations ranged from a minimum of $0.7 \mathrm{mg} / \mathrm{L}$ upstream from the Middle Basin WWTF to a maximum of $6.4 \mathrm{mg} / \mathrm{L}$ approximately $0.1 \mathrm{~km}$ downstream from the Middle Basin WWTF (fig. 9A). Nitrate concentrations decreased by about $1.5 \mathrm{mg} / \mathrm{L}$ between the Middle Basin WWTF and approximately $1.5 \mathrm{~km}$ downstream (a rate of change of about $1 \mathrm{mg} / \mathrm{L} / \mathrm{km}$ ), then increased by about $1.0 \mathrm{mg} / \mathrm{L}$ to a smaller maximum of $5.2 \mathrm{mg} / \mathrm{L}$ over the next $1.5 \mathrm{~km}$ (fig. 9B). This increase likely reflects the most recent peak (day before) in nitrate concentrations from the Middle Basin WWTF. Nitrate concentrations decreased steadily at a rate of change of about $0.4 \mathrm{mg} / \mathrm{L} / \mathrm{km}$ from approximately $3.0 \mathrm{~km}$ downstream from the Middle Basin WWTF to the confluence with Tomahawk Creek, where concentrations dropped more rapidly (about $1.5 \mathrm{mg} / \mathrm{L} / \mathrm{km}$ ) to a downstream minimum of $1.5 \mathrm{mg} / \mathrm{L}$. Nitrate concentrations rapidly increased by $2.9 \mathrm{mg} / \mathrm{L}$ (from 1.5 to $4.4 \mathrm{mg} / \mathrm{L}$ ) immediately downstream from the Tomahawk Creek WWTF (fig. 9B). Downstream from the Tomahawk Creek WWTF, nitrate concentrations decreased at a slower rate of change than observed upstream (about $0.2 \mathrm{mg} / \mathrm{L} / \mathrm{km}$ ) to a concentration of $4.1 \mathrm{mg} / \mathrm{L}$ at the State Line site.

\section{August 26, 2015}

Two surveys were performed on August 26, 2015, both along the 13.2-km reach of Indian Creek, from the Switzer to State Line sites (fig. 1). The first survey was performed from 06:30 to $17: 00$, and the second survey was performed from 12:00 to 19:00. The start times of the surveys were offset by 6 hours to better characterize differences caused by the cyclical fluctuations in nitrate concentration at the Middle Basin WWTF. Discrete water-quality samples for nutrient analysis were collected every $0.5 \mathrm{~km}$ during the first survey, every $1.0 \mathrm{~km}$ during the second survey, from the Middle Basin and Tomahawk Creek WWTF effluent, and from five tributary streams (Tributaries 1-4 and Tomahawk Creek; fig. 1). Fixed-site sensors were operated at the Middle Basin WWTF from August 21 through August 27 and at the Marty site from August 23 through August 27. Streamflow conditions along the study reach were evaluated using data from the long-term gaging stations (operated for the Graham and others, 2014 study) located at Marty and State Line sites. In addition, streamflow was measured on August 26, 2015, at the five tributary streams (Tributaries 1-4 and Tomahawk Creek; fig. 1). 

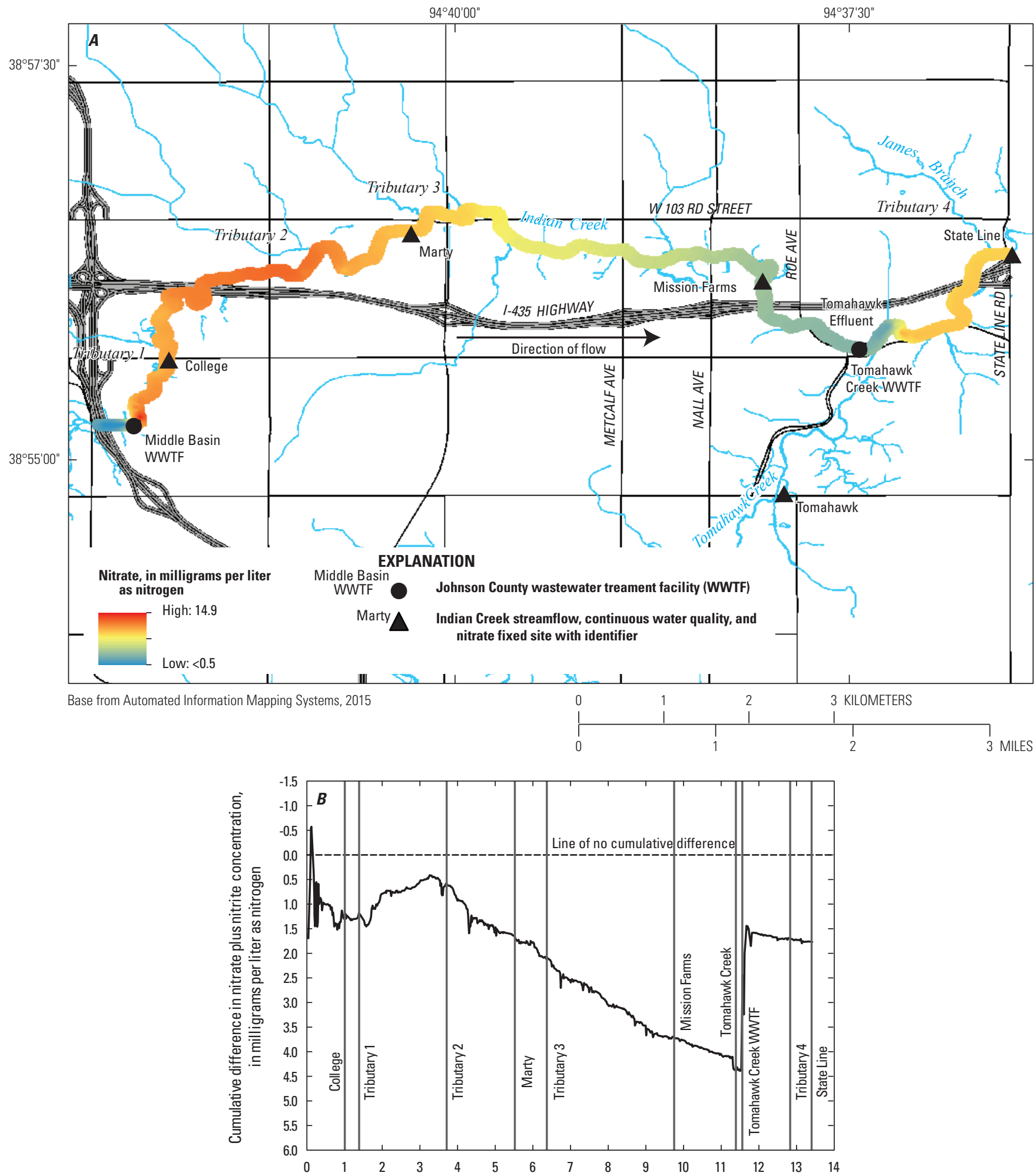

Distance downstream from Middle Basin wastewater treatment facility (WWTF), in kilometers

EXPLANATION

Figure 9. Nitrate plus nitrite (as nitrogen) data along the study reach on July 30, 2015, Johnson County, Kansas. A, sensormeasured nitrate plus nitrite concentrations (as nitrogen) and $B$, cumulative difference in nitrate plus nitrite concentration (as nitrogen). 
Streamflow conditions on August 26, 2015, were dominated by wastewater effluent. Streamflow conditions were normal at the Marty $\left(14 \mathrm{ft}^{3} / \mathrm{s}\right)$ and State Line $\left(30 \mathrm{ft}^{3} / \mathrm{s}\right)$ sites on August 26, 2015, and wastewater effluent contributed about 95 percent and 71 percent, respectively, to streamflow at these sites. Streamflow conditions and wastewater effluent contributions at the Marty and State Line sites during the week before the survey were similar to those observed on August 26, 2015. The highest tributary streamflows were measured at Tributary $1\left(0.39 \mathrm{ft}^{3} / \mathrm{s}\right)$ and Tomahawk Creek $\left(3.0 \mathrm{ft}^{3} / \mathrm{s}\right)$; all other tributaries had streamflows of $0.05 \mathrm{ft}^{3} / \mathrm{s}$ or less.

The WWTFs were the main source of nutrients to Indian Creek on August 26, 2015. Nitrate and orthophosphorus concentrations in the Middle Basin effluent were 11.0 and $2.1 \mathrm{mg} / \mathrm{L}$, respectively at $07: 00$ and 11.4 and $2.3 \mathrm{mg} / \mathrm{L}$, respectively at 12:10. In the Tomahawk Creek effluent, nitrate and orthophosphorus concentrations were 17.5 and $1.3 \mathrm{mg} / \mathrm{L}$, respectively. Nitrate concentrations in all of the tributary streams except for Tributary 2 were less than $0.5 \mathrm{mg} / \mathrm{L}$. Similarly, orthophosphorus concentrations in all tributary streams except Tributary 2 were at or below the laboratory reporting level of $0.05 \mathrm{mg} / \mathrm{L}$. Tributary 2 had nitrate and orthophosphorus concentrations of 2.0 and $0.4 \mathrm{mg} / \mathrm{L}$, respectively. As noted in 2014, the Tributary 2 sample location likely was directly affected by backwater from Indian Creek, rather than reflecting another nutrient source.

The fixed-site nitrate sensor data were not corrected to laboratory samples because only one or two discrete samples were collected at each site. The available data indicated that sensor-measured nitrate concentrations were similar (within 12 percent at Middle Basin WWTF and 4 percent at the Marty site; fig. 10) to laboratory-measured concentrations and likely reflect temporal and spatial patterns in nitrate, but not necessarily actual concentrations. The fixed-site nitrate (sensor measured) at the Middle Basin WWTF and Marty sites indicated clear cyclical patterns in nitrate concentrations. Nitrate concentrations at the Middle Basin WWTF ranged from $6.1 \mathrm{mg} / \mathrm{L}$ to $14.7 \mathrm{mg} / \mathrm{L}$, and varied by 4.0 to $6.0 \mathrm{mg} / \mathrm{L}$ during each cycle, with an approximate 12-hour difference between observed minima and maxima. The timing of minima and maxima were not consistent, but typically, minima occurred late at night or early in the morning and maxima occurred in the afternoon or early evening (fig. 10). Nitrate concentrations at the Marty site ranged from 4.9 to $10.8 \mathrm{mg} / \mathrm{L}$, and varied by 2.0 to $4.0 \mathrm{mg} / \mathrm{L}$ during each cycle, with an approximate 12-hour difference between observed minima and maxima. As observed at Middle Basin WWTF, the timing of minima and maxima were not consistent; unlike Middle Basin WWTF, minima at Marty occurred mid to late morning and maxima occurred in mid to late evening. The peak nitrate concentrations observed at the Marty site likely reflect the peak that occurred at Middle Basin the day before. For example, the Middle Basin WWTF nitrate peak of $12.0 \mathrm{mg} / \mathrm{L}$ at 17:45 on August 24 is reflected in the Marty nitrate peak of $8.6 \mathrm{mg} / \mathrm{L}$ after midnight on August 26 (fig. 10). This pattern indicates that peak nitrate concentration declined by $3.4 \mathrm{mg} / \mathrm{L}$ between the two sites, a rate of decrease of about $0.62 \mathrm{mg} / \mathrm{L} / \mathrm{km}$ between the Middle Basin WWTF and the Marty site. Comparing the peak nitrate concentration at Middle Basin on August $25(14.7 \mathrm{mg} / \mathrm{L}$ ) with the peak nitrate concentration at Marty on August 26 $(10.8 \mathrm{mg} / \mathrm{L})$ indicates a similar difference $(3.9 \mathrm{mg} / \mathrm{L})$ and rate of decrease $(0.8 \mathrm{mg} / \mathrm{L} / \mathrm{km})$ between the two sites.

The spatial nitrate sensor data were corrected to laboratory samples as described in Graham and others (2014) using the discrete samples collected approximately every $0.5 \mathrm{~km}$ or $1.0 \mathrm{~km}$ along the study reach. Each survey performed on August 26, 2015 corrected nitrate sensor data using the discrete samples collected as part of that survey; data from the two surveys were not combined. Because nitrate data were corrected using regression models specific to each sensor, the minimum detection thresholds are different between the two surveys (first survey, $0.5 \mathrm{mg} / \mathrm{L}$; second survey $0.1 \mathrm{mg} / \mathrm{L}$ ). The regression models to correct nitrate sensor data are in appendixes 3 and 4 .

Sensor-measured nitrate concentrations from the first August 26, 2015, survey ranged from less than $0.5 \mathrm{mg} / \mathrm{L}$ upstream from the Middle Basin WWTF to a maximum of $11.6 \mathrm{mg} / \mathrm{L}$ (fig. 11A). Nitrate concentrations increased steadily from $10.7 \mathrm{mg} / \mathrm{L}$ immediately downstream from the Middle Basin WWTF to the observed maximum of $11.6 \mathrm{mg} / \mathrm{L}$ approximately $1.3 \mathrm{~km}$ downstream from the Middle Basin WWTF (a rate of change of about $0.7 \mathrm{mg} / \mathrm{L} / \mathrm{km}$; fig. 11A, C). Nitrate concentrations rapidly decreased by about $1.5 \mathrm{mg} / \mathrm{L}$ at the confluence with Tributary 1 , and then increased to a second maximum of $11.3 \mathrm{mg} / \mathrm{L}$ approximately $2.8 \mathrm{~km}$ downstream from the Middle Basin WWTF. Nitrate concentrations decreased steadily from approximately $2.8 \mathrm{~km}$ downstream from the Middle Basin WWTF to the confluence with Tomahawk Creek. Concentrations decreased more rapidly from approximately $8.6 \mathrm{~km}$ downstream to the confluence with Tomahawk Creek (from 6.9 to $3.5 \mathrm{mg} / \mathrm{L}$, a rate of change of about $1.4 \mathrm{mg} / \mathrm{L} / \mathrm{km})$, than between $2.8 \mathrm{~km}$ and $8.6 \mathrm{~km}$ downstream (from 11.3 to $6.9 \mathrm{mg} / \mathrm{L}$, a rate of change of about $0.8 \mathrm{mg} / \mathrm{L} / \mathrm{km}$ ) (fig. $11 \mathrm{C}$ ). At the confluence with Tomahawk Creek, nitrate concentrations dropped rapidly (about $3.0 \mathrm{mg} / \mathrm{L} / \mathrm{km}$ ) to a downstream minimum of $2.0 \mathrm{mg} / \mathrm{L}$. Nitrate concentrations rapidly increased by $6.6 \mathrm{mg} / \mathrm{L}$ (from $2.0 \mathrm{mg} / \mathrm{L}$ to $8.6 \mathrm{mg} / \mathrm{L}$ ) immediately downstream from the Tomahawk Creek WWTF (fig. 11A, C). Downstream from the Tomahawk Creek WWTF, nitrate concentrations decreased at a slower rate of change than observed elsewhere along the study reach (about $0.4 \mathrm{mg} / \mathrm{L} / \mathrm{km}$ ) to a concentration of $7.9 \mathrm{mg} / \mathrm{L}$ at the State Line site.

General patterns in nitrate concentrations along the upstream-downstream gradient were similar between the first and second surveys on August 26, 2015; however, the distance downstream at which maxima and changes in concentration were observed differed between the two surveys because effluent from the Middle Basin WWTF traveled farther downstream (fig. 11C). Sensor-measured nitrate concentrations from the second survey on August 26, 2015, ranged from below the 


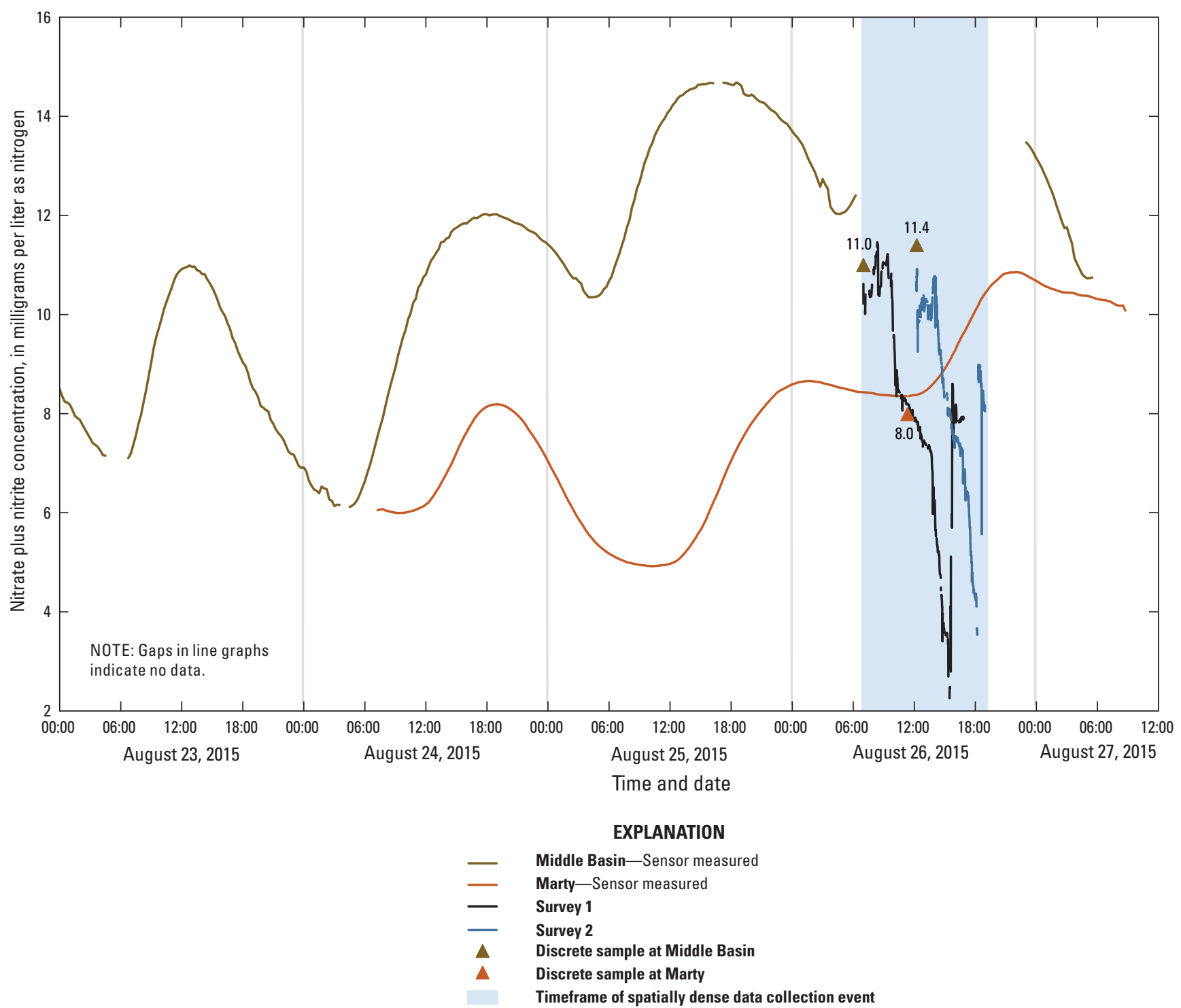

Figure 10. Nitrate plus nitrite concentrations (as nitrogen) at the fixed Middle Basin and Marty sites and along the entire study reach from August 23 to 27, 2015, Johnson County, Kansas.

minimum detection threshold $(0.1 \mathrm{mg} / \mathrm{L})$ upstream from the Middle Basin WWTF to a maximum of $10.8 \mathrm{mg} / \mathrm{L}$ approximately $3.6 \mathrm{~km}$ downstream from the Middle Basin WWTF, approximately $0.8 \mathrm{~km}$ farther downstream than the peak of $11.2 \mathrm{mg} / \mathrm{L}$ observed during the first survey (fig. 11C). Nitrate concentrations did not increase steadily downstream to the maximum. As observed in the first survey, nitrate concentrations increased from immediately downstream from the WWTF to approximately $1.4 \mathrm{~km}$ downstream, though the location was offset slightly downstream and the change in concentration (from $10.0 \mathrm{mg} / \mathrm{L}$ to $10.4 \mathrm{mg} / \mathrm{L}$, a rate of change of about $0.3 \mathrm{mg} / \mathrm{L} / \mathrm{km}$ ) was lower than observed during the first survey. Nitrate concentrations rapidly decreased by $0.3 \mathrm{mg} / \mathrm{L}$ (from 10.4 to $10.1 \mathrm{mg} / \mathrm{L}$ ) slightly downstream from the confluence with Tributary 1, increased by $0.2 \mathrm{mg} / \mathrm{L}$ over the next $0.4 \mathrm{~km}$ (from
10.1 to $10.3 \mathrm{mg} / \mathrm{L}$ ), and then decreased by $0.4 \mathrm{mg} / \mathrm{L}$ (from 10.3 to $9.9 \mathrm{mg} / \mathrm{L}$ ) over the next $0.9 \mathrm{~km}$ before rapidly increasing (at a rate of change of about $1.28 \mathrm{mg} / \mathrm{L} / \mathrm{km}$ ) to the observed maximum of $10.8 \mathrm{mg} / \mathrm{L}$ (fig. 11C). Nitrate concentrations decreased steadily from approximately $3.6 \mathrm{~km}$ downstream from the Middle Basin WWTF to the confluence with Tomahawk Creek, but concentrations decreased more rapidly from approximately $9.1 \mathrm{~km}$ downstream to the confluence with Tomahawk Creek (from 6.7 to $4.3 \mathrm{mg} / \mathrm{L}$, a rate of change of about $1.1 \mathrm{mg} / \mathrm{L} / \mathrm{km}$ ), than between $3.6 \mathrm{~km}$ and $9.1 \mathrm{~km}$ downstream (from 10.8 to $6.7 \mathrm{mg} / \mathrm{L}$, a rate of change of about $0.7 \mathrm{mg} / \mathrm{L} / \mathrm{km}$ ) (fig. $11 \mathrm{C}$ ). This pattern in decrease is shifted downstream by approximately $0.5 \mathrm{~km}$ relative to what was observed during the first survey, but the concentrations and rates of change are nearly identical. At the confluence with Tomahawk Creek, nitrate concentrations 

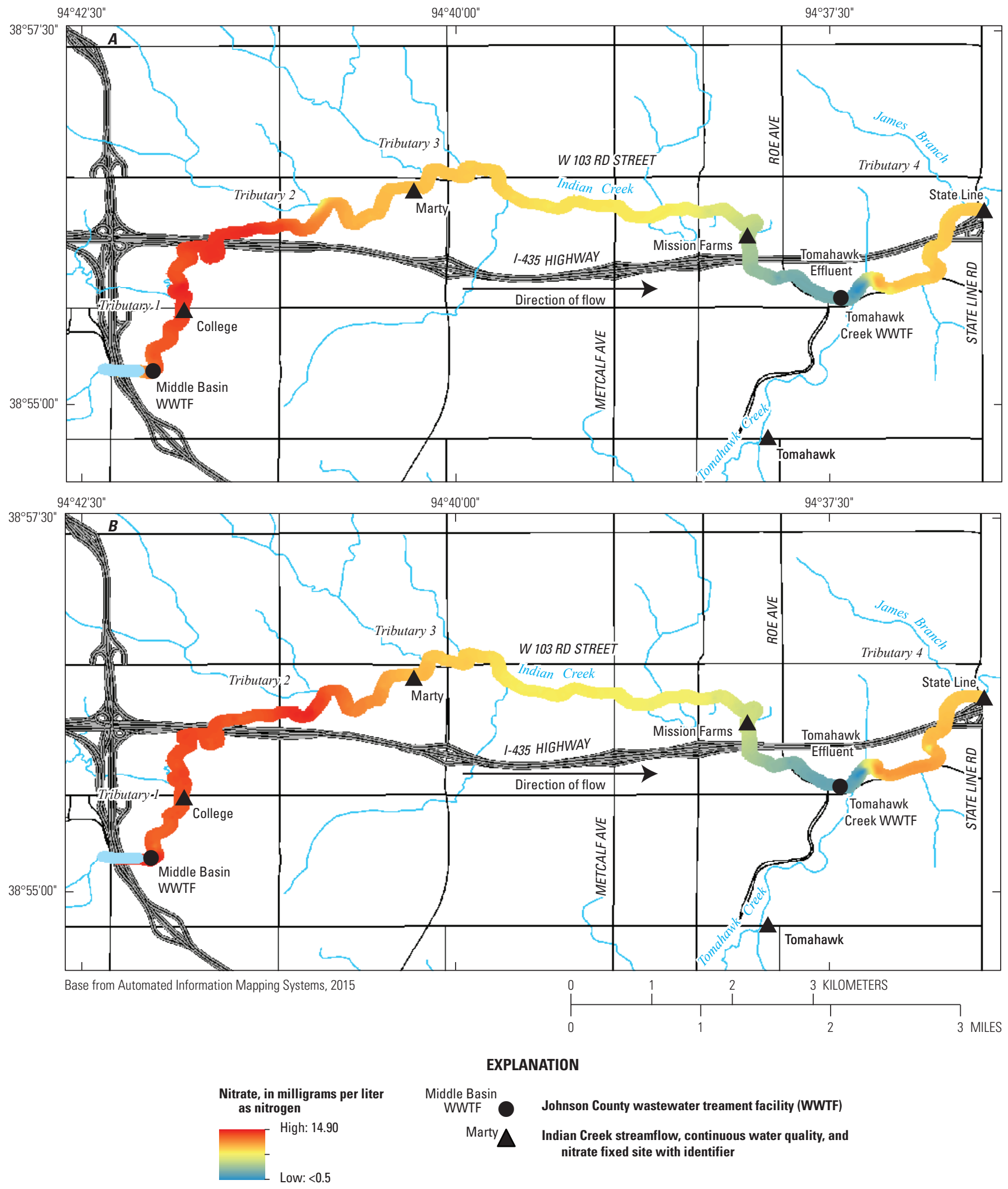

Figure 11. Nitrate plus nitrite (as nitrogen) and orthophosphorus (as phosphorus) data along the study reach on August 26, 2015, Johnson County, Kansas. A, survey 1 sensor-measured nitrate plus nitrite concentrations (as nitrogen); $B$, map of August 26, 2015 survey 2 sensor-measured nitrate plus nitrite concentrations (as nitrogen); $C$, cumulative difference in nitrate plus nitrite concentrations (as nitrogen) along the study reach; $D$, survey 1 discrete sample orthophosphorus concentrations (as phosphorus); $E$, survey 2 discrete sample orthophosphorus concentrations (as phosphorus); and $F$, cumulative difference in orthophosphorus concentration (as phosphorus). 


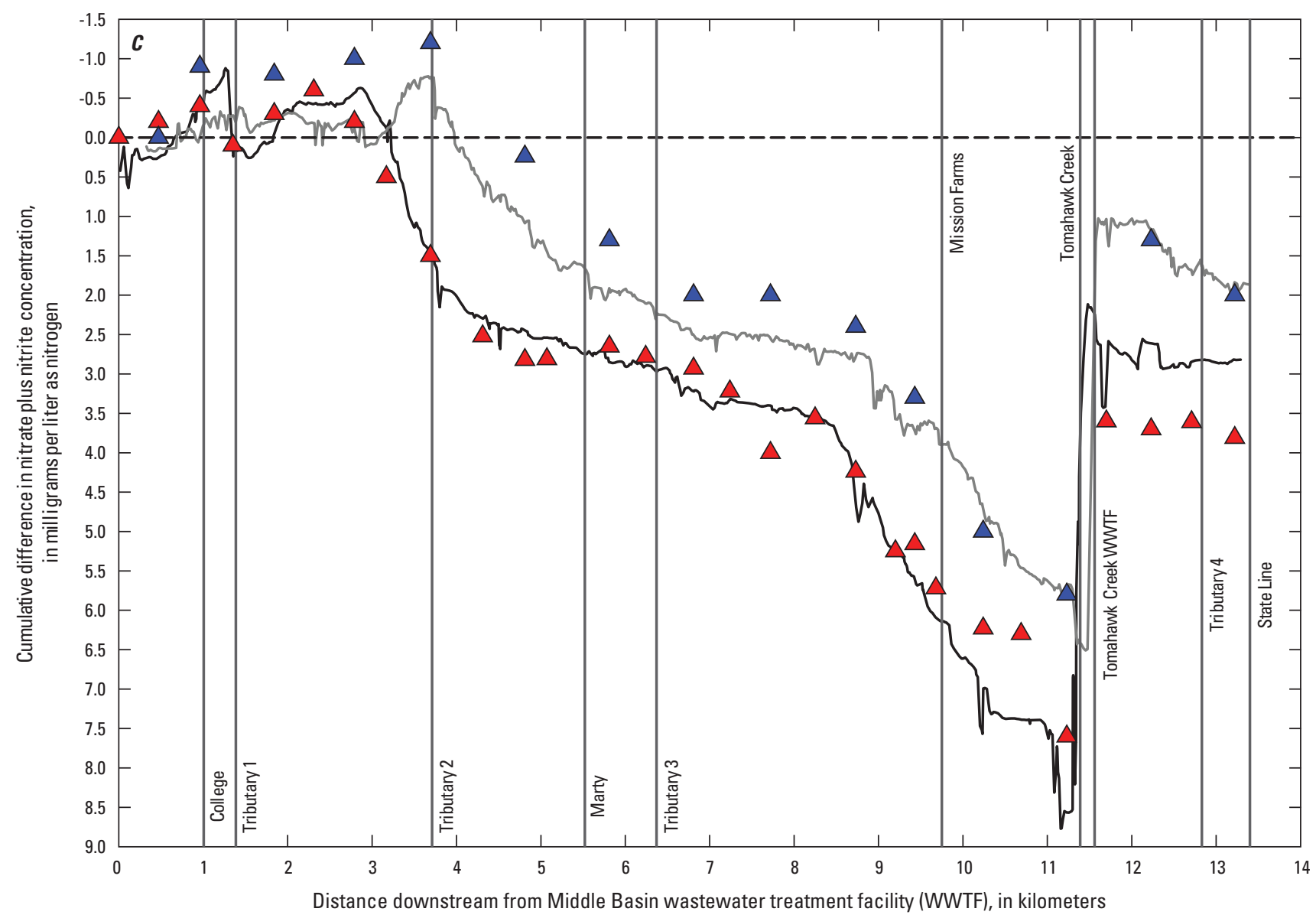

EXPLANATION

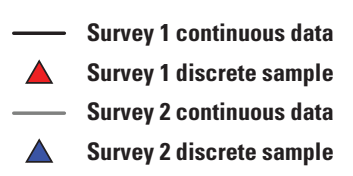

Figure 11. Nitrate plus nitrite (as nitrogen) and orthophosphorus (as phosphorus) data along the study reach on August 26, 2015, Johnson County, Kansas. $A$, survey 1 sensor-measured nitrate plus nitrite concentrations (as nitrogen); $B$, map of August 26, 2015 survey 2 sensor-measured nitrate plus nitrite concentrations (as nitrogen); $C$, cumulative difference in nitrate plus nitrite concentrations (as nitrogen) along the study reach; $D$, survey 1 discrete sample orthophosphorus concentrations (as phosphorus); $E$, survey 2 discrete sample orthophosphorus concentrations (as phosphorus); and $F$, cumulative difference in orthophosphorus concentration (as phosphorus).-Continued 

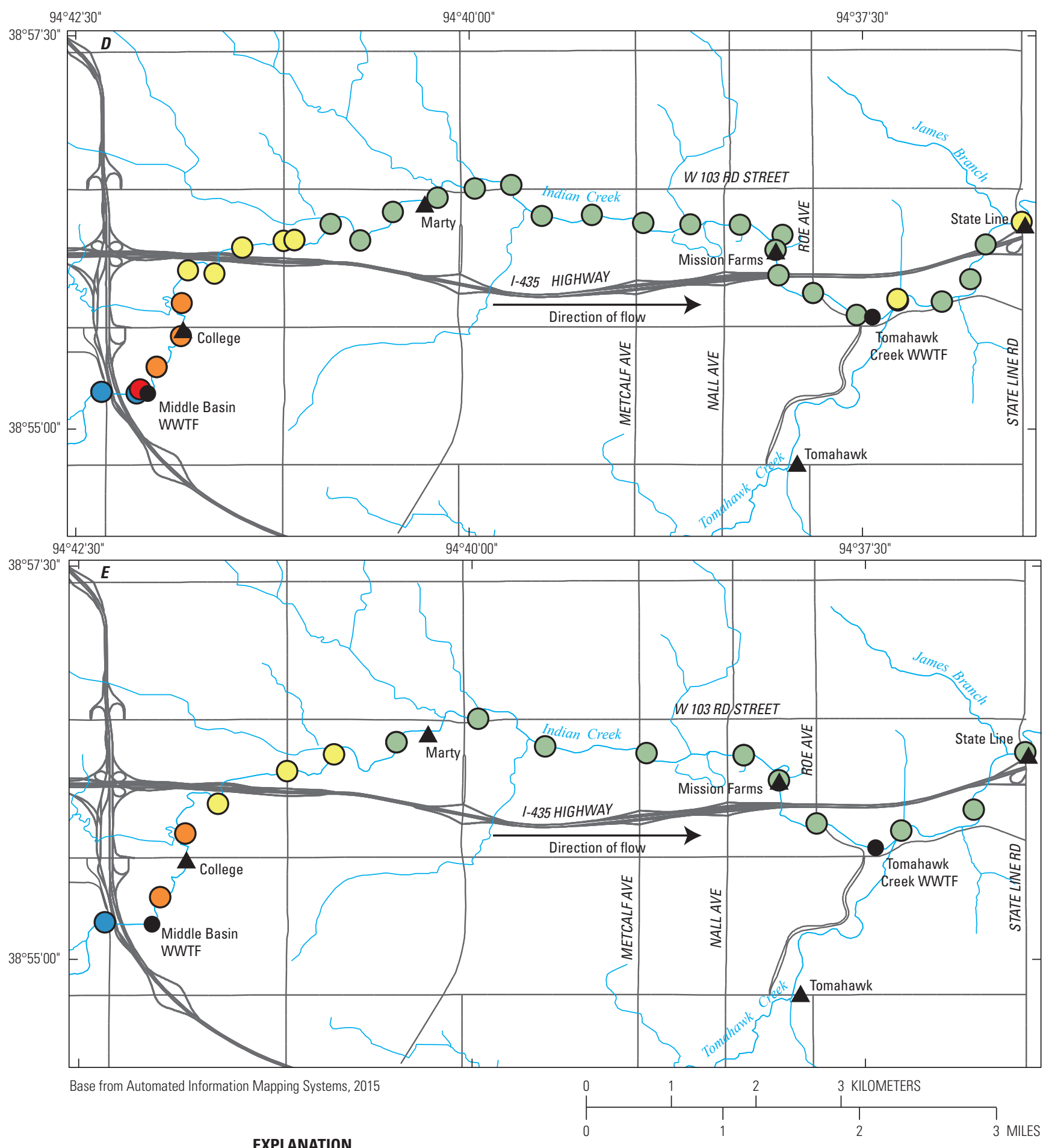

\begin{tabular}{|c|c|c|}
\hline $\begin{array}{l}\text { Orthophosphorus, in } \\
\text { milligrams per } \\
\text { liter as phosphorus }\end{array}$ & $\begin{array}{l}\text { Middle Basin } \\
\text { WWTF }\end{array}$ & $\begin{array}{l}\text { Johnson County } \\
\text { wastewater } \\
\text { treament } \\
\text { facility (WWTF) }\end{array}$ \\
\hline$<0.05$ & \multirow{5}{*}{ Marty } & Indian Creek \\
\hline 0.06 to 1.00 & & streamflow, \\
\hline 1.01 to 1.57 & & continuous \\
\hline 1.58 to 2.11 & & and nitrate fixed \\
\hline 2.12 to 2.84 & & site with identifier \\
\hline
\end{tabular}

Figure 11. Nitrate plus nitrite (as nitrogen) and orthophosphorus (as phosphorus) data along the study reach on August 26, 2015, Johnson County, Kansas. $A$, survey 1 sensor-measured nitrate plus nitrite concentrations (as nitrogen); $B$, map of August 26, 2015 survey 2 sensor-measured nitrate plus nitrite concentrations (as nitrogen); $C$, cumulative difference in nitrate plus nitrite concentrations (as nitrogen) along the study reach; $D$, survey 1 discrete sample orthophosphorus concentrations (as phosphorus); $E$, survey 2 discrete sample orthophosphorus concentrations (as phosphorus); and $F$, cumulative difference in orthophosphorus concentration (as phosphorus).-Continued 


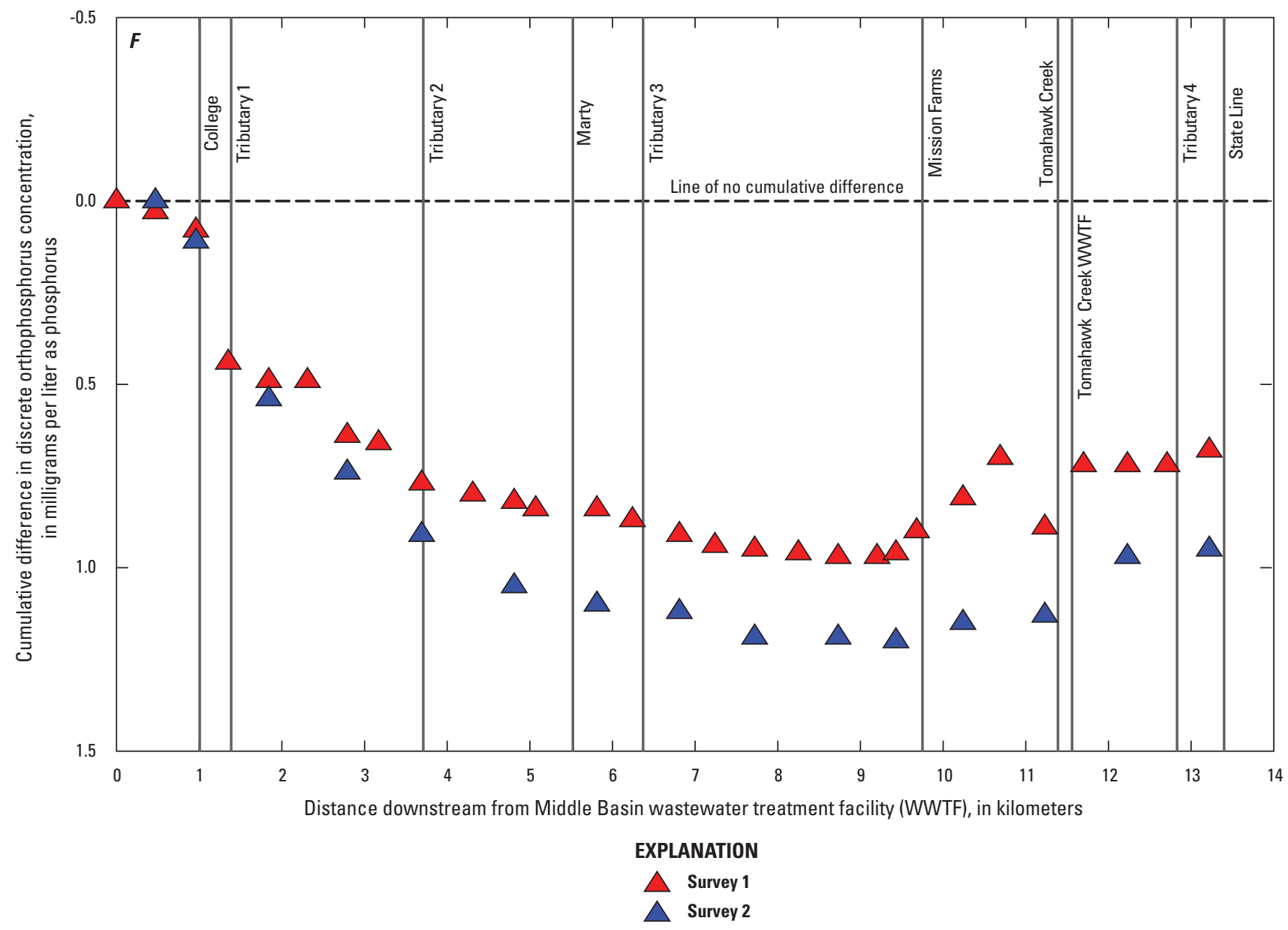

Figure 11. Nitrate plus nitrite (as nitrogen) and orthophosphorus (as phosphorus) data along the study reach on August 26, 2015, Johnson County, Kansas. A, survey 1 sensor-measured nitrate plus nitrite concentrations (as nitrogen); $B$, map of August 26, 2015 survey 2 sensor-measured nitrate plus nitrite concentrations (as nitrogen); $C$, cumulative difference in nitrate plus nitrite concentrations (as nitrogen) along the study reach; $D$, survey 1 discrete sample orthophosphorus concentrations (as phosphorus); $E$, survey 2 discrete sample orthophosphorus concentrations (as phosphorus); and $F$, cumulative difference in orthophosphorus concentration (as phosphorus).-Continued

dropped rapidly (about $5.0 \mathrm{mg} / \mathrm{L} / \mathrm{km}$ ) to a downstream minimum of $3.5 \mathrm{mg} / \mathrm{L}$. The downstream minimum observed during the second survey was $1.5 \mathrm{mg} / \mathrm{L}$ higher than observed during the first survey, possibly because of the low-concentration parcel of water moving downstream from the Tomahawk Creek WWTF, incomplete mixing at the confluence of Indian and Tomahawk Creeks, or the paths the two surveys traveled through that area. Nitrate concentrations increased by $5.5 \mathrm{mg} / \mathrm{L}$ (from 3.5 to $9.0 \mathrm{mg} / \mathrm{L}$ ) immediately downstream from the Tomahawk Creek WWTF (fig. 11B, C). As observed during the first survey, nitrate concentrations downstream from the Tomahawk Creek WWTF decreased at a slower rate of change than observed elsewhere along the study reach (about $0.6 \mathrm{mg} / \mathrm{L} / \mathrm{km}$ ) to a concentration of $8.1 \mathrm{mg} / \mathrm{L}$ at the State Line site.
As observed in 2014, changes in discrete orthophosphorus concentrations along the study reach on August 26, 2015, were not as pronounced as nitrate concentrations (fig. $11 D-F$ ). Although data were collected at a higher resolution during the first survey (every $0.5 \mathrm{~km}$ ) than the second survey (every $1.0 \mathrm{~km}$ ), patterns and concentrations observed along the upstream-downstream gradient were similar. Cumulative differences in concentration appear greater during the second survey because of the lower frequency in discrete-sample collection (fig. $11 F$ ). Orthophosphorus concentrations ranged from less than the laboratory reporting level $(0.05 \mathrm{mg} / \mathrm{L})$ upstream from the Middle Basin WWTF to maxima of between $1.7 \mathrm{mg} / \mathrm{L}$ (first survey) and $1.9 \mathrm{mg} / \mathrm{L}$ (second survey) immediately downstream from the Middle Basin WWTF (fig. 11D, E). Orthophosphorus 
concentrations decreased steadily at a rate of change of about $0.1 \mathrm{mg} / \mathrm{L} / \mathrm{km}$ from approximately $0.5 \mathrm{~km}$ downstream from the Middle Basin WWTF to just upstream from the Mission Farms site (approximately $9.7 \mathrm{~km}$ downstream), where the downstream minimum of $0.7 \mathrm{mg} / \mathrm{L}$ was observed during both surveys. Orthophosphorus concentrations increased by $0.3 \mathrm{mg} / \mathrm{L}$ (from 0.7 to $1.0 \mathrm{mg} / \mathrm{L}$ ) between $9.7 \mathrm{~km}$ and $10.7 \mathrm{~km}$ downstream from the Middle Basin WWTF, then decreased by $0.2 \mathrm{mg} / \mathrm{L}$ (from 1.0 to 0.8 ) at the confluence with Tomahawk Creek (fig. $11 F$ ); the lower-frequency discrete-sample collection during the second survey did not capture this change. Orthophosphorus concentrations increased by $0.2 \mathrm{mg} / \mathrm{L}$ (from $0.8 \mathrm{mg} / \mathrm{L}$ to $1.0 \mathrm{mg} / \mathrm{L}$ ) immediately downstream from the Tomahawk Creek WWTF. Orthophosphorus concentration did not change between the Tomahawk Creek WWTF and the State Line site (fig. 11D-F).

\section{Temporally Dense Nitrate Data at Six Fixed Sites}

Sensor-measured nitrate data were collected every 15 minutes at five sites on Indian Creek and one site on Tomahawk Creek from March 2012 through June 2013. Two sites (119th and Tomahawk) were located upstream from WWTFs, three sites (College, Marty, and Mission Farms) were located downstream from the Middle Basin WWTF, and one site (State Line) was located downstream from the Middle Basin and Tomahawk Creek WWTFs (fig. 1). These sensor-measured nitrate data were used to describe the broad changes in nitrate concentrations along the upstream-downstream gradient in Indian Creek by Graham and others (2014), but temporal variability in nitrate concentrations was not evaluated. In the following sections, the 2012 to 2013 sensor-measured nitrate data are used to describe the spatial and temporal (cyclical and seasonal) variability in nitrate concentrations.

\section{Spatial Variability in Nitrate Concentrations}

The two sites located upstream from the WWTFs had low average nitrate concentrations and instantaneous loads at below-normal, normal, and above-normal streamflow conditions (fig. 12A, B). Average nitrate concentrations at the 119th site, located approximately $2.4 \mathrm{~km}$ upstream from the Middle Basin WWTF, were $0.2 \mathrm{mg} / \mathrm{L}$ (range: less than 0.1 to $2.2 \mathrm{mg} / \mathrm{L}$ ) at below-normal streamflows, $0.7 \mathrm{mg} / \mathrm{L}$ (range: less than 0.1 to $3.7 \mathrm{mg} / \mathrm{L}$ ) at normal streamflows, and $1.4 \mathrm{mg} / \mathrm{L}$ (range: less than 0.1 to $3.3 \mathrm{mg} / \mathrm{L}$ ) at above-normal streamflows. Similarly, at the Tomahawk Creek site, located approximately $2.6 \mathrm{~km}$ upstream from the Tomahawk Creek WWTF, average nitrate concentrations were $0.2 \mathrm{mg} / \mathrm{L}$ (range: less than 0.1 to $0.7 \mathrm{mg} / \mathrm{L}$ ), $0.6 \mathrm{mg} / \mathrm{L}$ (range: less than 0.1 to $2.3 \mathrm{mg} / \mathrm{L}$ ), and $1.4 \mathrm{mg} / \mathrm{L}$ (range: less than 0.1 to $3.6 \mathrm{mg} / \mathrm{L}$ ) at below-normal, normal, and above-normal streamflows, respectively (fig. 12A). The College and State Line sites, located immediately downstream from the Middle Basin and
Tomahawk Creek WWTFs (fig. 1), respectively, had the highest average nitrate concentrations across nearly all streamflow conditions (the Marty site has slightly higher average nitrate concentrations than the State Line site at above-normal flows). Downstream from the Middle Basin WWTF, average nitrate concentrations consistently decreased with increasing distance downstream. During below-normal streamflows, when streamflow conditions were dominated by effluent (Graham and others, 2014), the average nitrate concentration was $8.8 \mathrm{mg} / \mathrm{L}$ (range: 2.3 to $13.7 \mathrm{mg} / \mathrm{L}$ ) at the College site (located approximately $1.1 \mathrm{~km}$ downstream from the Middle Basin WWTF), $7.4 \mathrm{mg} / \mathrm{L}$ (range: 2.0 to $10.3 \mathrm{mg} / \mathrm{L}$ ) at the Marty site (located approximately $5.5 \mathrm{~km}$ downstream), and $6.5 \mathrm{mg} / \mathrm{L}$ (range: 1.4 to $10.0 \mathrm{mg} / \mathrm{L}$ ) at the Mission Farms site (located approximately $9.8 \mathrm{~km}$ downstream from the Middle Basin WWTF; fig. 12A). On average, nitrate concentrations decreased by about $1.4 \mathrm{mg} / \mathrm{L}$ between the College and Marty sites (a rate of change of $0.3 \mathrm{mg} / \mathrm{L} / \mathrm{km}$ ), about $0.9 \mathrm{mg} / \mathrm{L}$ between the Marty and Mission Farms sites (a rate of change of $0.2 \mathrm{mg} / \mathrm{L} / \mathrm{km}$ ), and about $2.3 \mathrm{mg} / \mathrm{L}$ (a rate of change of $0.3 \mathrm{mg} / \mathrm{L} / \mathrm{km}$ ) overall along the entire reach (College to Mission Farms) during below-normal streamflow conditions. A similar among-site pattern was observed during normal streamflow conditions, with average nitrate concentrations decreasing by $1.1 \mathrm{mg} / \mathrm{L}$ between the College $(7.4 \mathrm{mg} / \mathrm{L})$ and Marty $(6.3 \mathrm{mg} / \mathrm{L})$ sites (a rate of change of $0.3 \mathrm{mg} / \mathrm{L} / \mathrm{km}$ ) and the Marty and Mission Farms $(5.2 \mathrm{mg} / \mathrm{L}$ ) sites (a rate of change of $0.2 \mathrm{mg} / \mathrm{L} / \mathrm{km}$ ). Overall, along the entire reach (College to Mission Farms) during normal streamflow conditions, average nitrate concentrations decreased $2.2 \mathrm{mg} / \mathrm{L}$ (a rate of change of $0.3 \mathrm{mg} / \mathrm{L} / \mathrm{km}$ ). Decreases in average nitrate concentrations along the upstream-downstream gradient were more subtle during above-normal streamflow conditions, with average concentrations decreasing from $3.9 \mathrm{mg} / \mathrm{L}$ at the College site to $2.8 \mathrm{mg} / \mathrm{L}$ at the Mission Farms site (fig. 12A). Nitrogen in wastewater effluent typically is inorganic and dissolved, and decreasing nitrate concentrations with increasing flow is indicative of the fact that the dominant source of nitrate in Indian Creek is effluent. At stream sites affected by wastewater effluent, concentrations of dissolved constituents typically decrease with increases in streamflow because of dilution (Welch and Lindell, 1992).

Though nitrate concentrations decreased along the upstream-downstream gradient across all streamflow conditions, instantaneous loads were similar at below-normal and normal streamflow conditions and increased at downstream sites during above-normal streamflows (fig. 12B). Above-normal streamflows in Indian Creek typically are caused by runoff events (Graham and others, 2014), and average above-normal streamflows increased in the downstream direction, from 91 $\mathrm{ft}^{3} / \mathrm{s}$ at the College site to $156 \mathrm{ft}^{3} / \mathrm{s}$ at the Mission Farms site (fig. 12C). Higher streamflows, and likely contribution of watershed nutrient sources in addition to wastewater effluent, resulted in higher overall nitrate loads during above-normal streamflow conditions. During above-normal streamflow conditions, average instantaneous nitrate loads were similar 

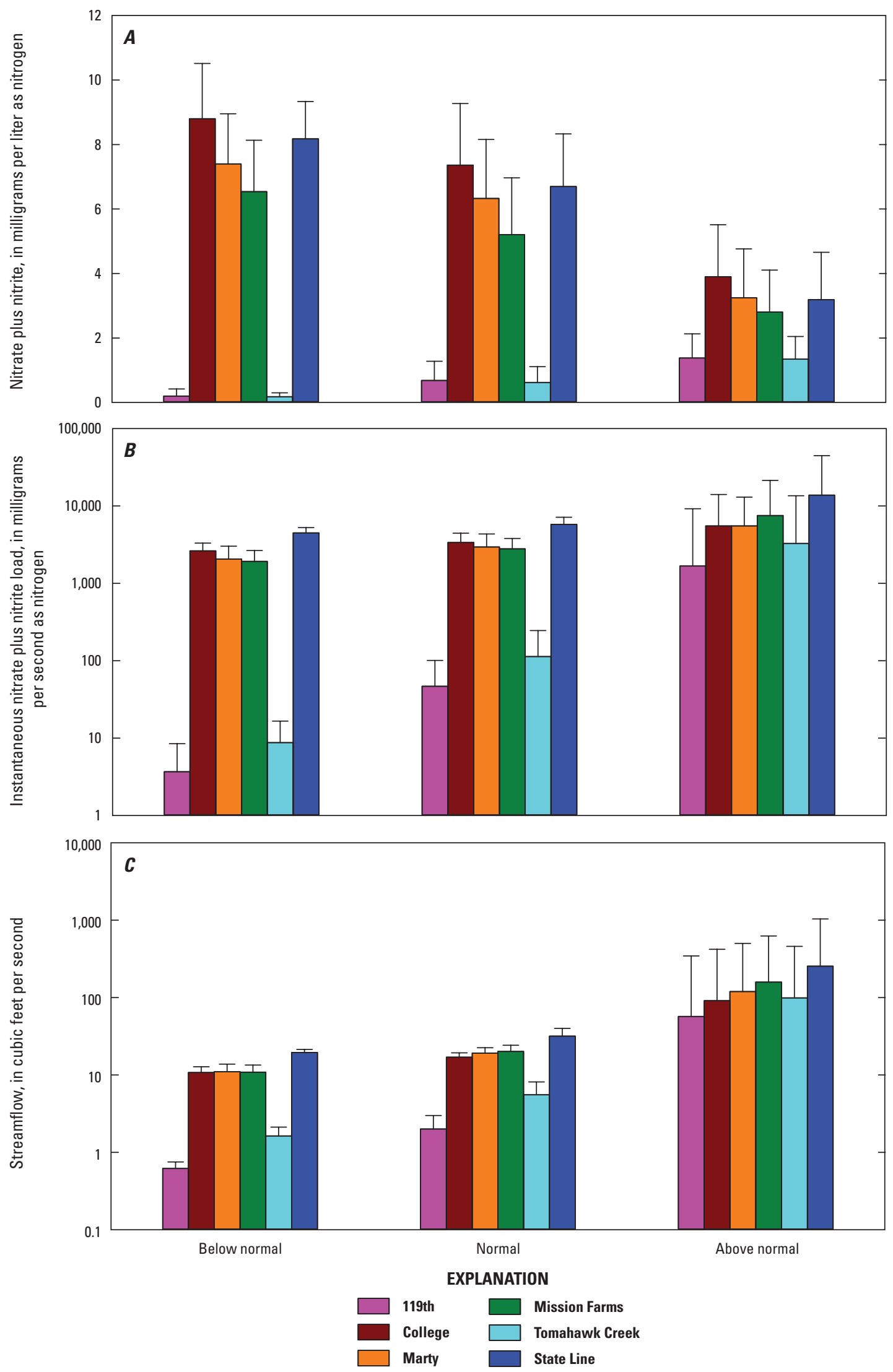

Figure 12. Average and standard deviation of $A$, nitrate plus nitrite concentration (as nitrogen); $B$, instantaneous nitrate plus nitrite load (as nitrogen); and $C$, streamflow at the Indian Creek study sites during March 2012 through June 2013, Johnson County, Kansas. 
between the College $(5,530 \mathrm{mg} / \mathrm{s})$ and Marty $(5,535 \mathrm{mg} / \mathrm{s})$ sites, but increased by about $2,020 \mathrm{mg} / \mathrm{s}$ between the Marty and Mission Farms sites (7,550 mg/s) (fig. 12B).

Indian Creek streamflow during below-normal and normal streamflows is dominated (typically greater than 85 percent) by wastewater effluent (Graham and others, 2014). Average streamflows between the College and Mission Farms sites were similar at below-normal (about $11 \mathrm{ft}^{3} / \mathrm{s}$ ) and normal (17 to $20 \mathrm{ft}^{3} / \mathrm{s}$ ) streamflow conditions, and Indian Creek gained little additional streamflow from tributaries and lost little streamflow to groundwater (fig. 12C). Because of the emphasis on spatiotemporal variability in nutrients caused by wastewater effluent, the focus of the remainder of the temporally dense data analysis is on nitrate concentrations during below-normal and normal streamflow conditions that are dominated by wastewater effluent.

\section{Cyclical Variability in Nitrate Concentrations}

Biological and other in-stream processes may cause diurnal variability in nitrate concentrations (Pellerin and others, 2009; Heffernan and Cohen, 2010). At the upstream 119th and Tomahawk Creek sites, nitrate concentrations varied by $0.1 \mathrm{mg} / \mathrm{L}$ on average during below-normal and normal streamflow conditions, with differences as large as $1.6 \mathrm{mg} / \mathrm{L}$ observed over a 24-hour period (fig. 13). Data in urban streams with a similar temporal resolution are unavailable for comparison; however, this range in variability is about $1 \mathrm{mg} / \mathrm{L}$ higher than the diurnal variation reported in a Florida spring and reported in California streams without direct wastewater effect (Pellerin and others, 2009; Heffernan and Cohen, 2010). The biological and chemical processes involved in nutrient removal at the Middle Basin WWTF may cause cyclical variability in effluent nutrient concentrations that translates to receiving waters (Henze and others, 2002). Cyclical variability was observed directly in the Middle Basin WWTF effluent during the spatial surveys, with differences as high as $6.0 \mathrm{mg} / \mathrm{L}$ over a 24-hour period; these differences directly affected nitrate concentrations and the magnitude of variability downstream (figs. 5, 7, and 10). At the downstream sites during March 2012 through June 2013, nitrate concentrations varied, on average, by 1.3 to $2.4 \mathrm{mg} / \mathrm{L}$ during below-normal and normal streamflow conditions. The highest variability was observed at the College site, located immediately downstream from the Middle Basin WWTF, with differences as large as $5.7 \mathrm{mg} / \mathrm{L}$ (average $2.4 \mathrm{mg} / \mathrm{L}$ ) occurring over a 24-hour period. Variability decreased with increasing distance downstream from the WWTF; cyclical variability averaged $1.6 \mathrm{mg} / \mathrm{L}$ at the Marty site and $1.3 \mathrm{mg} / \mathrm{L}$ at the Mission Farms site (fig. 13). The decrease in cyclical variability along the upstream-downstream gradient likely reflects the decrease in overall nitrate concentrations and lessening effect of the WWTF with increased distance downstream (figs. $12 A$ and 13 ). The cyclical variability in nitrate concentrations at the downstream Indian Creek sites is caused directly by the WWTF effect, likely masking any effects caused by biological and other in-stream processes.

\section{Reach-to-Reach Differences in Nitrate Concentrations}

The variability in Indian Creek nitrate concentrations caused by the Middle Basin WWTF (figs. 5, 7, 10, and 13) generated pulses in peak nitrate concentrations that were tracked downstream and used to generally describe decreases in nitrate concentrations along the study reach caused by dilution and other in-stream processes. Using the "Nitrate Pulse Analysis" described in the "Methods" section of this report (fig. 4), peaks from nitrate cycles during below-normal and normal streamflow conditions were aligned to quantify among-site differences in maximum nitrate concentrations; a total of 146 pulses were included in the analysis. The focus of this analysis was the reach between the College and Mission Farms sites, because the Tomahawk Creek WWTF caused increases in nitrate concentrations at the State Line site and masked the signal from the Middle Basin WWTF (fig. 12A). Maximum concentrations were highest at the College site, immediately downstream from the Middle Basin WWTF. Maximum concentrations at the College site were as high as $13.7 \mathrm{mg} / \mathrm{L}$, with 68 percent of maxima $(n=146)$ between 8.0 and $11.0 \mathrm{mg} / \mathrm{L}$ (fig. 14A). At the Marty and Mission Farms sites, maxima never exceeded $10.5 \mathrm{mg} / \mathrm{L}$. Seventy-seven percent $(n=146)$ of the maxima at the Marty site were between 7.0 and $10.0 \mathrm{mg} / \mathrm{L}$, and 73 percent were between 6 and $9 \mathrm{mg} / \mathrm{L}$ at the Mission Farms site (fig 14A).

Along the $8.7-\mathrm{km}$ study reach between the College and Mission Farms sites (fig. 1), nitrate concentrations in aligned peaks decreased by a range of 0.7 to $3.6 \mathrm{mg} / \mathrm{L}$. About 62 percent of decreases were between 2.01 and $2.75 \mathrm{mg} / \mathrm{L}$ (fig. 14B). On average, maximum nitrate concentrations decreased by $2.3 \mathrm{mg} / \mathrm{L}$, or by about 24 percent, along the $8.7-\mathrm{km}$ study reach (table 3 ). The average rate of decrease in maxima along the study reach was about $0.3 \mathrm{mg} / \mathrm{L} / \mathrm{km}$. These values match the decreases and rates observed for average nitrate concentrations at below-normal and normal streamflows for these sites (fig. 12A). Decreases along the reach were significantly, although weakly, correlated with initial nitrate concentration at the upstream College site (Spearman rank-correlation coefficient (rho) $=0.40, p$-value less than $0.01, n=146$ ), but not the percentage of streamflow contributed by WWTF effluent (rho $=-0.05, p=0.56, n=146$ ).

Overall, decreases in maximum nitrate concentration were similar between the College and Marty sites (upper reach), a reach of approximately $4.4 \mathrm{~km}$, and the Marty and Mission Farms sites (lower reach), a reach of approximately $4.3 \mathrm{~km}$. In the upper reach, maximum nitrate concentrations decreased by a range of 0.3 to $3.0 \mathrm{mg} / \mathrm{L}$, with about 75 percent of decreases between 0.76 and $1.50 \mathrm{mg} / \mathrm{L}$. Maximum nitrate concentrations decreased by less than 0.10 to $1.7 \mathrm{mg} / \mathrm{L}$ in the lower reach, with 68 percent of decreases between 0.76 and $1.50 \mathrm{mg} / \mathrm{L}$ (fig. 14B). Though most decreases along the upper and lower reaches were within the same range, the upper reach had the highest amount of decreases in the $0.76-1.00 \mathrm{mg} / \mathrm{L}$ range (31 percent) and the lower reach had 


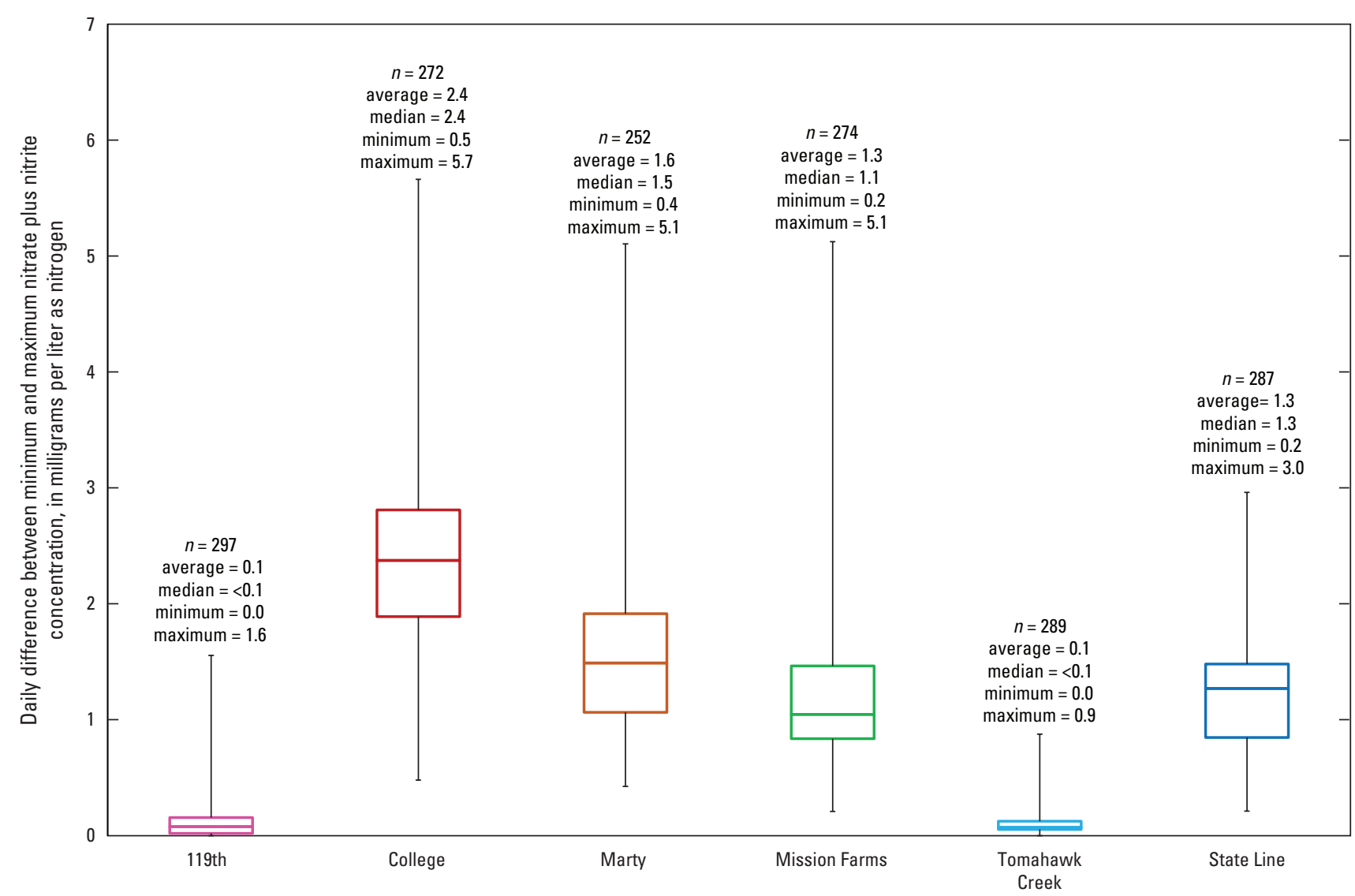

EXPLANATION

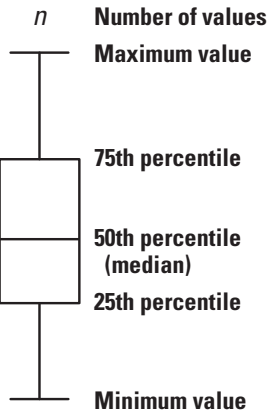

Figure 13. Box plots and summary statistics of cyclical variability during a 24-hour period in nitrate plus nitrite concentrations (as nitrogen) at Indian Creek, Kansas, study sites from March 2012 through June 2013.

the highest amount of decreases in the $1.26-1.50 \mathrm{mg} / \mathrm{L}$ range (28 percent) (fig. 14B). On average, maximum nitrate concentrations decreased by $1.2 \mathrm{mg} / \mathrm{L}$ and $1.0 \mathrm{mg} / \mathrm{L}$ in the upper and lower reaches, respectively; maximum nitrate concentrations decreased by about 13 percent, on average, along both reaches (table 3). Average rates of decrease were 0.3 and $0.2 \mathrm{mg} / \mathrm{L} / \mathrm{km}$ along the upper and lower reaches, respectively. These values generally match the decreases and rates observed for average nitrate concentrations at below-normal and normal streamflows (fig. 12A). Decreases along the upper reach were significantly, and positively, correlated with initial nitrate concentration at the College site (rho $=0.59, p$-value less than $0.01, n=146$ ), indicating that higher decreases in nitrate were associated with higher initial nitrate concentrations. A similar relation was not observed along the lower reach. Initial nitrate concentration at the Marty site was not significantly correlated with decreases in nitrate concentration along the reach (rho $=-0.16, p$-value $=0.05, n=146)$. Decreases in nitrate concentration were not significantly correlated with the percentage of streamflow contributed by WWTF effluent along either reach (upper reach: $\mathrm{rho}=0.04, p=0.62, n=146$; lower reach: rho $=-0.09, p=0.28, n=146$ ). 


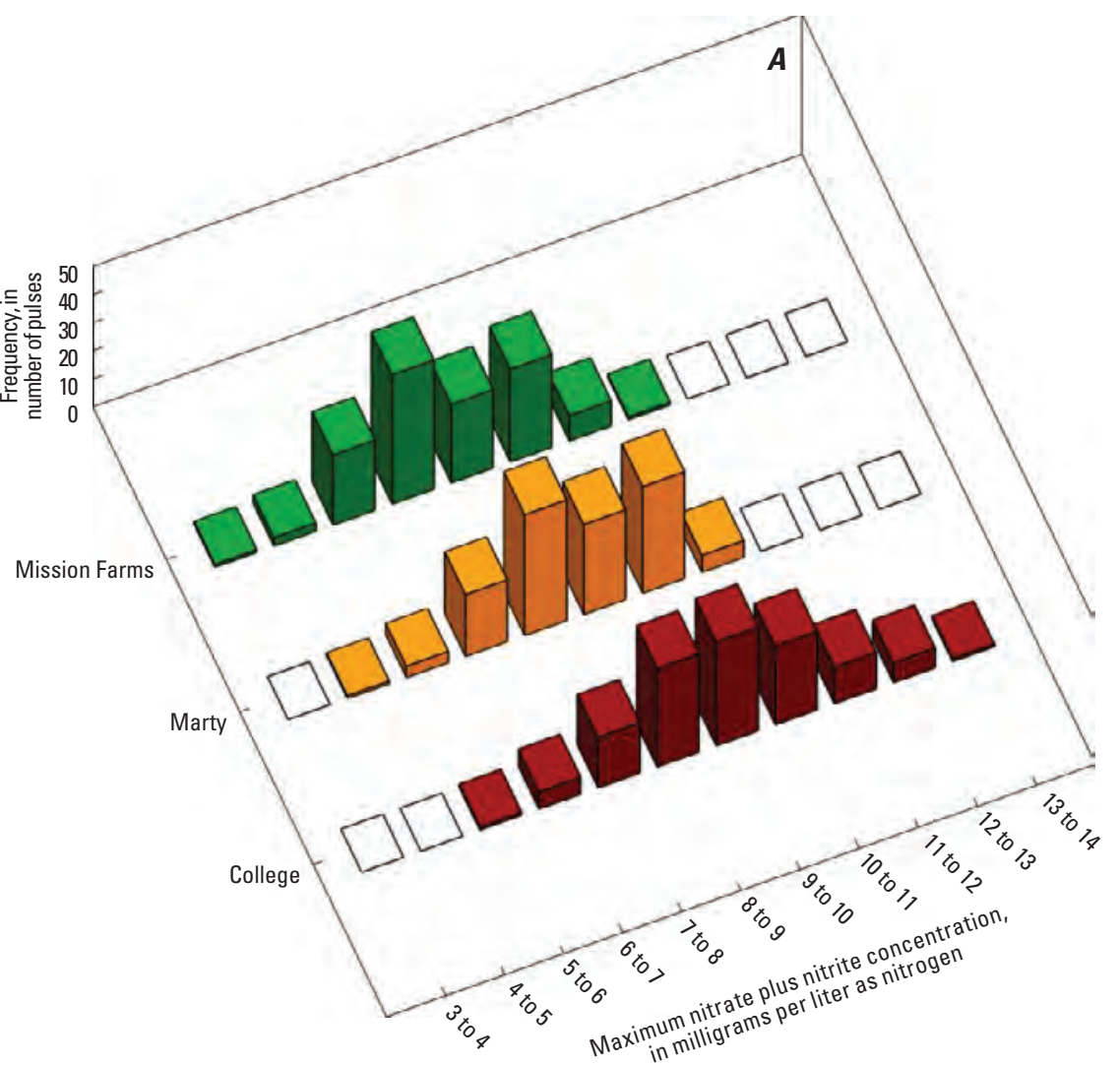

Figure 14. Frequency distribution and differences in nitrate plus nitrite concentrations (as nitrogen). $A$, maximum nitrate plus nitrite (pulse) concentrations (as nitrogen) at the College, Marty, and Mission Farms sites and $B$, differences in nitrate plus nitrite (pulse) concentrations (as nitrogen) between sites, during March 2012 through June 2013. 
Table 3. Summary statistics of decrease and percent decrease in maximum nitrate plus nitrite concentrations (as nitrogen) along the Indian Creek, Kansas, reach between College, Marty, and Mission Farms study sites during March 2012 through June 2013.

[mg/L, milligram per liter]

\begin{tabular}{|c|c|c|c|c|c|c|}
\hline & \multicolumn{2}{|c|}{ College to Marty } & \multicolumn{2}{|c|}{ Marty to Mission Farms } & \multicolumn{2}{|c|}{ College to Mission Farms } \\
\hline & $\begin{array}{c}\text { Change } \\
\text { in nitrate } \\
\text { plus nitrite } \\
\text { concentration } \\
\text { (mg/L) }\end{array}$ & $\begin{array}{l}\text { Percent } \\
\text { change }\end{array}$ & $\begin{array}{c}\text { Change } \\
\text { in nitrate } \\
\text { plus nitrite } \\
\text { concentration } \\
\text { (mg/L) }\end{array}$ & $\begin{array}{l}\text { Percent } \\
\text { change }\end{array}$ & $\begin{array}{l}\text { Change in nitrate } \\
\text { plus nitrite } \\
\text { concentration } \\
\text { (mg/L) }\end{array}$ & $\begin{array}{l}\text { Percent } \\
\text { change }\end{array}$ \\
\hline Average & 1.24 & 13.1 & 1.02 & 13.0 & 2.26 & 24.4 \\
\hline Median & 1.12 & 12.8 & 1.09 & 13.8 & 2.29 & 25.5 \\
\hline Minimum & 0.25 & 2.9 & 0.08 & 0.9 & 0.72 & 8.5 \\
\hline Maximum & 2.95 & 22.2 & 1.74 & 22.3 & 3.62 & 33.0 \\
\hline
\end{tabular}

Decreases in nitrate concentrations along the study reach may be caused by dilution. Tributary contributions to streamflow along the Indian Creek study reach between College and Mission Farms sites during March 2012 through June 2013 are uncertain because it was not directly measured, and daily variability in effluent discharge volume from the Middle Basin WWTF make identifying a clear signal of tributary effect at the gaging stations difficult. Major tributaries were, however, measured as part of the 2014 and 2015 spatial surveys. The maximum potential tributary input was 9 percent (tributary 3 ; fig. 1) in 2014. In 2015, the maximum potential tributary input was 4 percent (tributary 1; fig. 1). Although these are only two discrete points in time, data suggest that the tributary input is not consistent. Because of the small size of the contributing tributary basins and large percentage of impervious surface, tributary inputs likely are driven by urban effects. These available data points suggest that dilution plays a role in decreases in nitrate concentration along the study reach, although other factors such as sorption to and desorption from sediments, biological processes, or other in-stream processes also are important in decreased nitrate concentration along the study reach.

Time of year may affect decreases in nitrate concentration along the upstream-downstream gradient because streamflows affect dilution, and temperature, light, and other environmental factors effect in-stream processes that affect nutrient cycling (Allan, 1995). Seasonal patterns in maximum nitrate concentrations matched the overall among-site pattern in average and maximum nitrate concentrations (figs. 12A, 14A, 15A), with maxima decreasing with increasing distance downstream from the Middle Basin WWTF. The highest average maxima occurred in spring, and the lowest occurred in winter (fig. 15A). Despite this overall pattern, the maximum observed nitrate concentration $(13.3 \mathrm{mg} / \mathrm{L})$ occurred during summer and the minimum observed concentration occurred during fall $(3.6 \mathrm{mg} / \mathrm{L})$.
Along the study reach between College and Mission Farms, average decrease in maximum nitrate concentration did not vary substantially among seasons $(2.2$ to $2.4 \mathrm{mg} / \mathrm{L}$; fig. 15B). However, the pattern in average decrease between the upper and lower study reaches did differ by season. During spring and summer, decreases in nitrate concentration were 44 to 100 percent higher along the upper reach $(1.6$ and $1.3 \mathrm{mg} / \mathrm{L}$, respectively) than along the lower reach $(0.8$ and $0.9 \mathrm{mg} / \mathrm{L}$, respectively). In contrast, average decrease in maximum nitrate concentration was 30 percent higher along the lower reach $(1.3 \mathrm{mg} / \mathrm{L})$ than the upper reach $(1.0 \mathrm{mg} / \mathrm{L})$ in winter. Decreases along the upper and lower reaches were similar (1.2 and $1.1 \mathrm{mg} / \mathrm{L}$, respectively) during the fall (fig. $15 B$ ).

\section{Spatiotemporal Variability of Inorganic Nutrients in Indian Creek}

The cyclical variability in nitrate concentrations in the Middle Basin WWTF effluent substantially affected the spatial and temporal patterns observed in Indian Creek during the longitudinal surveys and at the fixed-site locations. Nitrate concentrations in the Middle Basin WWTF effluent and at downstream sites varied by as much as $6 \mathrm{mg} / \mathrm{L}$ over a 24-hour period (figs. 5, 7, 10, and 13). The cyclical variability in Middle Basin effluent generated a nitrate pulse that could be tracked for approximately $11.5 \mathrm{~km}$ downstream in Indian Creek, until the effect was masked by the Tomahawk Creek WWTF effluent discharge.

All four of the spatially dense longitudinal surveys showed the same general patterns along the upstream-downstream gradient, though streamflows $\left(10-69 \mathrm{ft}^{3} / \mathrm{s}\right)$, effluent contributions ( 38 to 100 percent) to streamflow, and nutrient concentrations (figs. 6, 8, 9, and 11) spanned a wide range. 

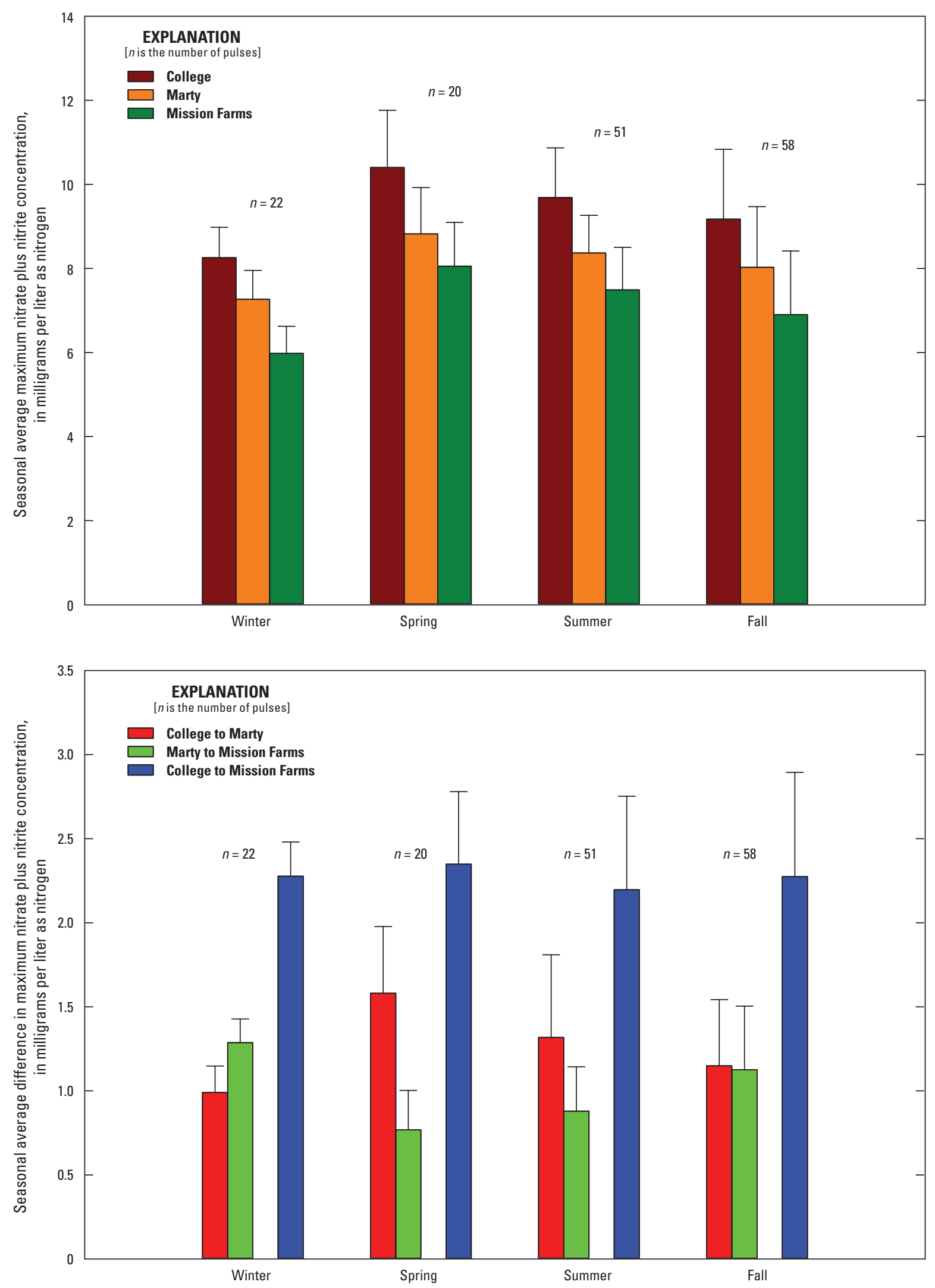

Figure 15. Seasonal average and standard deviation of nitrate plus nitrite data (as nitrogen) and nitrate plus nitrite concentration (as nitrogen) differences. $A$, maximum nitrate plus nitrite concentration (as nitrogen) at the College, Marty, and Mission Farms sites in Kansas, and $B$, differences in nitrate plus nitrite concentration (as nitrogen) between sites, during March 2012 through June 2013. 
With the exception of Tomahawk Creek, tributaries contributed small amounts of flow and nutrients to Indian Creek. Nutrient patterns observed along the upstream-downstream gradient during these surveys were largely affected by the WWTFs and the travel time of the parcels of water. In all surveys, nitrate concentrations initially decreased downstream from the Middle Basin WWTF, increased to a peak somewhere upstream from the Marty site, and decreased at varying rates to downstream minima at the confluence with Tomahawk Creek. Nitrate concentrations increased immediately downstream from the Tomahawk Creek WWTF and either decreased or varied little to the State Line site. The nitrate peaks encountered upstream from the Marty site reflect peaks in nitrate concentrations that occurred approximately 24 hours before at the Middle Basin WWTF. The magnitude and location of the nitrate peaks upstream from the Marty site depended on the peak concentrations observed at the Middle Basin WWTF and the time of day the surveys were performed (for example, figs. 10 and 11). The patterns and rates of change in nitrate concentrations downstream from the Marty site reflect peaks in nitrate concentrations that occurred approximately 48 to 72 hours before at the Middle Basin WWTF.

There were clear differences in orthophosphorus and nitrate patterns along the upstream-downstream gradient in Indian Creek, and orthophosphorus concentrations were not as variable as nitrate (figs. 8 and 11). In general, orthophosphorus concentrations decreased downstream from the Middle Basin WWTF to minima near the confluence with Tomahawk Creek, increased downstream from the Tomahawk Creek WWTF, and then varied little to the State Line site. Tomahawk Creek data indicated a clear dilution effect on nitrate, but not orthophosphorus, concentrations in Indian Creek. Orthophosphorus was not measured at the same spatial resolution as nitrate (every 0.5 to $1.0 \mathrm{~km}$ compared to sensor measurements at 30 -second intervals), and temporal variability was not quantified. Therefore, some of the differences in observed patterns may be due to differences in the way the two nutrients were measured. Differences also may be due to differences in the treatment processes for the two nutrients (Henze and others, 2002; Tchobanoglous and others, 2003) and differences in biological and other in-stream processing of the two nutrients (Allan, 1995).

Despite the marked variability in nitrate concentrations caused by the WWTF, patterns of decreasing nitrate concentrations were discernable along the upstream-downstream gradient using the fixed-site data collected from March 2012 through June 2013. Tracking pulse peaks (maxima) in nitrate concentration downstream allowed quantification of decreases in the same general parcel of water over time. Decreases in nitrate concentrations along the $8.7-\mathrm{km}$ study reach between College and Mission Farms sites were less variable (0.72$3.6 \mathrm{mg} / \mathrm{L}$ ) than the cyclical variability typically recorded along the same reach $(0.2-5.7 \mathrm{mg} / \mathrm{L}$ ) (figs. 13 and $14 A)$, reiterating the effect of the Middle Basin WWTF on the spatiotemporal variability of nitrate in Indian Creek.
On average, maximum nitrate concentrations decreased by about $2.3 \mathrm{mg} / \mathrm{L}$ between the College and Mission Farms sites (fig. 14B). Initial nitrate concentration was positively correlated with decreases, indicating higher initial concentrations resulted in greater decreases. For the College to Mission Farms reach, decreases in nitrate concentration were generally consistent across seasons (fig. 15B). By comparison, although decreases and rates of change in nitrate concentration were similar between the upper (College to Marty) and lower (Marty to Mission Farms) reaches, relations with initial nitrate concentrations and seasonal patterns were different between the two reaches and did not reflect patterns observed for the overall reach (figs. $14 B$ and $15 B$ ). Initial nitrate concentration was only correlated with decreases in the upper reach, suggesting initial concentrations were not as important in determining decreases in the lower reach. Seasonally, decreases were higher in the upper reach than the lower reach during spring and summer. In winter, differences were less pronounced, but were higher in the lower reach than the upper reach (fig. 15B).

Quantifying the decreases in nitrate concentration caused by dilution and other in-stream processes were beyond the scope of this study, and limited by available data. The data that are available suggest that dilution and other in-stream processes play a role in decreasing nitrate concentrations downstream from the Middle Basin WWTF in Indian Creek. In-stream processes that may cause decreases in nitrate concentrations include sorption to streambed sediments and biological processes (Allan, 1995). Graham and others (2014) determined that streambed-sediment nitrate concentrations were three orders of magnitude higher downstream from the Middle Basin WWTF than upstream, indicating nitrate losses to the sediment occur. Biological primary productivity production in Indian Creek was positively correlated with nitrate concentrations, and although rates varied seasonally, they consistently decreased in the downstream direction from the College to Mission Farms sites (Graham and others, 2014). However, establishing clear associations between primary production and nutrient concentrations is difficult, particularly when nutrients are abundant (Mulholland and others, 2001; Dodds and others, 1998).

Analysis of the spatiotemporal variability of nutrients in Indian Creek focused on below-normal and normal streamflow conditions, when streamflow and nutrient concentrations in Indian Creek were largely controlled by WWTF effluent flows and nutrient removal processes. Spatial and temporal data indicate there are decreases in nutrient concentrations along the upstream-downstream gradient in Indian Creek, but quantifying decreases are complicated by the variability in nutrient concentrations caused by the WWTFs. During below-normal and normal streamflow conditions, Indian Creek nutrient concentrations downstream from the Middle Basin WWTF primarily reflect effluent concentrations in the hours or days before depending on relative distance downstream. 


\section{Summary}

Nutrients, particularly nitrogen and phosphorus, are a leading cause of water-quality impairment in Kansas and the Nation. Understanding the variability of nitrogen and phosphorus in Kansas streams will help develop effective nutrient reduction strategies, watershed management plans, and best management practices. During 2011-13, the U.S. Geological Survey, in cooperation with Johnson County Wastewater, performed a study to assess the effects of wastewater effluent on the environmental and biological conditions of Indian Creek, Johnson County, Kansas. Indian Creek is one of the most urban drainage basins in Johnson County, Kansas, and environmental and biological conditions are affected by contaminants from point and other urban sources. The Johnson County Douglas L. Smith Middle Basin (hereinafter Middle Basin) wastewater treatment facility (WWTF) is the largest point-source discharge on Indian Creek. A second facility, the Tomahawk Creek WWTF, discharges into Indian Creek approximately 11.6 kilometers downstream from the Middle Basin WWTF. Results from a previous study indicated that wastewater effluent has a substantial effect on nutrient concentrations in Indian Creek. To better characterize the spatiotemporal variability of nutrients in Indian Creek, the U.S. Geological Survey, in cooperation with the Kansas Department of Health and Environment and Johnson County Wastewater, collected high-resolution spatial data (a large number of samples collected over the entire reach or at single locations over a long period of time) using a combination of discrete samples and sensor-measured data from 2013 to 2015. These spatial data provided insights into nutrient transport downstream from the Middle Basin WWTF, and allowed a more comprehensive temporal analysis of continuously measured nitrate data collected at six Indian Creek and Tomahawk Creek sites from March 2012 through June 2013.

The purpose of this report is to describe inorganic nutrient (nitrate plus nitrite and orthophosphorus) variability in Indian Creek, Johnson County, Kansas, using spatially and temporally dense data collected from March 2012 through August 2015. Two intensive spatial studies performed during summers 2014 and 2015 included sensor-measured nitrate plus nitrite data and collection of discrete orthophosphorus samples. Two additional spatial studies in 2013 and 2015 collected sensor-measured nitrate plus nitrite data. Sensormeasured nitrate plus nitrite data collected every 15 minutes during March 2012 through June 2013 were used to describe spatial and temporal (cyclical and seasonal) variability in concentrations. The high-resolution spatial data provided insight about the effect of the Middle Basin WWTF on Indian Creek nitrate plus nitrite concentrations and informed the analysis of the high-resolution temporal data collected during March 2012 through June 2013.

The spatiotemporal variability of nutrients in Indian Creek was characterized using a combination of floatingsensor arrays, discrete samples, and fixed-site sensors along a 16-kilometer $(\mathrm{km})$ reach of Indian Creek, including two wastewater treatment facilities (Middle Basin, Tomahawk Creek) and five tributaries. Six of the sites were included in the 2011-13 study, and serve as a frame of reference for all other sites included in the current (2016) study. Five of the sites were located on Indian Creek and one site was located on Tomahawk Creek, the largest tributary to Indian Creek. The 119th and Tomahawk sites were located upstream from the Middle Basin and Tomahawk Creek WWTF effluent discharges. The College, Marty, and Mission Farms sites are located 1.1, 5.5, and $9.8 \mathrm{~km}$, respectively, downstream from the Middle Basin WWTF effluent discharge. The State Line site is located $13.6 \mathrm{~km}$ downstream from the Middle Basin WWTF effluent discharge and $2.0 \mathrm{~km}$ downstream from the Tomahawk Creek WWTF effluent discharge.

Four spatially dense longitudinal surveys were performed on Indian Creek during 2013-15, and included a combination of fixed-site sensors, floating-sensor arrays, and discrete sample collection. Surveys were performed over a range of below normal to slightly above-normal streamflow conditions, with wastewater effluent contributing from 38 to 100 percent of total streamflow. Sensor-measured nitrate data were collected every 15 minutes at six fixed-sites from March 2012 through June 2013. The sensor-measured nitrate data were used to describe spatial and temporal (cyclical and seasonal) variability in nitrate concentrations.

The cyclical variability in nitrate concentrations in the Middle Basin WWTF effluent substantially affected the spatiotemporal patterns observed in Indian Creek during the longitudinal surveys and at the fixed-site locations. Nitrate concentrations in the Middle Basin WWTF effluent and at downstream sites varied by as much as 6 milligrams per liter over a 24-hour period. The cyclical variability in Middle Basin effluent generated a nitrate pulse that could be tracked for approximately $11.5 \mathrm{~km}$ downstream in Indian Creek, until the effect was masked by the Tomahawk Creek WWTF effluent discharge.

All four of the spatially dense longitudinal surveys showed the same general patterns along the upstream-downstream gradient, though streamflows, effluent contributions to streamflow, and nutrient concentrations spanned a wide range. With the exception of Tomahawk Creek, tributaries contributed small amounts of flow and nutrients to Indian Creek. Nutrient patterns observed along the upstream-downstream gradient were largely affected by the WWTFs and the travel time of the parcels of water. In all surveys, nitrate concentrations initially decreased downstream from the Middle Basin WWTF, increased to a peak somewhere upstream from the Marty site, and decreased at varying rates to downstream minima at the confluence with Tomahawk Creek. Nitrate concentrations increased immediately downstream from the Tomahawk Creek WWTF and either decreased or varied little to the State Line site. The nitrate peaks encountered upstream from the Marty site reflect peaks in nitrate concentrations that occurred approximately 24 hours before arrival at the Middle Basin WWTF. The magnitude and location of the nitrate peaks upstream from the Marty site depended on the 
peak concentrations observed at the Middle Basin WWTF and the time of day the surveys were performed. The patterns and rates of change in nitrate concentrations downstream from the Marty site reflect peaks in nitrate concentrations that occurred approximately 48 to 72 hours before at the Middle Basin WWTF.

Differences in orthophosphorus and nitrate patterns were clear along the upstream-downstream gradient in Indian Creek, and orthophosphorus concentrations were not as variable as nitrate. In general, orthophosphorus concentrations decreased downstream from the Middle Basin WWTF to minima near the confluence with Tomahawk Creek, increased downstream from the Tomahawk Creek WWTF, and then remained varied little to the State Line site. Tomahawk Creek indicated a clear dilution effect on nitrate concentrations, but not orthophosphorus concentrations in Indian Creek. Orthophosphorus was not measured at the same spatial resolution as nitrate (every 0.5 to $1.0 \mathrm{~km}$ compared to sensor measurements at 30 -second intervals), and temporal variability was not quantified. Therefore, some of the differences in observed patterns may be due to differences in the way the two nutrients were measured. Differences also may be due to differences in the treatment processes for the two nutrients and differences in biological and other in-stream processing of the two nutrients.

Despite the marked variability in nitrate concentrations caused by the WWTF, patterns of decreasing nitrate concentrations were discernable along the upstream-downstream gradient using the fixed-site data collected from March 2012 through June 2013. Tracking pulse peaks (maxima) in nitrate concentration downstream allowed quantification of decreases in the same general parcel of water over time. Decreases in nitrate concentrations along the $8.7-\mathrm{km}$ study reach between the College and Mission Farms sites were less variable than the cyclical variability typically measured along the same reach, reiterating the effect of the Middle Basin WWTF on the spatiotemporal variability of nitrate in Indian Creek.

On average, maximum nitrate concentrations decreased by about 2.3 milligrams per liter between the College and Mission Farms sites. Initial nitrate concentration was positively correlated with decreases, indicating that higher initial concentrations resulted in greater decreases. For the College to Mission Farms reach, decreases in nitrate concentration were generally consistent across seasons. By comparison, although decreases and rates of change in nitrate concentration were similar between the upper (College to Marty) and lower (Marty to Mission Farms) reaches, relations with initial nitrate concentrations and seasonal patterns were different between the two reaches and did not reflect patterns observed for the overall reach. Quantifying the decreases in nitrate concentration caused by dilution and other in-stream processes were beyond the scope of this study, and limited by available data. The data that are available suggest that dilution and other in-stream processes play a role in decreasing nitrate concentrations in Indian Creek downstream from the Middle Basin WWTF.
Analysis of the spatiotemporal variability of nutrients focused on below-normal and normal streamflow conditions, when streamflow and nutrient conditions in Indian Creek were largely controlled by WWTF effluent flows and nutrient removal processes. Spatial and temporal data indicate there are decreases in nutrient concentrations along the upstream-downstream gradient in Indian Creek, but quantifying decreases is complicated by the variability in nutrient concentrations caused by the WWTFs. During below-normal and normal streamflow conditions, Indian Creek nutrient concentrations downstream from the Middle Basin WWTF primarily reflect effluent concentrations in the hours or days before depending on relative distance downstream.

\section{References Cited}

Allan, J.D., 1995, Stream ecology-Structure and function of running waters: Boston, Mass., Kluwer Academic Publishers, 388 p.

American Public Health Association, American Water Works Association, and Water Environment Federation, 2005, Standard methods for the examination of water and wastewater (21st ed.): Washington D.C., American Public Health Association, $1368 \mathrm{p}$.

Dodds, W.K., Jones, J.R., and Welch, E.B., 1998, Suggested classification of stream trophic state: distributions of temperate stream types by chlorophyll, total nitrogen, and phosphorus: Water Research, v. 32, p. 1455-1462.

Esri, 2016, ArcGIS for desktop documentation: Esri, accessed October 2016, at http://desktop.arcgis.com/en/documentation/.

Graham, J.L., Stone, M.L., Rasmussen, T.J., Foster, G.M., Poulton, B.C., Paxson, C.R., and Harris, T.D., 2014, Effects of wastewater effluent discharge and treatment facility upgrades on environmental and biological conditions of Indian Creek, Johnson County, Kansas, June 2004 through June 2013: U.S. Geological Survey Scientific Investigations Report 2014-5187, 78 p.

Heffernan, J.B., and Cohen, M.J., 2010, Direct and indirect coupling of primary production and diel nitrate dynamics in a subtropical spring-fed river: Limnology and Oceanography, v. 55, no. 2 , p. 677-688.

Henze, M., Harremoës, P., la Cour Jansen, J., and Arvin, E., 2002, Wastewater treatment, biological and chemical processes, (3rd ed.): Springer, $422 \mathrm{p}$.

Kansas Department of Health and Environment, 2004, Surface water nutrient reduction plan: Topeka, Kansas, Bureau of Water, $47 \mathrm{p}$. 
King, L.R., Foster, G.M., and Graham, J.L., 2016a, Spatial water-quality data for Indian Creek, Johnson County, Kansas, May 23, 2013, July 23, 2014, July 30, 2015 and August 26, 2015: U.S. Geological Survey data release, https://dx.doi.org/10.5066/F77W69CP.

King, L.R., Foster, G.M., and Graham, J.L., 2016b, Waterquality data from four Indian Creek Sites, Johnson County, Kansas, July 22-25, 2014 and August 21-27, 2015: U.S. Geological Survey data release, https://dx.doi.org/10.5066/ F7445JN8.

Mulholland, P.J., Fellows, C.S., Tank, J.L., Grimm, N.B., Webster, J.R., Hamilton, S.K., Marti, E., Ashkenas, L., Bowden, W.B., Dodds, W.K., McDowell, W.H., Paul, M.J., and Peterson, B.J., 2001, Inter-biome comparison of factors controlling stream metabolism: Freshwater Biology, v. 46, p. $1503-1517$.

Pellerin, B.A., Downing, B.D., Kendall, C., Dahlgren, R.A., Kraus, T.E, Saraceno, J.F., Spencer, R.G.M., and Bergamaschi, B.A., 2009, Assessing the sources and magnitude of diurnal nitrate variability in the San Joaquin River (California) with an in situ optical nitrate sensor and dual nitrate isotopes: Freshwater Biology, v. 54, p. 376-387.

Pellerin, B.A., Bergamaschi, B.A., Downing, B.D., Saraceno, J.F., Garrett, J.A., and Olsen, L.D., 2013, Optical techniques for the determination of nitrate in environmental watersGuidelines for instrument selection, operation, deployment, maintenance, quality assurance, and data reporting: U.S. Geological Survey Techniques and Methods, book 1, chap. D5, $37 \mathrm{p}$.

Rasmussen, T.J., and Gatotho, J., 2014, Water-quality variability and constituent transport and processes in streams of Johnson County, Kansas, using continuous monitoring and regression models, 2003-11: U.S. Geological Survey Scientific Investigations Report 2013-5221, 64 p.

Rasmussen, T.J., Poulton, B.C., and Graham, J.L., 2009, Quality of streams in Johnson County, Kansas, and relations to environmental variables, 2003-07: U.S. Geological Survey Scientific Investigations Report 2009-5235, 95 p.

Rasmussen, T.J., Stone, M.L., Poulton, B.C., and Graham, J.L., 2012, Quality of streams in Johnson County, Kansas, 2002-10: U.S. Geological Survey Scientific Investigations Report 2012-5279, 103 p.

Sauer, V.B., and Turnipseed, D.P., 2010, Stage measurement at gaging stations: U.S. Geological Survey Techniques and Methods, book 3, chap. A7, 45 p. [Also available at http:// pubs.usgs.gov/tm/tm3-a7/.]

Tchobanoglous, G., Burton, F.L., and Stensel, H.D., 2003, Wastewater engineering, treatment and reuse (4th ed.): Boston, McGraw-Hill, 1,819 p.
Turnipseed, D.P., and Sauer, V.B., 2010, Discharge measurements at gaging stations: U.S. Geological Survey Techniques and Methods, book 3, chap. A8, 87 p. [Also available at http://pubs.usgs.gov/tm/tm3-a8/.]

U.S. Environmental Protection Agency, 2009, National water quality inventory: Report to Congress, Washington, D.C., U.S. Environmental Protection Agency, Office of Water, EPA 841-R-08-001, [variously paged], accessed July 2013 at http://water.epa.gov/lawsregs/guidance/ cwa/305b/2004report_index.cfm.

U.S. Geological Survey, variously dated, National field manual for the collection of water-quality data: U.S. Geological Survey Techniques of Water-Resources Investigations, book 9, chaps. A1-A10. [Also available at http://pubs.water. usgs.gov/twri9A.]

U.S. Geological Survey, 2014, USGS WaterWatch: Web site accessed September 2014 at http://waterwatch.usgs.gov.

Wagner, R.J., Boulger, R.W., Jr., Oblinger, C.J., and Smith, B.A., 2006, Guidelines and standard procedures for continuous water-quality monitors - Station operation, record computation, and data reporting: U.S. Geological Survey Techniques and Methods, book 1, chap. D3, 96 p.

Welch, E.B., and Lindell, T., 1992, Ecological effects of wastewater (2d ed.): London, Spon Press, 425 p.

Yellow Springs Instruments (YSI), 2014, EXO user manual: advanced water quality monitoring platform, Revision D, $156 \mathrm{p}$.

Zar, J.H., 1999, Biostatistical analysis (4th ed.): New Jersey, Prentice-Hall Inc., 663 p. 


\section{Appendixes 1-4}

Appendixes 1 through 4 are available for download at http://dx.doi.org/10.3133/sir20165147 
Publishing support provided by: Rolla Publishing Service Center

For additional information concerning this publication, contact: Director, USGS Kansas Water Science Center

4821 Quail Crest Place

Lawrence, KS 66049

(785) 842-9909

Or visit the Kansas Water Science Center Web site at: http://ks.water.usgs.gov 
Back cover photographs. U.S. Geological Survey hydrologist collecting spatial data on Indian Creek, July 23, 2014 (photograph by J. Gonzalez, U.S. Geological Survey); top left, fixed waterquality instrumentation at Indian Creek at Overland Park, Kansas, July 23, 2014 (photograph by G. Foster, U.S. Geological Survey); middle left, fixed water-quality instrumentation above Middle Basin wastewater treatment facility, Kansas, July 23, 2014 (photograph by G. Foster, U.S. Geological Survey); bottom left, fixed water-quality instrumentation at Middle Basin wastewater treatment facility effluent discharge, Kansas, July 23, 2014 (photograph by G. Foster, U.S. Geological Survey). 
